Nevada

Environmental

Restoration

Project

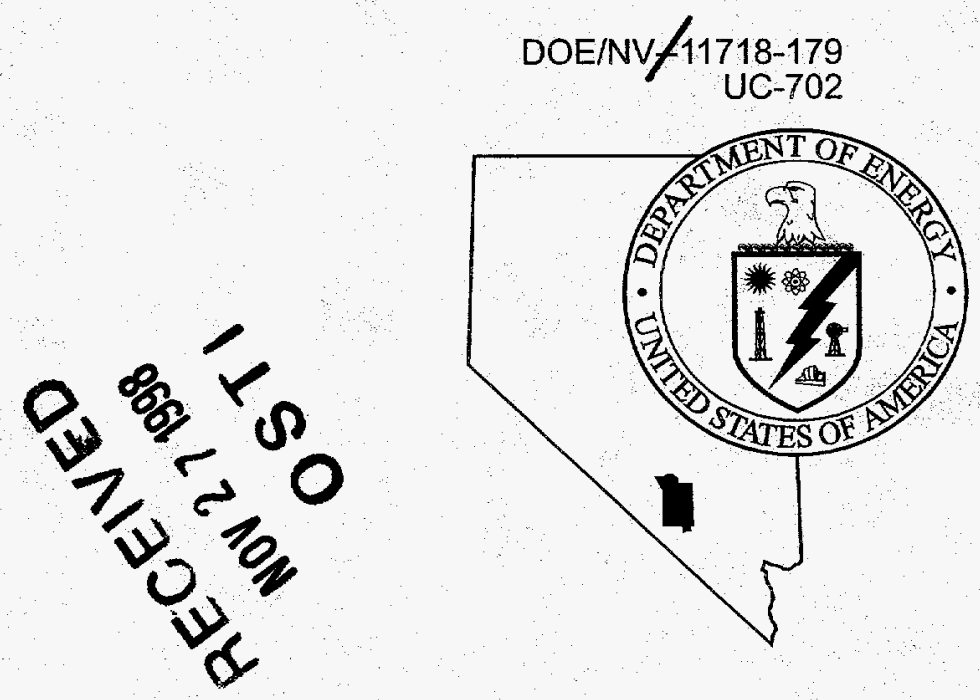

\title{
Closure Report for CAU No. 416 Project Shoal Area
}

\section{UNCONTROLLED COPY}

Controlled Copy No.

Revision: 0

DISTREUTION OF THIS DOCUMENT IS UNLLMTED

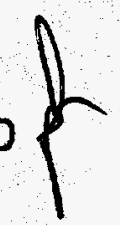

January 1998

Environmental Restoration

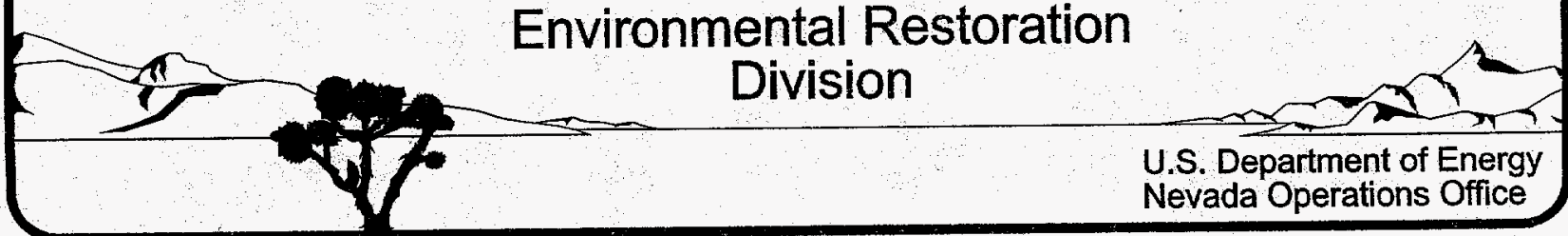


This report has been reproduced from the best available copy.

DOE and DOE contractors can obtain copies of this report from the Office of Scientific and Technical Information; P.O. Box 62, Oak Ridge, TN 37831, (423) 576-8401.

This report is available to the public from the National Technical Information Service, U. S. Department of Commerce, 5285 Port Royal Road, Springfield, VA, 22161, (703) 487-4650. 


\section{DISCLAIMER}

This repor was prepared as an account of work sponsored by an agency of the United States Government. Neither the United States Government nor any agency thereof, not any of their employees, makes any warranty, express or implied, or assumes any legal liability or responsibility for the acenracy, completereas, or usefulness of any information, apparatus, produch, or process disclosed, or represents that its use would not infringe privately owaed rights. Reference herein to any specific commercial product, process, or service by trade name, trademarte tmanufacturet, or otherwise does not necessarily constimte or imply its endorsemeat, recommenditioa, or favoring by the Uaited States Government or any agency thereof. The views and opinions of authors expresced herein do not necessarily state or reflect those of the. United States Goverament or any agency thereof. 


\section{DISCLAIMER}

Portions of this document may be illegible in electronic image products. Images are produced from the best available original document. 


\title{
CLOSURE REPORT FOR CAU 416: PROJECT SHOAL AREA
}

\author{
Prepared for \\ U. S. Department of Energy \\ Nevada Operations Office \\ Under Contract No. DE-AC08-96NV11718
}

\section{UNCONTROLLED COPY}

Controlled Copy No.:

Revision: 0

Prepared by

Bechtel Nevada

Environmental Restoration Program

January 1998 


\section{CLOSURE REPORT FOR CAU 416: PROJECT SHOAL AREA}

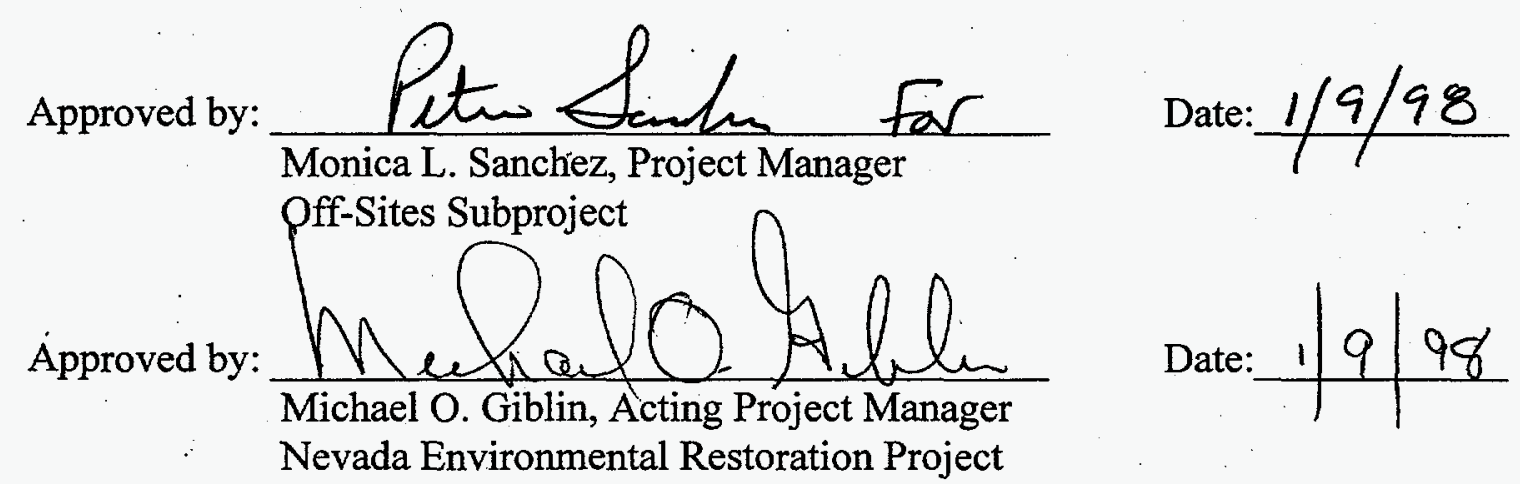




\section{TABLE OF CONTENTS}

ACRONYMS AND ABBREVIATIONS $\ldots \ldots \ldots \ldots \ldots \ldots \ldots \ldots \ldots \ldots \ldots$ ii

EXECUTIVE SUMMARY

$\mathrm{v}$

1.0 INTRODUCTION $\ldots \ldots \ldots \ldots \ldots \ldots \ldots \ldots \ldots \ldots \ldots \ldots \ldots \ldots \ldots \ldots \ldots \ldots$

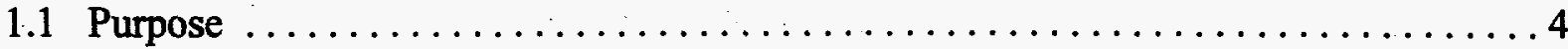

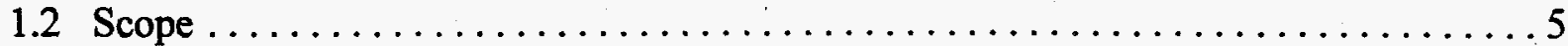

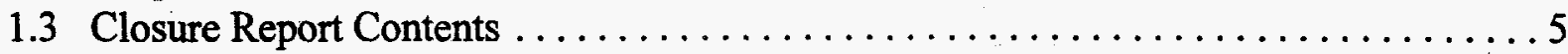

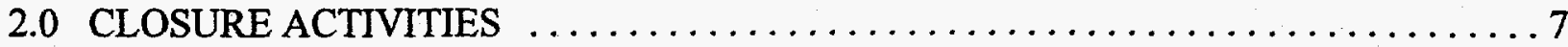

2.1 Description of Corrective Action Activities $\ldots \ldots \ldots \ldots \ldots \ldots \ldots \ldots \ldots \ldots \ldots$

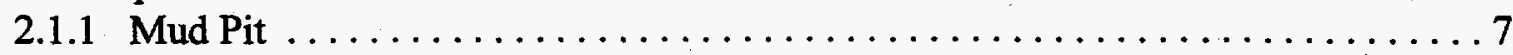

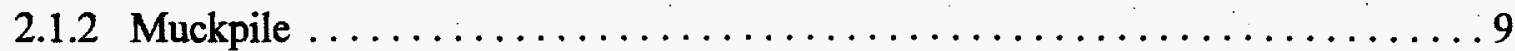

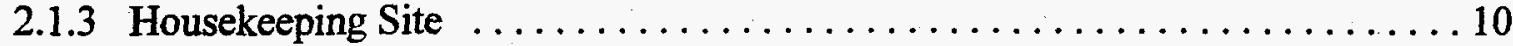

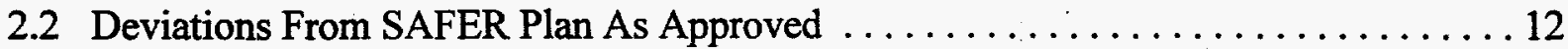

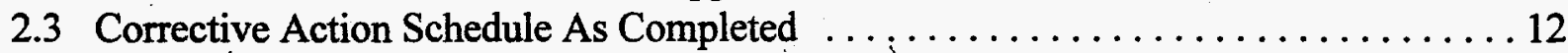

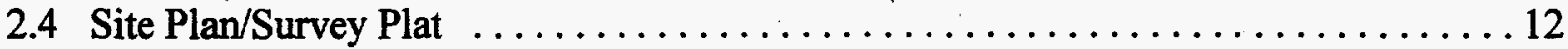

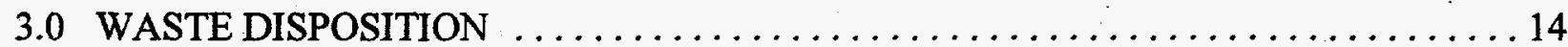

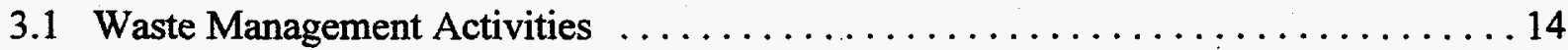

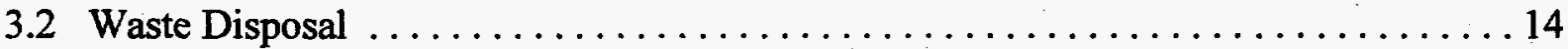

4.0 CLOSURE VERIFICATION RESULTS $\ldots \ldots \ldots \ldots \ldots \ldots \ldots \ldots \ldots \ldots \ldots \ldots \ldots$

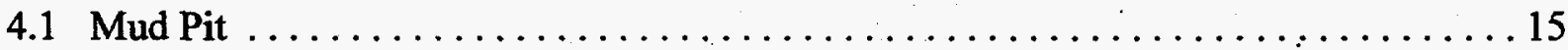

4.1.1 First Phase of Verification Sampling/Analysis $\ldots \ldots \ldots \ldots \ldots \ldots \ldots \ldots$

4.1.2 Second Phase of Verification Sampling/Analysis $\ldots \ldots \ldots \ldots \ldots \ldots \ldots \ldots$

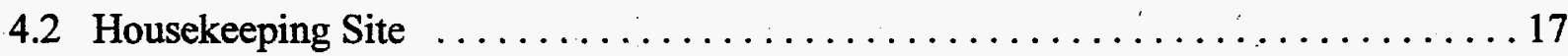

5.0 CONCLUSIONS AND RECOMMENDATIONS $\ldots \ldots \ldots \ldots \ldots \ldots \ldots \ldots \ldots \ldots$

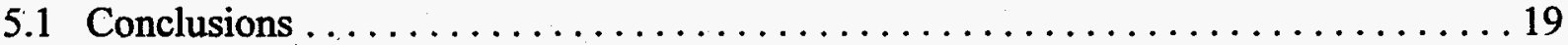

5.2 Recommendations ................................ 19

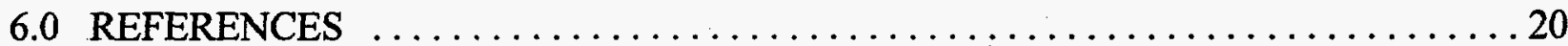




\section{TABLE OF CONTENTS (continued)}

\section{FIGURES}

FIGURE 1 - LOCATION OF PROJECT SHOAL AREA $\ldots \ldots \ldots \ldots \ldots \ldots \ldots \ldots \ldots$

FIGURE 2 - PROJECT SHOAL AREA SITE MAP $\ldots \ldots \ldots \ldots \ldots \ldots \ldots \ldots \ldots$

FIGURE 3 - MUD PIT SAMPLING LOCATIONS AND EXCAVATION AREA $\ldots \ldots \ldots . .8$

FIGURE 4 - CORRECTIVE ACTION SCHEDULE AS COMPLETED . . . . . . . . 13

\section{TABLES}

TABLE 1 - SAMPLE ANALYTICAL RESULTS, GRANITE SAMPLES

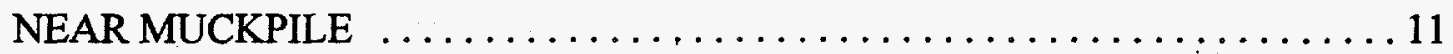

TABLE 2 - SAMPLE ANALYTICAL RESULTS, FIRST PHASE OF

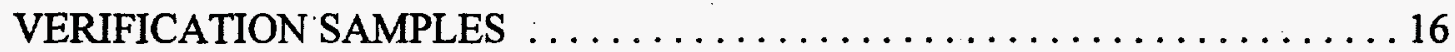

TABLE 3 - SAMPLE ANALYTICAL RESULTS, SECOND PHASE OF VERIFICATION SAMPLES

\section{APPENDICES}

APPENDIX A - Laboratory Analytical Results, Granite Samples Near Muckpile

APPENDIX B - Housekeeping Site Closure Verification Documentation

APPENDIX C - Waste Disposal Documentation

APPENDIX D - Laboratory Analytical Results, Mud Pit Verification Samples 


\section{ACRONYMS AND ABBREVIATIONS}

\begin{tabular}{|c|c|}
\hline $\mathrm{AEC}$ & U.S. Atomic Energy Commission \\
\hline CAS & Corrective Action Site \\
\hline $\mathrm{CAU}$ & Corrective Action Unit \\
\hline $\mathrm{COC}$ & Constituent of Concern \\
\hline CR & Closure Report \\
\hline $\mathrm{DOE} / \mathrm{NV}$ & U.S. Department of Energy, Nevada Operations Office \\
\hline FFACO & Federal Facilities Agreement and Compliance Order \\
\hline $\mathrm{ft}$ & feet \\
\hline $\mathrm{ft}^{2}$ & square feet \\
\hline gal & gallon \\
\hline in & inch \\
\hline $\mathrm{km}$ & kilometer \\
\hline $\mathrm{L}$ & liter \\
\hline $\mathrm{m}$ & meter \\
\hline $\mathrm{m}^{2}$ & square meter \\
\hline $\mathrm{m}^{3}$ & cubic meter \\
\hline $\mathrm{mg} / \mathrm{kg}$ & milligrams per kilogram \\
\hline $\mathrm{mi}$ & mile \\
\hline NDEP & Nevada Division of Environmental Protection \\
\hline NTS & Nevada Test Site \\
\hline
\end{tabular}




\section{ACRONYMS AND ABBREVIATIONS (continued)}

PSA Project Shoal Area

SAFER Streamlined Approach for Environmental Restoration

TPH Total Petroleum Hydrocarbons

U.S. United States

$\mathrm{yd}^{3} \quad$ cubic yard 
This Closure Report provides the documentation for closure of the United States Department of Energy/Nevada Operations Office (DOE/NV) Project Shoal Area (PSA) Surface Corrective Action Unit (CAU) 416. CAU 416 consists of a mud pit (Corrective Action Site [CAS] 57-0901), muckpile (CAS 57-06-01), and housekeeping site (CAS 57-98-01). The PSA is located approximately 48.3 kilometers ( 30 miles) southeast of Fallon, Nevada.

The closure of the PSA CAU 416 has been completed in accordance with the Nevada Division of Environmental Protection approved Streamlined Approach For Environmental Restoration Plan For Corrective Action Unit 416. Mud Pit. Project Shoal Area (DOE, 1997a), Record of Technical Change No. 1 For Streamlined Approach For Environmental Restoration Plan For Corrective Action Unit 416. Mud Pit. Project Shoal Area (DOE, 1997b), and Housekeeping Category Corrective Action Unit Workplan (DOE, 1996).

The mud pit was the result of drilling activities at the PSA in 1963. Investigation activities completed in 1996 determined drilling mud in the mud pit was impacted with petroleum hydrocarbons in excess of the State of Nevada 100 milligram per kilogram $(\mathrm{mg} / \mathrm{kg})$ Total Petroleum Hydrocarbon (TPH) Action Level (NAC, 1996). The mud pit closure activities consisted of excavation, transportation, and disposal of approximately 184 cubic meters $\left(\mathrm{m}^{3}\right)$ ( 240 cubic yards $\left.\left[\mathrm{yd}^{3}\right]\right)$ of petroleum hydrocarbon impacted drilling mud and weathered granite, verification sampling and analysis, and regrading of the mud pit area. The impacted materials were disposed of in the Area 6 Hydrocarbon Landfill located at the Nevada Test Site (NTS). The verification samples collected from the bottom of the excavation area indicate the materials. exceeding the Action Level were successfully removed.

The muckpile consists of broken granite from emplacement shaft and drift (tunnel) mining activities at the PSA in 1963. Approximately $5,000 \mathrm{~m}^{3}\left(6,535 \mathrm{yd}^{3}\right)$ of broken granite is stockpiled at the surface in an area of approximately 930 square meters $(10,000$ square feet). Analytical results of samples collected in weathered granite approximately 274 meters (m) $(900$ feet [ft]) northeast of the muckpile indicate constituents of concern (COC's) do not exceed regulatory action levels. Geological data from a site report (DRI, 1988) indicates the granite removed from the emplacement shaft and drift is similar in composition from the surface to the maximum depth of the shaft $(402 \mathrm{~m}[1,320 \mathrm{ft}])$.

The housekeeping site consisted of approximately 20 used, empty, rusted, steel 0.9 liter (1 quart) oil cans. The oil cans were potentially from the site activities in the 1960 's based upon the construction material and style of can. The cans were removed from the site and disposed of the Area 23 Landfill located at the NTS.

The DOE/NV requests the Nevada Division of Environmental Protection to issue a Notice of Completion and move the Project Shoal Area Surface CAU 416 (CAS 57-09-01, CAS 57-06-01, and CAS 57-98-01) from Appendix III to Appendix IV of the Federal Facility Agreement and 
Consent Order because the following corrective action activities were completed as proposed:

- The impacted materials exceeding the $100 \mathrm{mg} / \mathrm{kg}$ TPH Action Limit were removed and properly disposed of from the mud pit (CAS 57-09-01).

- The process knowledge (analytical results from the weathered granite samples and site geological data) indicates no COC's exceed regulatory levels in the muckpile (CAS 5706-01).

- The housekeeping site (CAS 57-98-01) was remediated. 


\subsection{INTRODUCTION}

The U.S. Department of Energy, Nevada Operations Office (DOE/NV) operates the Nevada Test Site (NTS) and entered into a trilateral agreement with the state of Nevada and the U.S. Defense Special Weapons Agency. The trilateral agreement, which is entitled the Federal Facilities Agreement and Consent Order (FFACO), provides a framework for identifying, characterizing, remediating, and closing DOE/NV environmental sites in Nevada (NDEP, 1996). Two Corrective Action Units (CAUs) are identified for the DOE/NV Project Shoal Area (PSA) in the FFACO (CAU 416 and CAU 447). The PSA Surface is identified as CAU 416, and the PSA Subsurface is identified as CAU 447.

This Closure Report (CR) provides the documentation for the Streamlined Approach for Environmental Restoration (SAFER) closure of the PSA Surface CAU 416. The PSA is located approximately 48.3 kilometers $(\mathrm{km})(30$ miles [mi]) southeast of Fallon, Nevada, in the Sand Springs Range of Churchill County (see Figure 1). CAU 416 consists of a mud pit (Corrective Action Site [CAS] 57-09-01), muckpile (CAS 57-06-01), and housekeeping site (CAS 57-98-01).

Project Shoal was part of the Vela Uniform Program, a U.S. Department of Defense and U.S. Atomic Energy Commission (AEC) study to evaluate the effects of different geologic media (e.g., granite) on seismic waves produced by underground nuclear tests and to determine whether seismic waves from underground nuclear tests could be differentiated from seismic waves from naturally occurring earthquakes (DRI, 1988).

The Shoal event was a 12.5-kiloton device detonated on October 26, 1963. The device was placed in granite 369 meters (m) (1,211 feet [ft]) below the ground surface (DOE, 1997a). Emplacement of the device was accomplished by mining an approximate $3.6 \mathrm{~m}(12 \mathrm{ft})$ by $1.8 \mathrm{~m}$ $(6 \mathrm{ft})$ shaft to approximately $402 \mathrm{~m}(1,320 \mathrm{ft})$. A drift (tunnel) was mined from the shaft approximately $320 \mathrm{~m}(1,050 \mathrm{ft}$ ) to the east (AEC, 1970). The muckpile (CAS 57-06-01) was the result of stockpiling the broken granite from the mining activities associated with the construction of the shaft. The muckpile is located approximately $46 \mathrm{~m}(150 \mathrm{ft})$ east of the shaft (see Figure 2). The shaft was permanently closed in 1996 by backfilling with materials from the muckpile. Approximately 2,445 cubic meters $\left(\mathrm{m}^{3}\right)\left(3,200\right.$ cubic yards $\left.\left[\mathrm{yd}^{3}\right]\right)$ was used to backfill the shaft. Approximately $5,000 \mathrm{~m}^{3}\left(6,535 \mathrm{yd}^{3}\right)$ of broken granite remains at the surface in an area of approximately 930 square meters $\left(\mathrm{m}^{2}\right)\left(10,000\right.$ square $\left.\mathrm{ft}\left[\mathrm{ft}^{2}\right]\right)$.

The mud pit was constructed in a natural drainage area approximately $350 \mathrm{~m}(1150 \mathrm{ft})$ east of the emplacement shaft (Figure 2). The mud pit was used to contain drilling effluent and cuttings from the Post Shot Borehole PS-1 in 1963. During drilling activities for Post Shot Borehole PS$\mathrm{I}$, short-lived gaseous radionuclides (iodine-131, xenon $131 \mathrm{~m}$, and xenon-133) were brought to the surface through the drill rig effluent vent-line system (DOE, 1997a). The radionuclides were 


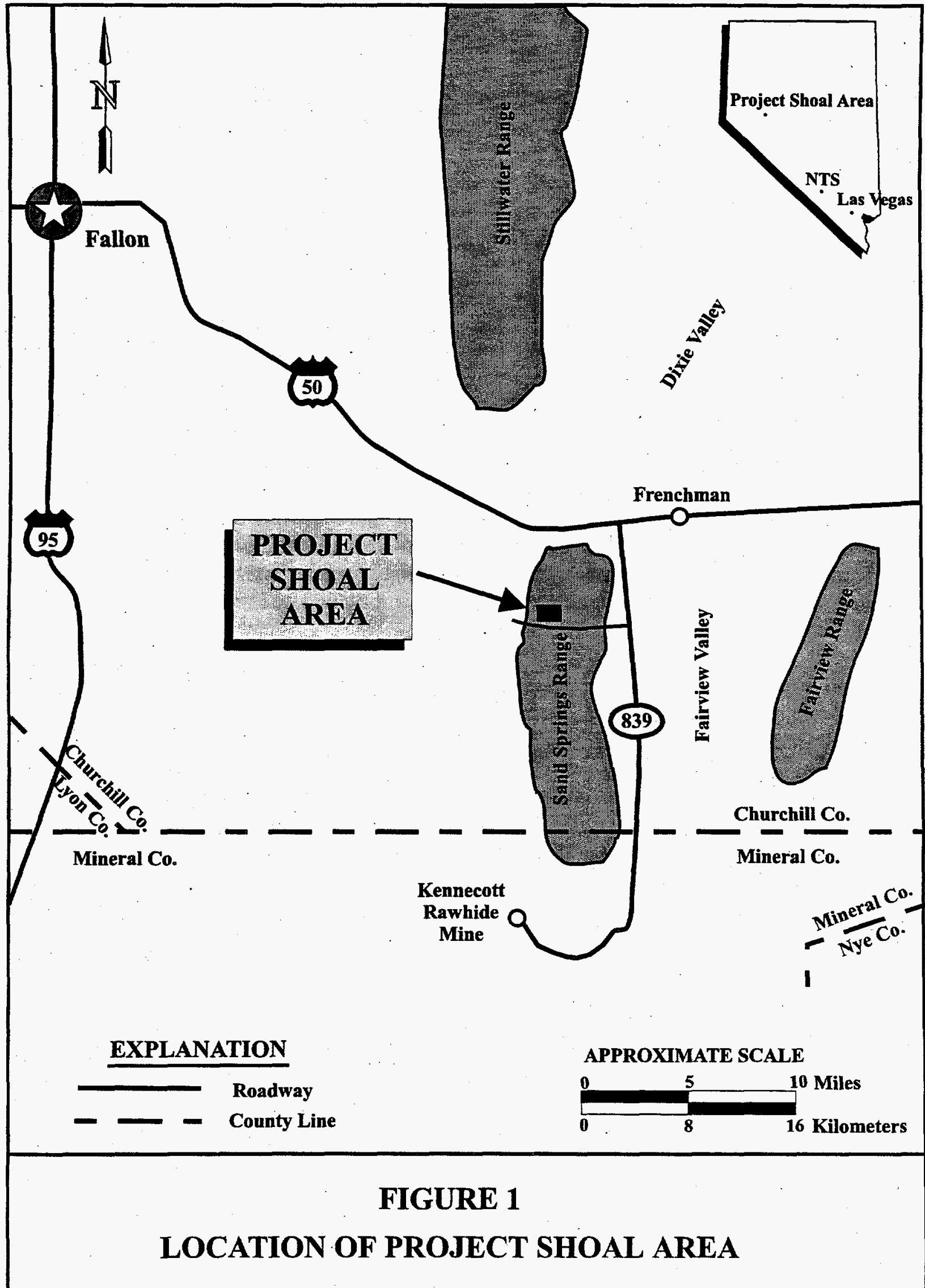




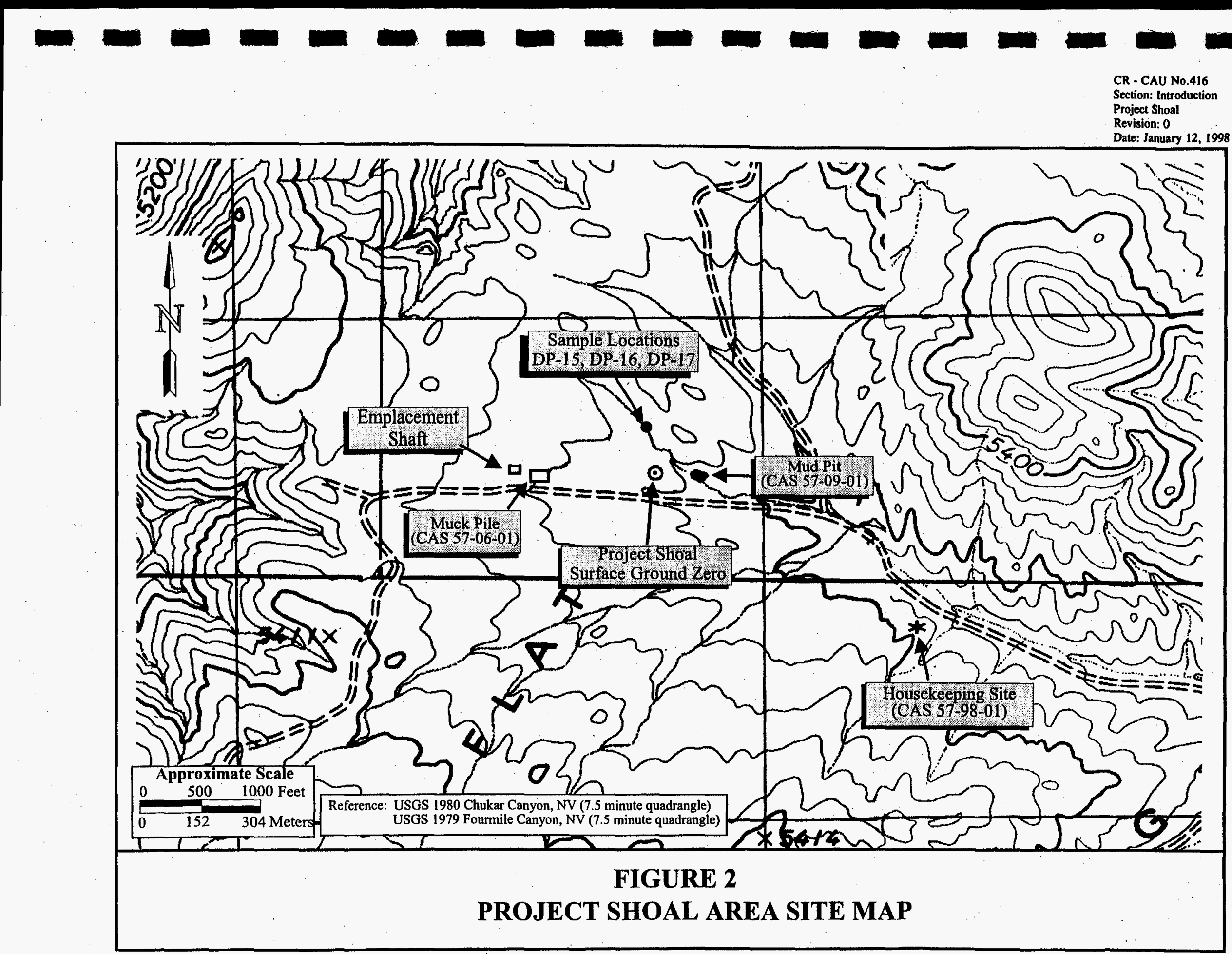


trapped by filters and were subsequently mixed with clean soil and buried in the mud pit (DOE, 1997a). Results from the 1996 characterization activities indicated that no radionuclides were detected above expected values for a granitic terrain; however, Total Petroleum Hydrocarbons (TPH) as diesel and oil were detected above the $100 \mathrm{mg} / \mathrm{kg}$ action level (NAC, 1996). The diesel and oil are suspected to have been used in the drilling mud. No other consitituents were detected exceeding regulatory limits (DOE, 1997a).

The housekeeping site is located approximately $701 \mathrm{~m}(2,300 \mathrm{ft})$ southeast of the mudpit (Figure 2). The housekeeping site consisted of approximately 20 used, empty, rusted, steel 0.9 liter (1 quart) oil cans. The oil cans were potentially from the site activities in the 1960's based upon the construction material and style of can.

DOE/NV proposed to close the mud pit by excavating and disposing of the TPH impacted materials which exceeded the 100 milligram per kilogram $(\mathrm{mg} / \mathrm{kg})$ Action Level (NAC, 1996) in July 1997 (DOE, 1997a). The process knowledge to support closure in-place of the muckpile by no further action was proposed to be added to the SAFER Closure Plan in a Record of Technical Change in September 1997 (DOE, 1997b). Remediation of the housekeeping site using the Housekeeping Site Work Plan (DOE, 1996) with the documentation for closure to be included in the CR was proposed on August 13, 1997 (DOE, 1997c).

The Nevada Division of Environmental Protection (NDEP) approved the proposed activities in the SAFER Closure Plan on August 5, 1997 (NDEP, 1997a). The Record of Technical Change (DOE, 1997b) and proposal to remediate the housekeeping site using the Housekeeping Site Work Plan (DOE, 1996) were recorded as approved on September 19, 1997 (NDEP, 1997b).

The Field closure activities began on August 17, 1997 and were completed on August 27, 1997.

\subsection{PURPOSE}

The purpose of this CR is to:

- $\quad$ provide the information collected during the closure activities as proposed in the SAFER Plan (DOE, 1997a), Record of Technical Change (DOE, 1997b), and Housekeeping Site Work Plan (DOE; 1996).

- Obtain a Notice of Completion from the NDEP.

- Recommend the movement of CAU 416 from Appendix III to Appendix IV of the FFACO. 


\subsection{SCOPE}

The following remedial actions implemented for the closure of the mud pit (CAS 57-09-01) were:

- Excavated and removed of impacted materials from the mud pit area which exceeded the $100 \mathrm{mg} / \mathrm{kg}$ TPH Action Level.

- $\quad$ Conducted verification sampling at the bottom of the excavation in the area of the mud pit to confirm TPH concentrations were below the $100 \mathrm{mg} / \mathrm{kg}$ Action Level.

- Transported and disposed of the excavated hydrocarbon impacted materials in the Area 6 Hydrocarbon Landfill located at the Nevada Test Site (NTS).

- $\quad$ Regraded the mud pit area using soil from the mud pit retention berm.

The scope of work for the muckpile (CAS 57-06-01) was to provide sufficient information to close the muckpile in-place with no further action. Remedial activities for the housekeeping site (CAS 57-98-01) consisted of removal and disposal of the debris (approximately 20 used steel oil cans). Closure activities and justifications for closure of the mud pit, muckpile, and housekeeping site are documented in the following sections and appendices.

\subsection{CLOSURE REPORT CONTENTS}

This CR is divided into the following sections:

- Section 1.0 - Introduction: Site background, purpose, scope, and report contents

- Section 2.0 - Closure Activities: Corrective action activities, deviations from SAFER Plan as approved, corrective action schedule as completed, and site plan

- Section 3.0 - Waste Disposition

- Section 4.0 - Closure Verification Results

- Section 5.0 - Conclusions

- Section 6.0 - References

- Appendix A - Laboratory Analytical Results, Granite Samples Near Muckpile

- Appendix B - Housekeeping Site Closure Verification Documentation

- Appendix C - Waste Disposal Documentation 
- Appendix D - Laboratory Analytical Results, Mud Pit Verification Samples

This report was developed using information and guidance from the following documents:

- CERCLA Preliminary Assessment of DOE's Nevada Operations Office Nuclear Weapons Testing Areas. Desert Research Institute, 1988.

- Corrective Action Investigation Plan for Project Shoal Area, CAU No. 416, DOE, 1996.

- Housekeeping Category Corrective Action Unit Workplan, Rev. 0, DOE, August 1996.

- Nevada Environmental Restoration Project. Health and Safety Plan. DOE, 1996.

- Nevada Environmental Restoration Project, Industrial Sites, Quality Assurance Project Plan. Nevada Test Site, Revision 1, DOE, 1996.

- Nevada Environmental Restoration Project. Project Management Plan, DOE, 1994.

- Record of Technical Change No. 1 For Streamlined Approach For Environmental Restoration Plan For Corrective Action Unit 416, Mud Pit, Project Shoal Area, Rev. 1, DOE, August 8, 1997.

- Streamlined Approach For Environmental Restoration Plan For Corrective Action Unit 416. Mud Pit, Project Shoal Area, Rev. 1, DOE, July 1997. 


\subsection{CLOSURE ACTIVITIES}

This section of the CR details the specific activities involved in the closure of the PSA mud pit (CAS 57-09-01), the process knowledge to support closure in-place of the muckpile (CAS 57-0601) with no further action, and the remedial activities to close the housekeeping site (CAS 57-9801). This section also includes the rationale for any deviations from the approved SAFER Plan (DOE, 1997a) and a detailed schedule of site activities as completed.

\subsection{DESCRIPTION OF CORRECTIVE ACTION ACTIVITIES}

\subsubsection{Mud Pit}

Prior to excavating the hydrocarbon impacted materials in the mud pit, a site clearance for excavation was obtained by reviewing As-Built Engineering Drawings and contacting "Call Before You Dig." Subsurface utilities were not identified in the area of the excavation activities.

All sample location stakes from the 1996 characterization activities were located at the site prior to excavation activities which facilitated demarcation of the excavation area in relation to the 1996 sample points. The soil was excavated to an approximate depth of $0.6 \mathrm{~m}(2.0 \mathrm{ft})$ to $0.9 \mathrm{~m}$ $(3.0 \mathrm{ft})$ in an approximate area of $250 \mathrm{~m}^{2}\left(2,700 \mathrm{ft}^{2}\right)$ between August 18, 1997 and August 25, 1997. A front end loader was used to excavate and stockpile the excavated material. A backhoe equipped with a bucket without excavating teeth was used to cut and scrape the bottom and edges of the excavation as a waste volume reduction activity. Confirmational sampling activities and analytical results are discussed in Section 4.0.

Two phases of excavation were required to remove the hydrocarbon impacted soils above the 100 $\mathrm{mg} / \mathrm{kg}$ TPH Action Level. The first phase of excavation consisted of removing approximately $0.6 \mathrm{~m}(2.0 \mathrm{ft})$ of hydrocarbon impacted drilling mud and weathered granite followed by verification sampling and analysis. A second phase of excavation was required in the approximate northern one-third to one-half of the excavation area based upon analytical results of samples collected from the base of the excavation on August 19, 1997 (Figure 3). During the second phase of excavation, an additional approximate $0.3 \mathrm{~m}(1 \mathrm{ft})$ was removed and placed in the soil stockpile area as described previously.

All excavated soil was stockpiled approximately $30 \mathrm{~m}(100 \mathrm{ft})$ south of the mud pit (adjacent to the site access road) on two layers of $10 \mathrm{mil}(0.01 \mathrm{inch}$ [in]) plastic. At the end of each excavation day, the excavated soil was covered with 10 mil $(0.01 \mathrm{in})$ plastic and weighted on the edges for stabilization and management purposes. 


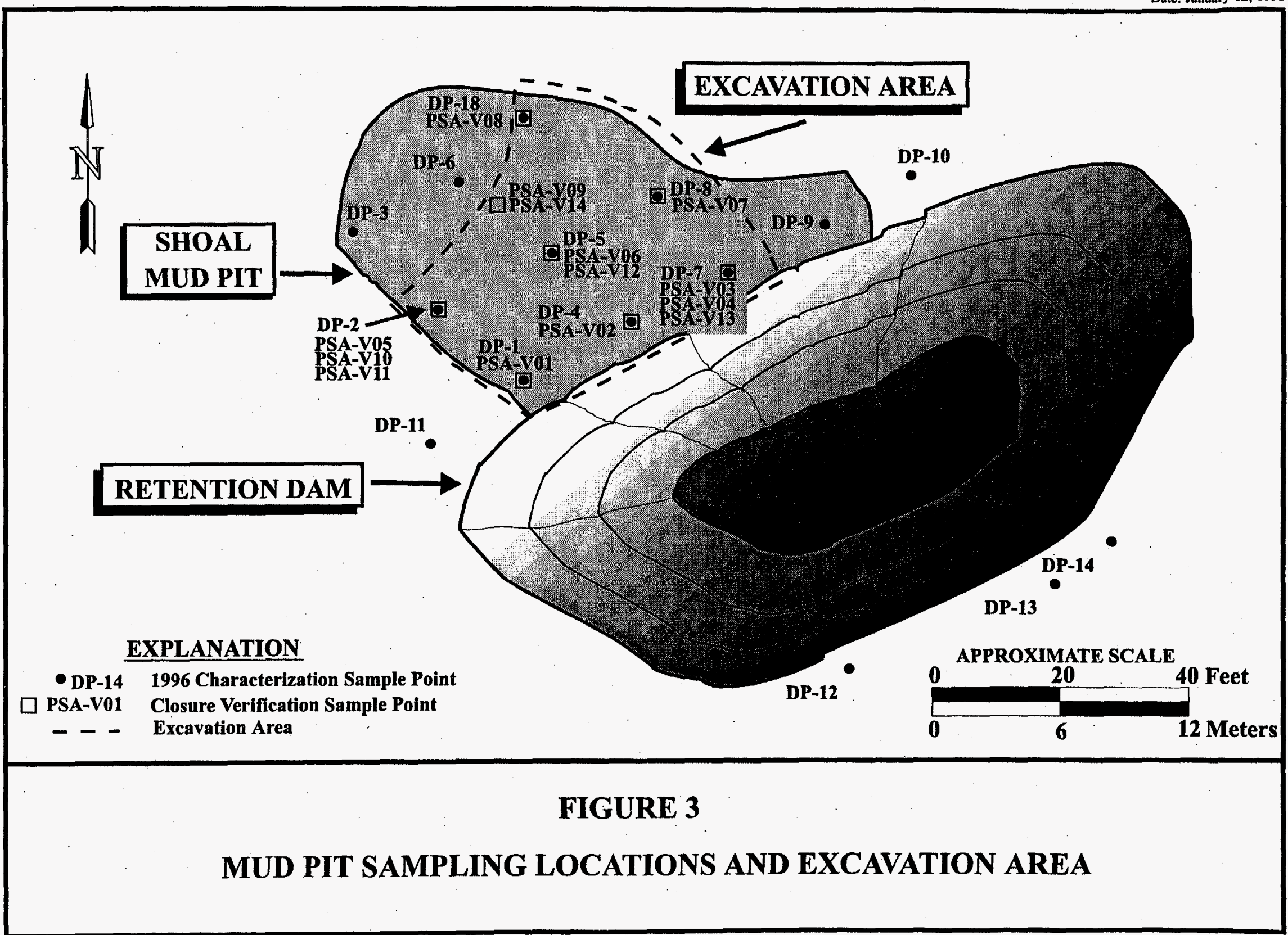


The excavation equipment buckets were cleaned after completion of the excavation and loading activities. Site personnel used brooms and hand sprayers containing Alconox ${ }^{\mathrm{TM}}$ and tap water to clean the equipment buckets. Approximately 7.6 liters.(L) (2 gallons [gal]) of water was used to clean the equipment. The cleaning activities were conducted over the final end-dump truck loaded with the hydrocarbon impacted soil excavated from the mud pit area. The final end-dump truck contained approximately $15.3 \mathrm{~m}^{3}\left(20 \mathrm{yd}^{3}\right)$ of impacted soil. For the discussion regarding waste management and disposal, see Section 3.0.

On August 27, 1997, analytical results were received indicating TPH concentrations were below the $100 \mathrm{mg} / \mathrm{kg}$ Action Level at all sample locations. Upon receipt of the results, the retention dam located on the south side of the mud pit was removed and used for backfill in the mud pit area. The area was graded as proposed in the SAFER Plan (DOE, 1997a). The area immediately south of the retention dam was regraded to blend with the adjacent topography.

Water for dust suppression activities associated with the excavation and regrading activities was obtained from the City of Fallon through Stockman's Equipment in Fallon, Nevada and the Kennecott Rawhide Mine located approximately $11.3 \mathrm{~km}(7 \mathrm{mi})$ south of the site (Figure 1). Approximately 15,140 L (4,000 gal) of water were used at the site. Dust suppression was accomplished through the use of the spray bars and hose on the water truck.

\subsubsection{Muckpile}

The PSA muckpile (CAS 57-06-01) consists of broken granite removed from the subsurface during the mining (construction) of the emplacement shaft and drifts (tunnels) in 1963. The broken granite was placed on the existing sloping topographic surface with a maximum relief from natural grade of approximately $5.5 \mathrm{~m}(18 \mathrm{ft})$ on the eastern perimeter. The muckpile tapers to meet natural grade on the western perimeter.

In 1996 , approximately $2,445 \mathrm{~m}^{3}\left(3,200 \mathrm{yd}^{3}\right)$ of the muckpile were used to backfill the emplacement shaft. The emplacement shaft was backfilled because small collapse features were observed in the soil adjacent to the existing concrete cover which could pose a threat to the public, livestock, or wildlife at the site. Approximately $5,000 \mathrm{~m}^{3}\left(6,535 \mathrm{yd}^{3}\right)$ of broken granite remains at the surface in an area of approximately $930 \mathrm{~m}^{2}\left(10,000 \mathrm{ft}^{2}\right)$. See Figure $2 \mathrm{for}$ locations of the emplacement shaft and muckpile.

No remedial activities were taken at the muckpile in 1997 . The following details the justification for no action:

- Process knowledge (DOE, 1997b) indicated that the muck pile was created prior to the testing of any nuclear devices at Project Shoal. 
- The post-detonation investigation (drill back) operation was conducted at a distance of approximately $320 \mathrm{~m}(1,050 \mathrm{ft})$ east of the site and did not affect the broken rock material that comprises the muckpile (AEC, 1970).

- The emplacement shaft and drifts (tunnels) at Project Shoal were constructed by mining into the granitic rocks that comprise the bulk of the Sand Springs Range where the Project Shoal site is located. Based on geologic descriptions of cuttings generated during the drilling efforts near the emplacement shaft in identical rock types, it was determined that the mineral composition of these rocks did not contain metals in greater than background concentrations (DOE, 1997b).

- Samples (DP-15, DP-16, and DP-17) were collected from weathered granite equivalents of the muckpile (approximately $274 \mathrm{~m}$ [900 ft] northeast of the muckpile and $150 \mathrm{~m}$ [500 $\mathrm{ft}$ ] north of the mud pit) during the September 1996 mud pit characterization activities (see Figure 2 for sample locations). The weathered granite samples were collected to provide analytical data regarding native background concentrations. Sample analytical results are summarized in Table 1 and are provided in Appendix A. The analytical results indicated no COC's were detected in excess of regulatory limits.

- Recontouring/regrading of the existing muckpile would be of minimal benefit as the resulting surface area would be significantly larger, and the existing native vegetation would be significantly impacted.

Considering the process knowledge presented above, DOE/NV recommends that the muckpile be closed in-place with no further action.

\subsubsection{Housekeeping Site}

The housekeeping site consisted of approximately 20 used, empty, rusted, steel 0.9 liter ( 1 quart) oil cans. The oil cans were probably generated during site activities in the 1960's based upon the construction material and style of can.

Closure activities consisted of removal and disposal of the empty oil cans and preparation of housekeeping documentation (Housekeeping Closure Verification Form in Appendix B). Copies of the photographs of the site before and after the remedial activities were completed and can be found in the Housekeeping Closure Verification Form (Appendix B). The oil cans were removed from the site on August 19, 1997. No discoloration of the soil adjacent to or below the cans was observed during removal activities. The cans were transported to the NTS for disposal on August 27, 1997. The cans were disposed of in the Area 23 Landfill located at the NTS. 


\section{TABLE 1 - SAMPLE ANALYTICAL RESULTS, GRANITE SAMPLES NEAR MUCKPILE}

\begin{tabular}{|c|c|c|c|c|c|c|c|c|c|c|}
\hline 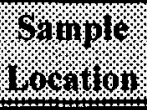 & $8 \%$ & 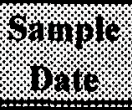 & Whyor. & sring & / & 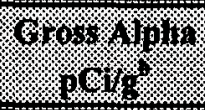 & 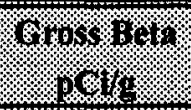 & 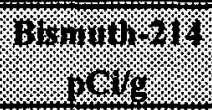 & 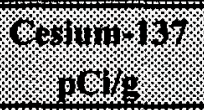 & 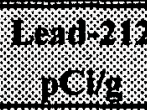 \\
\hline DP-15 & PSS00022 & $9 / 16 / 96$ & Soil & 104 & 7.4 & 23.9 & 27.1 & 1.03 & 0.24 (ND) & 1.01 \\
\hline DP-15 & PSS00023 & $9 / 16 / 96$ & Soil & 84.2 & 6.4 & 25.4 & 27.3 & 1.36 & 0.23 (ND) & 0.85 \\
\hline DP-16 & PSS00026 & $9 / 16 / 96$ & Soil & 141 & 10.2 & 35.9 & 30.0 & 0.82 & 0.23 (ND) & 1.04 \\
\hline DP-17 & PSS00027 & 9/16/96 & Soil & 103 & 10.2 & 27.3 & 25.8 & $N^{c}$ & $0.39(\mathrm{ND})$ & ND \\
\hline
\end{tabular}

\begin{tabular}{|c|c|c|c|c|c|c|c|c|c|c|}
\hline 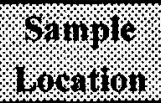 & Surrols: & S. & Wring: & 47. & 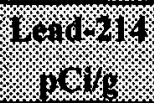 & I.14. & rindining: & Ying & Yion & 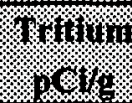 \\
\hline DP-15 & PSS00022 & $9 / 16 / 96$ & Soil & 23.2 & 0.95 & 2.84 & 1.23 & 0.36 & ND & ND \\
\hline DP-15 & PSS00023 & $9 / 16 / 96$ & Soil & 25.4 & 0.93 & ND & ND & 0.42 & ND & ND \\
\hline DP-16 & PSS00026 & $9 / 16 / 96$ & Soil & 21.2 & 0.83 & 3.43 & ND & 0.31 & 1.87 & ND \\
\hline DP- 17 & PSS00027 & $9 / 16 / 96$ & Soil & 17 & ND & ND & ND & 0.74 & ND & ND \\
\hline
\end{tabular}

Notes:

${ }^{\mathrm{a}} \mathrm{mg} / \mathrm{kg}=$ milligrams per kilogram

${ }^{\mathrm{b}} \mathrm{pCi} / \mathrm{g}=$ pico Curies per gram

${ }^{\mathrm{c}} \mathrm{ND}=$ Not detected above laboratory/method limit 


\subsection{DEVIATIONS FROM SAFER PLAN AS APPROVED}

No deviations from the approved SAFER Plan (DOE, 1997a) were implemented in the field for the mud pit closure activities.

A Record of Technical Change (DOE, 1997b) was submitted to the NDEP on September 3, 1997, to provide process knowledge in the CR for the closure in place of the muckpile (CAS 57-06-01) by no further action. Additionally, DOE/NV proposed in DOE, $1997 \mathrm{c}$ to remediate the housekeeping site (CAS 57-98-01) using the Housekeeping Site Work Plan (DOE, 1996) and provide the documentation in this CR. The Record of Technical Change (DOE, 1997b) and proposal to remediate the housekeeping site were recorded as approved on October 6, 1997 (NDEP, 1997b).

\subsection{CORRECTIVE ACTION SCHEDULE AS COMPLETED}

The project activities were completed as indicated in Figure 4.

The oil cans were removed from the housekeeping site on August 19, 1997. Transportation and disposal of the housekeeping site waste was completed on August 27, 1997.

The mud pit excavation and stockpiling activities were conducted from August 18, 1997 to August 25, 1997. The mud pit waste disposal activities were conducted on August 25 and 26, 1997. The verification samples were collected on August 19 and 25, 1997. Analytical results indicating the impacted materials exceeding the $100 \mathrm{mg} / \mathrm{kg}$ TPH action level were removed were received on August 27, 1997. Regrading and demobilization activities were completed on August 27, 1997.

\subsection{SITE PLAN/SURVEY PLAT}

A site plan reflecting the areas of closure activity addressed in this report is provided as Figure 2. As-Built surveys of the mud pit and muckpile areas were not proposed in the SAFER Plan (DOE, 1997a) or Record of Technical Change (DOE, 1997b) and were not implemented during or after field activities. 


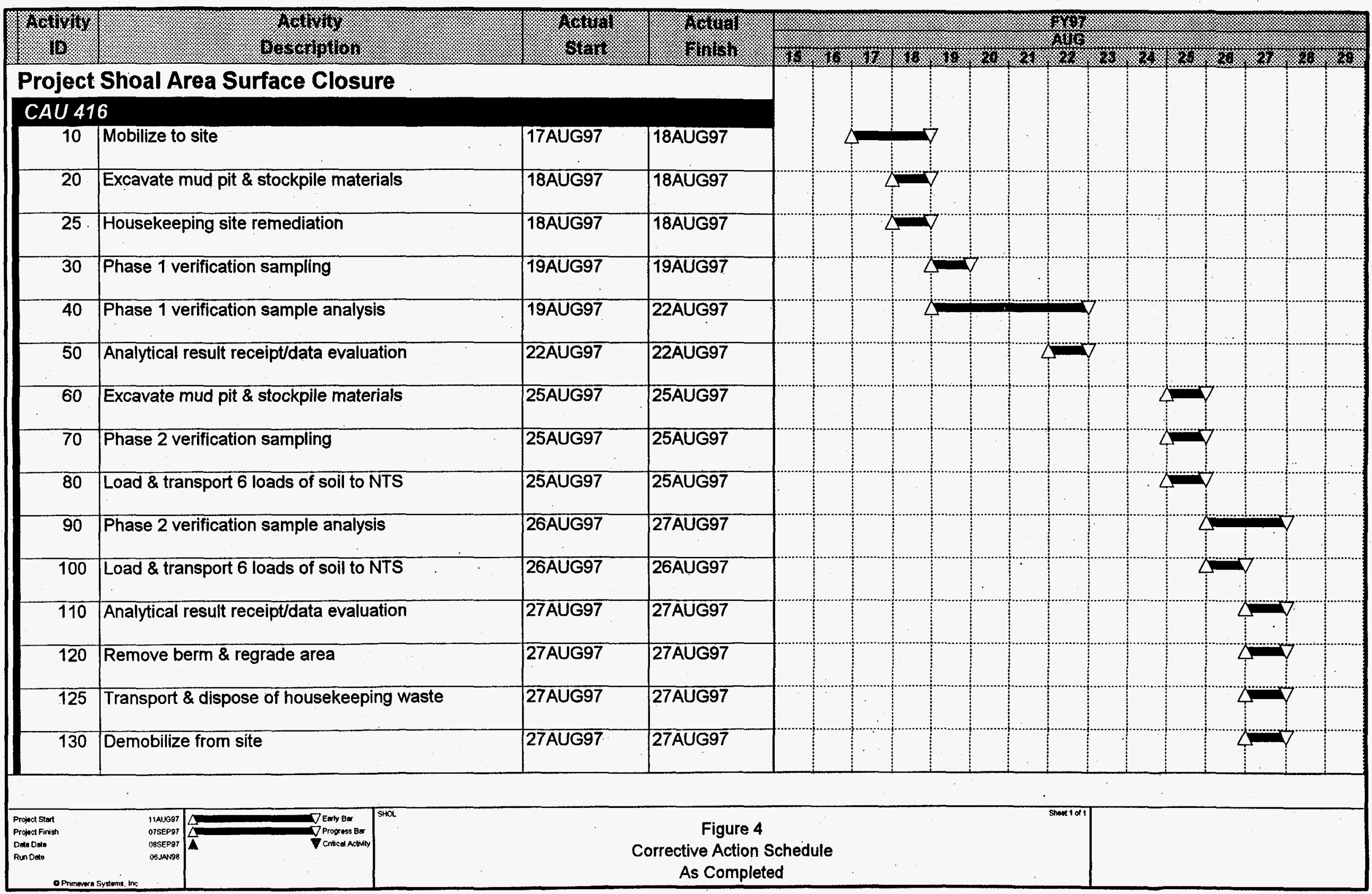




\subsection{WASTE DISPOSITION}

\subsection{WASTE MANAGEMENT ACTIVITIES}

The excavated soil from the mud pit was stockpiled on and covered with plastic approximately $30 \mathrm{~m}(100 \mathrm{ft})$ south of the mud pit and adjacent to the site access road. The soil was stockpiled on two layers of $10 \mathrm{mil}(0.01 \mathrm{in})$ plastic, covered with $10 \mathrm{mil}(0.01 \mathrm{in})$ plastic, and weighted on the edges for stabilization and management purposes. Excavation and stockpiling activities were conducted from August 18, 1997 to August 25, 1997.

Approximately $7.6 \mathrm{~L}$ ( $2 \mathrm{gal}$ ) of rinsate were generated from cleaning the excavation equipment buckets on August 26, 1997. The excavation equipment was cleaned with brooms and a light spray of Alconox ${ }^{\mathrm{TM}}$ and tap water from a hand sprayer. The cleaning activities were conducted over the final end-dump truck loaded with the last hydrocarbon impacted soil excavated from the mud pit area. The final end-dump truck contained approximately $15.3 \mathrm{~m}^{3}\left(20 \mathrm{yd}^{3}\right)$ of impacted soil and the plastic used to underlay and cover the excavated soil stockpile.

To eliminate the cleaning of the end-dump trucks (and the generation of additional equipment rinsate), $10 \mathrm{mil}$ (0.01 in) plastic was placed in each end dump truck prior to loading with soil. The trucks were also covered with a tarpaulin to comply with U.S. Department of Transportation regulations and requirements prior to transportation of the soil from the site to the Area 6 Hydrocarbon Landfill located at the NTS.

The used oil cans from the housekeeping site were removed from the site, placed in a plastic bag, and stored in a site vehicle on August 19, 1997. The housekeeping waste was transported to the NTS on August 27, 1997.

\subsection{WASTE DISPOSAL}

Mud pit waste disposal activities were conducted on August 25 and 26, 1997. Twelve approximately $15.3 \mathrm{~m}^{3}\left(20 \mathrm{yd}^{3}\right)$ loads of hydrocarbon impacted materials (drill cuttings, soil, weathered granite, and the plastic used to underlay and cover the soil stockpile) were disposed in the Area 6 Hydrocarbon Landfill located at the NTS. The total weight of material transported from the mud pit and disposed of in the Area 6 Hydrocarbon Landfill was approximately 294,800 kilograms (649,922 pounds). Copies of the Bills of Ladings, Weight Tickets, and Material Clearances (radiological green tags) required for disposal at the Area 6 Hydrocarbon Landfill can be found in Appendix C.

The used oil cans from the housekeeping site were disposed of in the NTS Area 23 Landfill on August 27, 1997. A copy of the Housekeeping Closure Verification Form and Material Clearance (radiological green tag) can be found in Appendix B. 


\subsection{CLOSURE VERIFICATION RESULTS}

Closure verification results are applicable for the mud pit and housekeeping site. The process knowledge (analytical results of granite samples collected near the muckpile and site geological data) for the closure of the muckpile is presented in Section 2.1.3. Two phases of excavation and verification sampling activities were required to remove the hydrocarbon impacted drilling mud and weathered granite from the mud pit area.

\subsection{MUD PIT}

\subsubsection{First Phase Of Verification Sampling/Analysis}

After removal of the hydrocarbon contaminated material from the mud pit, nine samples were collected from the bottom of the excavation area at eight sample points. Two samples were collected at the same location (Sample PSA-V04 is a field duplicate of Sample PSA-V03). The eight sample points were collected at the approximate locations of the 1996 direct-push characterization samples that exceeded the $100 \mathrm{mg} / \mathrm{kg}$ Action Level (DOE, 1997a). See Figure 3 for the locations of the 1996 characterization sample points and the verification sample points.

The verification samples were collected on August 19, 1997, from the exposed surface in the excavated area in accordance with the SAFER Plan (DOE, 1997a). Samples were collected using clean stainless-steel trowels. The samples were placed in 250 milliliter ( 8 ounce) glass jars, sealed, labeled, and stored in an ice-filled cooler pending delivery to the analytical laboratory. The samples were hand-carried to NEL Laboratories in Reno, Nevada, to be analyzed for TPH by method SW 846-8015 Modified. A 24-hour turn-around on the analyses was requested; however, problems with the laboratory equipment resulted in a 48-hour turnaround. The results were received and evaluated on August 22, 1997.

Analytical results are summarized in Table 2 and are provided in Appendix D. TPH concentrations for the nine verification samples ranged from below. $15 \mathrm{mg} / \mathrm{kg}$ to $170 \mathrm{mg} / \mathrm{kg}$. Five samples (PSA-V03, PSA-V04 [field duplicate of PSA-VO3], PSA-V05, PSA-V06, and PSA-V09) exceeded the action level of $100 \mathrm{mg} / \mathrm{kg}$. Results for these samples ranged from 110 $\mathrm{mg} / \mathrm{kg}$ to $170 \mathrm{mg} / \mathrm{kg} \mathrm{TPH}$. The location of the samples exceeding the $100 \mathrm{mg} / \mathrm{kg}$ action level was confined to the approximate northern half of the excavation area (Figure 3 ).

\subsubsection{Second Phase Of Verification Sampling/Analysis}

The second phase of excavation activities was initiated in the approximate northern half of the excavation area on August 25, 1997, after receipt and evaluation of the results indicating the 100 $\mathrm{mg} / \mathrm{kg}$ TPH action level was exceeded. Approximately $0.3 \mathrm{~m}(1 \mathrm{ft})$ of additional material 
TABLE 2 - SAMPLE ANALYTICAL RESULTS, FIRST PHASE OF VERIFICATION SAMPLES

\begin{tabular}{|c|c|c|c|c|}
\hline \multirow{2}{*}{$\begin{array}{l}\text { SAMPLE } \\
\text { NUMBER }\end{array}$} & \multirow{2}{*}{$\begin{array}{l}\text { DIRECT PUSH } \\
\text { IOCATION }\end{array}$} & \multicolumn{2}{|c|}{ TPH RESULTS (mg/kg) } & \multirow{2}{*}{$\begin{array}{l}\text { CRDI? } \\
\text { (mg/kg) }\end{array}$} \\
\hline & & DIESEL & $01 \mathrm{U}^{2}$ & \\
\hline PSA-V01 & DP-1 & 21 & 53 & 15 \\
\hline PSA-V02 & DP-4 & $\mathrm{ND}^{4}$ & ND & 15 \\
\hline PSA-V03 & DP-7 & 62 & 120 & 15 \\
\hline $\begin{array}{l}\text { PSA-V04 } \\
\text { (duplicate of } \\
\text { PSA-V03) }\end{array}$ & DP-7 & 38 & 130 & 15 \\
\hline PSA-V05 & DP-2 & 44 & 170 & 15 \\
\hline PSA-V06 & DP-5 & 51 & 130 & 15 \\
\hline PSA-V07 & DP-8 & 33 & 92 & 15 \\
\hline PSA-V08 & DP-18 & ND & ND & 15 \\
\hline PSA-V095 & $\mathrm{DP}-6$ & 48 & 110 & 15 \\
\hline
\end{tabular}

Notes:

${ }^{1}$ Diesel and fuel oil are $\mathrm{C}_{10-24}$ range hydrocarbons

${ }^{2}$ Waste and lubricating are $>\mathrm{C}_{24}$ range hydrocarbons

${ }^{3}$ Contract-Required Detection Limit

${ }^{4} \mathrm{ND}=$ Not detected above the laboratory/method limits

${ }^{5}$ Sample PSA-V09 collected approximately 3 meters (10 feet) southeast of DP-6 
was removed from the northern portion of the excavation area encompassed by sample points PSA-V03, PSA-V04 (field duplicate of PSA-VO3), PSA-V05, PSA-V06, and PSA-V09.

Following removal of the additional material, the sample locations which exceeded the 100 $\mathrm{mg} / \mathrm{kg}$ TPH action level were resampled. The sample locations can be found in Figure 3. Five additional verification samples (PSA-V10, PSA-V11 [field duplicate of PSA-V10], PSA-V12, PSA-V13, and PSA-V14) were collected in the same manner as described in Section 4.1. The samples were hand-carried to NEL Laboratories in Reno, Nevada, for analysis on August 25, 1997. The analytical results were received on August 27, 1997.

The analytical results are summarized in Table 3 and are provided in Appendix B. TPH concentrations for the five samples were below $15 \mathrm{mg} / \mathrm{kg}$.

The results of the analyses confirmed that the excavation of the additional material was successful in removing materials in the mud pit that exceeded the $100 \mathrm{mg} / \mathrm{kg} \mathrm{TPH}$ action level, and that no further excavation was necessary.

\subsection{HOUSEKEEPING SITE}

Verification results of the remediation activities consisted of taking photographs of the site before and after removal of the oil cans and preparation of the Housekeeping Closure Verification Form. Copies of the photographs are provided in the Housekeeping Closure Verification Form located in Appendix B. 
TABLE 3 - SAMPLE ANALYTICAL RESULTS, SECOND PHASE OF VERIFICATION SAMPLES

\begin{tabular}{|c|c|c|c|c|}
\hline \multirow{2}{*}{$\begin{array}{l}\text { SAMPLE } \\
\text { NUMBER }\end{array}$} & \multirow{2}{*}{$\begin{array}{l}\text { DIRECT PUSH } \\
\text { LOCATION }\end{array}$} & \multicolumn{2}{|c|}{ TPH RESULTS (mg/kg) } & \multirow{2}{*}{$\begin{array}{l}\mathrm{CRDI}^{3} \\
\text { (mg/kg) }\end{array}$} \\
\hline & & DIESEL & $\mathrm{OH}^{2}$ & \\
\hline PSA-V10 & $\mathrm{DP}-2$ & $\mathrm{ND}^{4}$ & ND & 15 \\
\hline $\begin{array}{l}\text { PSA-V11 } \\
\text { (duplicate of } \\
\text { PSA-V10) }\end{array}$ & DP-2 & ND & ND & 15 \\
\hline PSA-V12 & DP-5. & ND & ND & 15 \\
\hline PSA-V13 & DP-7 & ND & ND & 15 \\
\hline PSA-V14 & $\mathrm{DP}-6$ & $\mathrm{ND}$ & $\mathrm{ND}$ & 15 \\
\hline
\end{tabular}

Notes:

${ }^{1}$ Diesel and fuel oil are $\mathrm{C}_{10-24}$ range hydrocarbons

${ }^{2}$ Waste and lubricating are $>\mathrm{C}_{24}$ range hydrocarbons

${ }^{3}$ Contract-Required Detection Limit

${ }^{4} \mathrm{ND}=$ Not Detected above the laboratory/method limits

${ }^{5}$ Sample PSA-V14 collected approximately 3 meters (10 feet) southeast of DP-6 


\subsection{CONCLUSIONS AND RECOMMENDATIONS}

\subsection{CONCLUSIONS}

The closure of the PSA mud pit (CAS 57-09-01) was completed in accordance with the approved Streamlined Approach For Environmental Restoration Plan For Corrective Action Unit 416, Mud Pit. Project Shoal Area (DOE, 1997a) by excavation and disposal of the hydrocarbon impacted materials exceeding the $100 \mathrm{mg} / \mathrm{kg}$ TPH action level. The mud pit excavation area was backfilled, and the area was regraded using the clean soils from the retention berm.

The process knowledge was provided to substantiate the petition for closure in-place of the PSA muckpile (CAS 57-06-01) as proposed in the Record of Technical Change No. 1 For Streamlined Approach For Environmental Restoration Plan For Corrective Action Unit 416. Mud Pit. Project Shoal Area (DOE, 1997b). The process knowledge regarding the composition of the muckpile indicates that no COC's exceed regulatory action levels.

The housekeeping site was remediated in accordance with the approved the Houskeeping Site Work Plan (DOE, 1996) by removal and disposal of the debris and preparation of the Housekeeping Closure Verification Form.

\subsection{RECOMMENDATIONS}

The DOE/NV provides the following recommendations since the closure activities were completed as proposed:

- A Notice of Completion be provided by the NDEP to DOE/NV for the closure of the three CASs in CAU 416 (PSA mud pit [CAS 57-09-01], muckpile [CAS 57-06-01], and housekeeping site [CAS 57-98-01]).

- CAU 416 be moved from Appendix III to Appendix IV of the FFACO. 


\subsection{REFERENCES}

\section{U.S. Atomic Energy Commission, see AEC}

AEC, Nevada Operations Office, 1970. Site Disposal Report. Fallon Nuclear Test Site (Shoal). Churchill County, Nevada, NVO-73.

U.S. Department of Energy, see DOE

DOE, 1996. Housekeeping Category Corrective Action Unit Work Plan, Rev. 0, August 1996, DOE/NV-452, UC-700.

DOE, 1997a. Streamlined Approach For Environmental Restoration Plan For Corrective Action Unit 416. Mud Pit. Project Shoal Area, Rev. 1, July 1997, DOE/NV-479, UC-700.

DOE; 1997b. Record of Technical Change No. 1 For Streamlined Approach For Environmental Restoration Plan For Corrective Action Unit 416. Mud Pit, Project Shoal Area, Rev. 1. July 1997. DOE/NV-479. UC-700, August 8, 1997.

DOE, 1997c. DOE Proposed Modifications to FFACO Appendices, Fourth Quarter FY 1997 , Attachment IV of the Agenda Packet distributed at the FFACO meeting on August 13, 1997.

Desert Research Institute, see DRI

DRI, 1988. CERCLA Preliminary Assessment of DOE's Nevada Operations Office Nuclear Weapons Testing Areas. Las Vegas, NV.

Nevada Administrative Code, see NAC

NAC, 1996. State of Nevada Administrative Code 459.9921 through 459.999 Storage Tanks and 445A.347 Notification of Release of Pollutant.

Nevada Division of Environmental Protection, see NDEP

NDEP, 1996. The State of Nevada Department of Conservation and Natural Resources. Division of Environmental Protection and the U.S. Department of Energy and the U.S. Department of Defense Federal Facility Compliance Order And Agreement.

NDEP, 1997a. Letter from Paul J. Liebendorfer to Stephen A. Mellington, RE: SAFER For CAS 57-09-01. Shoal Surface Mud Pit. August 5, 1997.

NDEP, 1997b. Letter from Paul J. Liebendorfer to Stephen A. Mellington, $\underline{\text { RE: CAU/CAS }}$ Movements Proposed at the FFACO Quarterly Meeting of 08/13/97, September 19, 1997. 


\section{APPENDIX A}

\section{LABORATORY ANALYTICAL RESULTS GRANITE SAMPLES NEAR MUCKPILE}


Quanterra Incorporated 13715 Rider Trail North

Earth City, Missouri 63045

314 298-8566 Tolephone 314 298-8757 Fax

\section{CERTIFICATE OF ANALYSIS}

IT Las Vegas

October 13, 1996

4330 South Valley View

Suite 114

Las Vegas, NV 89103-4047

Attention: Mr. Kurt Schmidt

Ir Las Vegas Project Number

Quanterra, St. Louis Project Number

SDG Number

Date Received

Number of Samples

Sample type
: Project Shoal

: 317.55

: 12173

: September 17, 1996

: Twenty-six (26)

: Water and Soil

DVRODUCION

The following samples from the Nevada Test Site were received at Quanterra, St. Louis for TCLP Volatiles, TCLP Semi-Volatiles, TCLP Metais, Total Barium, Chromium, Gamma, Rad-Screen, Tritium, Total Petroleum Hydrocarbon (Diesel and Gasoline), and Gross Alpha/Beta.

Reviewed and Approved

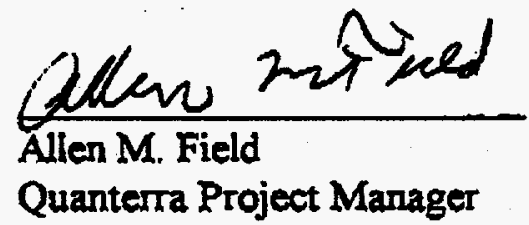


PAGE 2 of 4

October 13, 1996

IT Las Vegas Project Number $\quad$ : Project Shoal

Quanterra, St. Louis Project Number : 317.55

The samples were labeled as follows:

\begin{tabular}{|c|c|c|}
\hline CLIENT ID & LABID & Matrix \\
\hline PSS00001 & $12173-001$ & Soil \\
\hline PSSO0002 & $12173-002$ & Soil \\
\hline PSS00008 & 12173-003 & Soil \\
\hline PS\$00009 & $12173-004$ & Soil \\
\hline PSS00014 & $12173-005$ & Soil \\
\hline PSS00024 & $12173-006$ & Soil \\
\hline PSS00016 & 12173-007 & Soil \\
\hline PSS00011 & $12173-008$ & Soil \\
\hline PSS00007 & $12173-009$ & Soil \\
\hline PSS00013 & $12173-010$ & Soil \\
\hline PSS00028 & $12173-011$ & Soil \\
\hline PSS00029 & $12173-012$ & Soil \\
\hline PSS00022 & 12173-013,DUP,MS & Soil \\
\hline PSS00023 & $12173-014$ & Soil \\
\hline PSS00026 & $12173-015$ & Soil \\
\hline PSS00027 & $12173-016$ & Soil \\
\hline PSS00019 & $12173-017$ & Soil \\
\hline PSS00020 & $12173-018$ & Soil \\
\hline PSS00021 & $12173-019$ & Soil] \\
\hline PSSO0010 & 12173-020,DUP,MS,MSD & Soil \\
\hline PSS00005 & $12173-021$ & Soil \\
\hline PSS00006 & $12173-022$ & Soil \\
\hline PST00003 & $12173-023$ & Water \\
\hline PSS00030 & $12173-024$ & Water \\
\hline PSS00031 & $12173-025$ & Water \\
\hline PST00004 & $12173-026$ & Water \\
\hline
\end{tabular}

\section{ANALYTICAL RESULTS/METHODOLOGY}

The analytical results are presented in the enclosed Certificate of Analysis and EDD Disk. This report includes information on client identification numbers, lab identification numbers, preparation date, analysis date, results, units, and results for quality control samples.

The following table is a list of the analyses requested and the methods used for the above samples: 
PAGE 3 of 4

October 13, 1996

IT Las Vegas Project Number

: Project Shoal

Quanterra, St. Louis Project Number

: 317.55

$\begin{array}{ll}\text { Analysis } & \text { Method } \\ \text { Barium, Chromium } & \text { EPA 6010 } \\ \text { TCLP Metals } & \text { EPA 1311/7470/6010 } \\ \text { Gamma Scan } & \text { EPA } 901.1 \\ \text { Tritium } & \text { EERF H.01 } \\ \text { TPH (Diesel and Oil) } & \text { EPA 8015 } \\ \text { Gross Alpha/Beta } & \text { EPA 900.0 } \\ \text { TCLP Volatiles } & \text { EPA 1311/8240 } \\ \text { TCLP Semivolatiles } & \text { EPA 1311/8270 }\end{array}$

\section{OUALITY CONTROL}

Method blanks and laboratory control samples were analyzed with the sampies listed above for each parameter. Duplicates, matrix spike and matrix spike duplicate were performed as indicated above and as requested by the client.

\section{NONCONFORMANCE}

Metals

The was a nonconformance associated with SDG 12173. The digestion batch for waters of which sample PSSO0030 (12173-024) was associated was digested containing 21 analytical samples, one more than the twenty sample limit. Do to a $Q C$ requirement of another sample within the batch two laboratory control samples were also analyzed. within the batch.

\section{COMMENTS}

Login 12173 was received at a temperature of $2 / 2 / 2^{\circ} \mathrm{C}$.

\section{Analvtical Notes}

$\underline{\text { Metals }}$

The relative percent difference for chromium in sample PSS00022 (12173-013) was $25.1 \%$ and above the $20 \%$ limit. The associated data was flagged with an asterisk. 
PAGE 4 of 4

October 13, 1996

- IT Las Vegas Project Number : Project Shoal

Quanterra, St. Louis Project Number

: 317.55

\section{OUALINITRS/DEFINITIONS}

* : Values outside of QC limits.

B : Results were between the PQL and the IDL.

U : Results are less than the $\mathrm{DL}$.

$\mathrm{J} \quad$ : An estimated value.

ND : Parameter was analyzed for but not detected.

UG/L : : Micrograms per Liter.

MGIL : Milligrams per Liter.

pCil : Picocurries per liter.

NA : Not applicable.

\%REC : : Percent Recovery.

DUP : Duplicate.

QCBLK : Laboratory Method Blank.

QCLCS : : Laboratory Control Sample.

Qual. : Qualifier.

LCL : Lower Control Limits.

UCL : Upper Control Limits.

PQL : Practical Quantitation Limit.

MDA : Minimum Detectable Activity. 
IT-Las Vegas

4330 s Valley View

Suite 114

Las Veges, MY 89103

Project: 317.55
Category: ICAP Metals
Method: EPA 6010

Matrix: Soil
Sumple Date : 09/16/96

Receipt Date : 09/17/96

Report Date : 10/19/96

Quanterra 10 : 12173-013

Client 10: PSS00022

Prep. Analyses

Date Date
Detection Limit Dilution

Anatyte

cas Numer

Blank Sample

$10 / 04 / 96$

$10 / 04 / 96$

$10 / 04 / 96$

$7440-39-3$
$7440-47-3$

QCBLK115574-1

$10 / 04 / 96$

Result Unit Oual.

20.0

20.0

1


IT-Las Vegas

4330 s valley view

Suite 114

Las Vegas, WV 89103

Project: 317.55

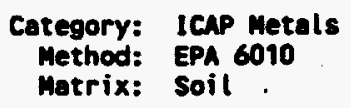

Client 1D: PSS000z20UP
Sample Date : 09/16/96

Receipt Date : 09/17/96

Report Date : 10/19/96

Quanterra ID : 12173-0130
Anelyte

Berium

Chromium
Prep. Anatyses

Dete

Date
$10 / 04 / 96$

$7440-39-3$

$7440-47-3$
OCBLK115574-1

ACBLK115574-1
$10 / 04 / 96$

$10 / 04 / 96$

Result Unit Qual.

Detection

Limit Dilution

$10 / 04 / 96 \quad 93.3 \mathrm{mg} / \mathrm{kg}$

$5.8 \mathrm{mg} / \mathrm{kg}$

20.0

20.0
1.0

1


IT-Las Vegas

$4330 \mathrm{~s}$ valley view

Suite 114

Las Vegas, MV 89103

Project: 317.55
Category: ICAP Metals

Matrix: Soil

Client 10: PSS0002214S
Sample Date : 09/16/96

Receipt Date : 09/17/96

Report Date : 10/19/96

Quanterra 10 : 12173-0134S

\begin{tabular}{|c|c|c|c|c|c|c|c|c|c|}
\hline Analyte & CAS Number & $\begin{array}{l}\text { Blank Sample } \\
\text { Mane }\end{array}$ & $\begin{array}{l}\text { Prep. } \\
\text { Date }\end{array}$ & $\begin{array}{l}\text { Analyses } \\
\text { Date }\end{array}$ & Result & Unit & Qual. & $\begin{array}{l}\text { Detection } \\
\text { Limit }\end{array}$ & Dilution \\
\hline $\begin{array}{l}\text { Barium } \\
\text { Chromium }\end{array}$ & $\begin{array}{l}7440-39-3 \\
7440-47-3\end{array}$ & $\begin{array}{l}\text { OCBLK115574-1 } \\
\text { OCBLK115574-1 }\end{array}$ & $\begin{array}{l}10 / 04 / 96 \\
10 / 04 / 96\end{array}$ & $\begin{array}{l}10 / 04 / 96 \\
10 / 04 / 96\end{array}$ & $\begin{array}{l}91 \\
90\end{array}$ & $\begin{array}{l}\text { XREC } \\
\text { XRREC }\end{array}$ & & & $\begin{array}{l}1 \\
1\end{array}$ \\
\hline
\end{tabular}


$1 T$-Las Vegas

4330 s Valley view

Suite 114

Las Vegas, WN 89103

Project: 317.55
Category: ICAP Metals

Method: EPA 6010

Matrix: Soil

Client 10: P5500023
Semple Date : 09/16/96

Receipt Date : $09 / 17 / 96$

Report Date : 10/19/96

Quanterra 10 : 12173-014
Analyte

Barium

Chromiun
Cas Number

$7440-39-3$

$7440-47-3$

\section{Blank Sample Name}

OCBLK115574-1

OCBLK115574-1
Prep. Analyses
Date

$10 / 04 / 96$ $10 / 04 / 96$
$10 / 04 / 96$

$10 / 04 / 96$

Result Unit

Result Unit Ougl.

$84.2 \mathrm{mg} / \mathrm{kg}$

$6.4 \mathrm{mg} / \mathrm{kg}$
Detection

Limit Dilution

20.0

1.0

1


IT-Les Vegas

4330 s Valley view

Suite 114

Las Vegas, WV 89103

Project: 317.55
Category: ICAP Metals

Method: EPA 6010

Matrix: Soil

Client ID: Pss00026

Semple Date : $09 / 16 / 96$

Receipt Date : $09 / 17 / 96$

Report Date : $10 / 19 / 96$

Quanterra ID: 12173-015

Anatyre

cas Nuber

Bariun

Chronium

$7 \longdiv { 4 6 0 - 3 9 - 3 }$
Blank Semple Nane
Prep. Analyses

Date Date
Result Unit Qual.

$10 / 04 / 96 \quad 10 / 04 / 96$

$141 \mathrm{hig} / \mathrm{kg}$

Detection

Limit Dilution

20.0

1.0 
IT-Las Vegas

4330 S Valley Viem

Suite 114

Las Vegas, wV 89103

Project: 317.55
Category: ICAP Metals

Method: EPA 6010

Matrix: Soil

Client 1D: PS500027
Sample Date : 09/16/96 Receipt Date : $09 / 17 / 96$ Report Date : 10/19/96

Quanterra ID : 12173-016

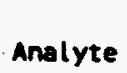

Barium

Chromium

Prep. Analyses
Date

Cas Number

Blank Sample

OCBLK115574-9

$7440-39-3$

OCBLK115574-1
Date

$10 / 04 / 96$

10/04/96

$10 / 04 / 96$
Result Unit Qual.

103
$10.2 \mathrm{mg} / \mathrm{kg}$
$\mathrm{mg} / \mathrm{kg}$

Detection

Limit Dilution

20.0

1



11 - Las Vegas

$4330 \mathrm{~s}$ Valley view

suite 114

Las Vegas, NV 89103

Project: 317.55

Category: CAMMA SCAN

Method:

EPA 901.1

\begin{tabular}{|c|c|c|c|c|c|c|c|c|c|c|c|}
\hline $\begin{array}{l}\text { Client } \\
\text { ID }\end{array}$ & $\begin{array}{l}\text { Laboratory } \\
\text { I0 }\end{array}$ & Matrix & $\begin{array}{l}\text { Date } \\
\text { Sampled }\end{array}$ & $\begin{array}{l}\text { Date } \\
\text { Received }\end{array}$ & $\begin{array}{l}\text { Prep } \\
\text { Date }\end{array}$ & $\begin{array}{l}\text { Oate } \\
\text { Analyzed }\end{array}$ & Parameter & Result & $\begin{array}{l}\text { Sigma } \\
\text { Error } \\
(+/-)\end{array}$ & MDA & Units \\
\hline \multirow[t]{3}{*}{ PSS00022 } & $12173 \cdot 013$ & Soil & $09 / 16 / 96$ & $09 / 17 / 96$ & $09 / 23 / 96$ & $09 / 26 / 96$ & That lium-208 & 0.36 & 0.17 & 0.24 & $\mathrm{pCi} / \mathrm{g}$ \\
\hline & & & & & & & Bismuth 214 & 1.03 & 0.34 & 0.35 & $\mathrm{pcl} / \mathrm{s}$ \\
\hline & & & & & & & Lead-214 & 0.95 & 0.26 & 0.27 & $\mathrm{pCl} / \mathrm{s}$ \\
\hline \multirow[t]{6}{*}{ PSS00022DUP } & 12173-013DUP & Soil & $09 / 16 / 96$ & $09 / 17 / 96$ & $09 / 23 / 96$ & $09 / 26 / 96$ & Cesium-137 & 0.19 & $\cdots$ & 0.19 & $\mathrm{pCl} / \mathrm{g}$ \\
\hline & & & & & & & Potass ium- 40 & 26.9 & 4.8 & 2.1 & $\mathrm{pCl} / \mathrm{s}$ \\
\hline & & & & & & & Radium-228 & 1.69 & 0.57 & 0.68 & $\mathrm{pCi} / \mathrm{g}$ \\
\hline & & & & & & & Lead-212 & 1.05 & 0.25 & 0.23 & $\mathrm{pCi} / \mathrm{g}$ \\
\hline & & & & & & & Thall lium-208 & 0.61 & 0.21 & 0.18 & pCi/g \\
\hline & & & & & & & Lead-214 & 1.05 & 0.30 & 0.32 & pci/g \\
\hline \multirow[t]{6}{*}{ PSS00023 } & $12173-014$ & Soil & $09 / 16 / 96$ & $09 / 17 / 96$ & $09 / 23 / 96$ & $10 / 07 / 96$ & Ces ium-137 & 0.23 & $\cdots$ & 0.23 & $\mathrm{pCi} / \mathrm{g}$ \\
\hline & & & & & & & Potassium-40 & 25.4 & 4.8 & 1.8 & $\mathrm{pCi} / \mathrm{g}$ \\
\hline & & & & & & & Lead-212 & 0.85 & 0.38 & 0.32 & $\mathrm{pCi} / \mathrm{g}$ \\
\hline & & & & & & & Thall ium-208 & 0.42 & 0.17 & 0.16 & $\mathrm{pCi} / \mathrm{g}$ \\
\hline & & & & & & & Bismuth 214 & 1.36 & 0.36 & 0.32 & $\mathrm{pCi} / \mathrm{g}$ \\
\hline & & & & & & & Lead-214 & 0.93 & 0.28 & 0.32 & $\mathrm{pCl} / \mathrm{g}$ \\
\hline \multirow[t]{8}{*}{ PSS00026 } & $12173-015$ & Soil & $09 / 16 / 96$ & $09 / 17 / 96$ & $09 / 23 / 96$ & $10 / 07 / 96$ & Cesium-137 & 0.23 & $\cdots$ & 0.23 & $\mathrm{pCl} / \mathrm{g}$ \\
\hline & & & & & & & Potassium- 40 & 21.2 & 4.1 & 2.1 & pci/g \\
\hline & & & & & & & Radium-226 & 3.43 & 2.73 & 2.72 & $\mathrm{pCi} / \mathrm{g}$ \\
\hline & & & & & & & Thor ium-234 & 1.87 & 1.06 & 1.40 & $p c i / g$ \\
\hline & & & & & & & Lead-212 & 1.04 & 0.22 & 0.21 & $\mathrm{pCi} / \mathrm{g}$ \\
\hline & & & & & & & That 1 ium-208 & 0.31 & 0.17 & 0.22 & $\mathrm{pCi} / \mathrm{g}$ \\
\hline & & & 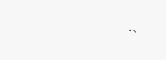 & & & & Bismuth 214 & 0.82 & 0.34 & 0.33 & $\mathrm{pCi} / \mathrm{g}$ \\
\hline & & & & & & & Lead-214 & 0.83 & 0.26 & 0.31 & $\mathrm{pCi} / \mathrm{g}$ \\
\hline
\end{tabular}




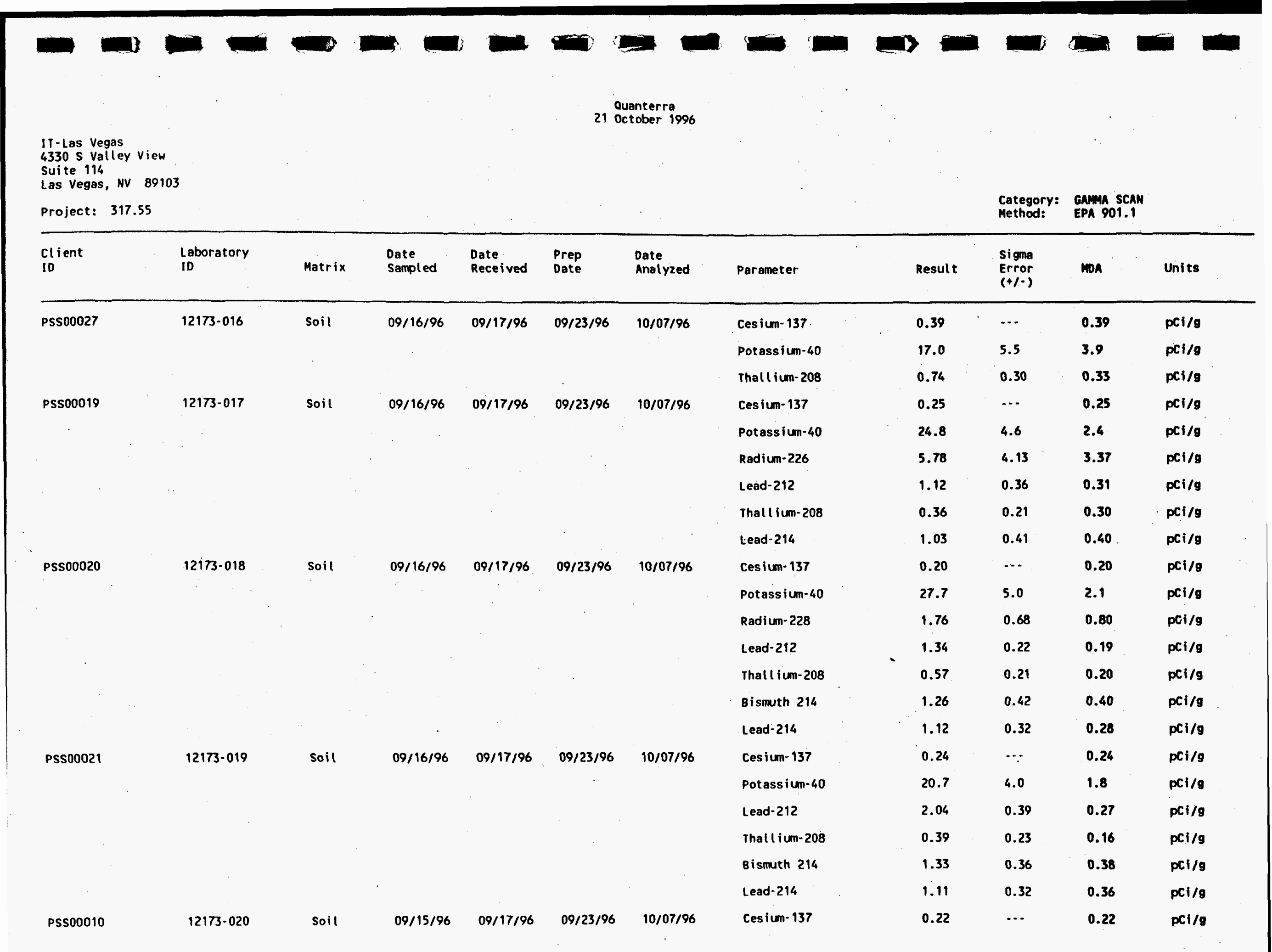


11-Las Vegas

$4330 \mathrm{~s}$ valley view

Suite 114

Las Vegas, NV 89103

Project: 317.55

Category: Gross Alpha/Beta Method: EPA 900.0

\begin{tabular}{|c|c|c|c|c|c|c|c|c|c|c|c|}
\hline $\begin{array}{l}\text { Client } \\
\text { ID }\end{array}$ & $\begin{array}{l}\text { Laboratory } \\
\text { ID }\end{array}$ & Matrix & $\begin{array}{l}\text { Date } \\
\text { Sampled }\end{array}$ & $\begin{array}{l}\text { Date } \\
\text { Received }\end{array}$ & $\begin{array}{l}\text { Prep } \\
\text { Date }\end{array}$ & $\begin{array}{l}\text { Date } \\
\text { Analyzed }\end{array}$ & Parameter & Result & $\begin{array}{l}\text { Si gma } \\
\text { Error } \\
(+/-)\end{array}$ & MOA & Units \\
\hline \multirow[t]{2}{*}{ PSS00022 } & $12173-013$ & Soil & $09 / 16 / 96$ & $09 / 17 / 96$ & $09 / 26 / 96$ & $10 / 02 / 96$ & Gross Alpha & 23.9 & 3.5 & 1.8 & $\mathrm{pCi} / \mathrm{g}$ \\
\hline & & & & & & & Gross Beta & 27.1 & 3.0 & 1.8 & $\mathrm{pCi} / \mathrm{g}$ \\
\hline \multirow[t]{2}{*}{ PSS000220UP } & $12173-0130 \mathrm{dP}$ & Soil & $09 / 16 / 96$ & $09 / 17 / 96$ & $09 / 26 / 96$ & $10 / 02 / 96$ & Gross Alpha & 25.3 & 3.6 & 1.7 & $\mathrm{pCi} / \mathrm{g}$ \\
\hline & & & & & . & & Gross Beta & 25.1 & 2.8 & 1.7 & $\mathrm{pci} / \mathrm{g}$ \\
\hline \multirow[t]{2}{*}{ PSS00023 } & $12173-014$ & Soil & $09 / 16 / 96$ & $09 / 17 / 96$ & $09 / 26 / 96$ & $10 / 02 / 96$ & Gross Alpha & 25.4 & 3.7 & 2.0 & $\mathrm{pci} / \mathrm{g}$ \\
\hline & & & & . & & & Gross Beta & 27.3 & 3.0 & 1.7 & $\mathrm{pCi} / \mathrm{g}$ \\
\hline \multirow[t]{2}{*}{ PSS00026 } & $12173-015$ & Soil & $09 / 16 / 96$ & $09 / 17 / 96$ & $09 / 26 / 96$ & $10 / 02 / 96$ & Gross Alpha & 35.9 & 4.7 & 1.8 & $\mathrm{pCi} / \mathrm{g}$ \\
\hline & & & & & & & Gross Beta & 30.0 & 3.3 & 1.6 & $\mathrm{pCi} / \mathrm{g}$ \\
\hline \multirow[t]{2}{*}{ PSS00027 } & $12173-016$ & Soil & $09 / 16 / 96$ & $09 / 17 / 96$ & $09 / 26 / 96$ & $10 / 02 / 96$ & Gross Alpha & 27.3 & 3.9 & 2.3 & $\mathrm{pCl} / \mathrm{g}$ \\
\hline & & & & & & & Gross Beta & 25.8 & 2.9 & 1.8 & $\mathrm{pci} / \mathrm{g}$ \\
\hline \multirow[t]{2}{*}{ PSS00019 } & $12173-017$ & Soil & $09 / 16 / 96$ & $09 / 17 / 96$ & $09 / 26 / 96$ & $10 / 02 / 96$ & Gross Alpha & 19.6 & 3.1 & 1.9 & $\mathrm{pci} / \mathrm{g}$ \\
\hline & & & & & & & Gross Beta & 24.2 & 2.8 & 1.8 & $\mathrm{pCi} / \mathrm{g}$ \\
\hline \multirow[t]{2}{*}{ PSS00020 } & $12173-018$ & Soil & $09 / 16 / 96$ & $09 / 17 / 96$ & $09 / 26 / 96$ & $10 / 02 / 96$ & Gross Alpha & 40.6 & 5.1 & 1.8 & $\mathrm{pCi} / \mathrm{g}$ \\
\hline & & & & & & & Gross Beta & 57.9 & 6.0 & 1.7 & $\mathrm{pci} / \mathrm{g}$ \\
\hline \multirow[t]{2}{*}{ PSS00021 } & $12173-019$ & Soil & $09 / 16 / 96$ & $09 / 17 / 96$ & $09 / 26 / 96$ & $10 / 02 / 96$ & Gross Alpha & 53.9 & 6.5 & 1.9 & $\mathrm{pCi} / \mathrm{s}$ \\
\hline & & & & & " & & Gross Beta & 37.7 & 4.0 & 1.8 & $\mathrm{pCi} / \mathrm{g}$ \\
\hline \multirow[t]{2}{*}{ PSSO0010 } & $12173-020$ & Soil & $09 / 15 / 96$ & $09 / 17 / 96$ & $09 / 23 / 96$ & $09 / 26 / 96$ & Gross Alpha & 27.7 & 3.9 & 1.9 & $\mathrm{pCi} / \mathrm{g}$ \\
\hline & & & & & & & Gross Beta & 18.5 & 2.2 & 1.7 & $\mathrm{pCl} / \mathrm{g}$ \\
\hline \multirow[t]{2}{*}{ PSS00010DUP } & 12173-020DUP & Soil. & $09 / 15 / 96$ & $09 / 17 / 96$ & $09 / 23 / 96$ & $09 / 26 / 96$ & Gross Alpha & 24.0 & 3.8 & 2.6 & $\mathrm{pCl} / \mathrm{g}$ \\
\hline & & & & & & & Gross Beta & 15.6 & 2.0 & 1.9 & $\mathrm{pCi} / \mathrm{g}$ \\
\hline \multirow[t]{2}{*}{ PSS00005 } & $12173-021$ & Soil & $09 / 15 / 96$ & $09 / 17 / 96$ & $09 / 26 / 96$ & $10 / 02 / 96$ & Gross Alpha & 10.6 & 2.9 & 3.5 & $\mathrm{pci} / \mathrm{g}$ \\
\hline & & & & & & & Gross Beta & 22.3 & 2.6 & 1.6 & pCi/g \\
\hline PSS00006 & $12173-022$ & Soil & $09 / 15 / 96$ & $09 / 17 / 96$ & $09 / 26 / 96$ & 10/02/96 & Gross Alpha & 21.0 & 3.4 & 2.4 & $\mathrm{pCi} / \mathrm{g}$ \\
\hline
\end{tabular}


ANALYSIS REQUEST AND CHAIN OF CUSTODY RECORD*

Project Name/No Shal/764044,0308010i Samples Shipment Date? $7 / 16 / 76$ Samplé Team Members'anucdra, Schmidt, Wether

Profit Center No. 3663710

Project Manager 4 Gretzky

Purchase Order No. 69627

Required Report Date $11 \quad 10 / 17 / 96$
Lab Destination $8 \quad$ Quanterra

Lab Contact 9 Allen Field

Reference Document No. 51.9801, Page 1 of 2

Bill to: 5 IT Corporation 4330 s valley view*114
La's vegas $N v$ z910.3 Project Contact/Phone 13 chmidt $/ 4-17+3$ Report to: 10 Syl Hersh Carrier/Waybill No. Bed Ex 8718056874 ONE CONTAINER PER LINE

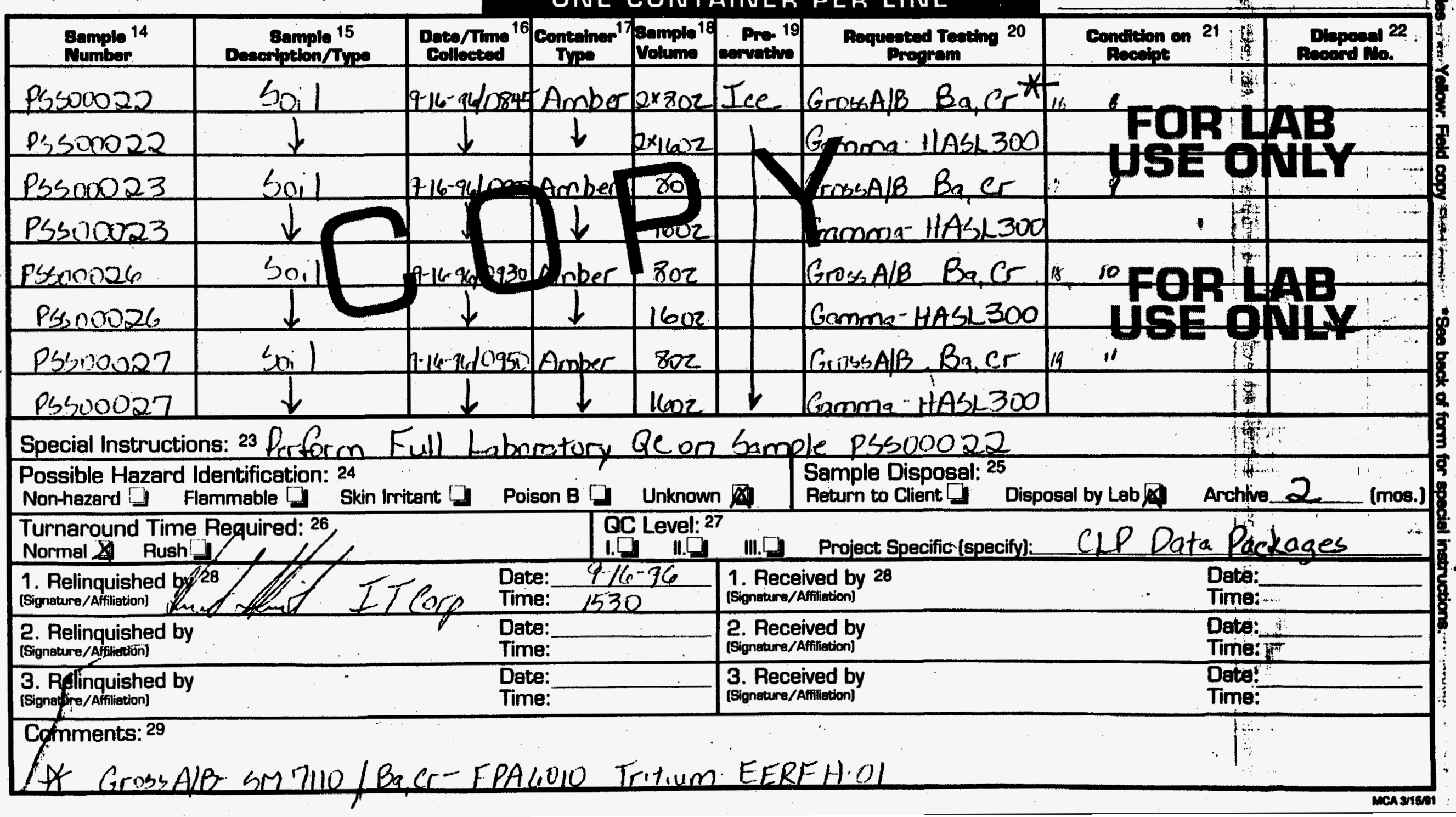


INTERNATIONAL TECHNOLOGY CORPORATION
SAMPLE COLLECTION LOG

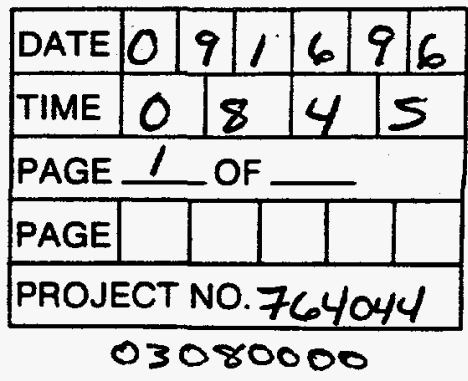

PROJECT NAME SHOAK MUOPT ChaCACTER/zation SAMPLE NO. PSS00022

SAMPLE LOCATION $D P-15$ SAMPLE TYPE SOM - SHARON COMPOSITE $\checkmark$ YES NO COMPOSITE TYPE SPATIAL OF DP -IS DEPTH OF SAMPLE $\quad 0-Z E T$ WEATHER PARTY SWAY, TEMP YO

(BAckiorovinn Location)

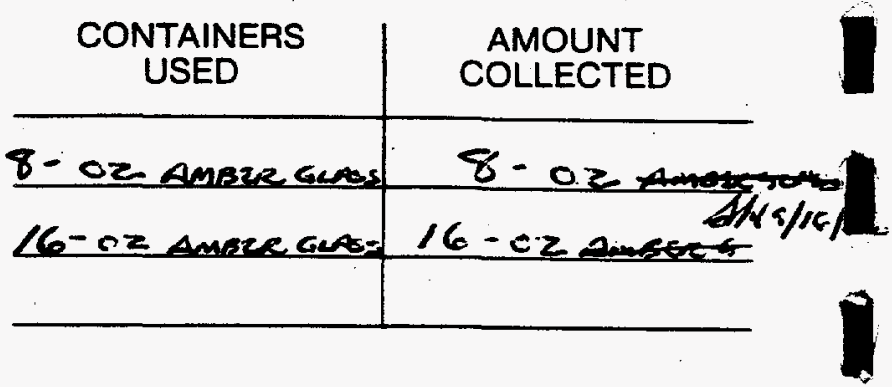

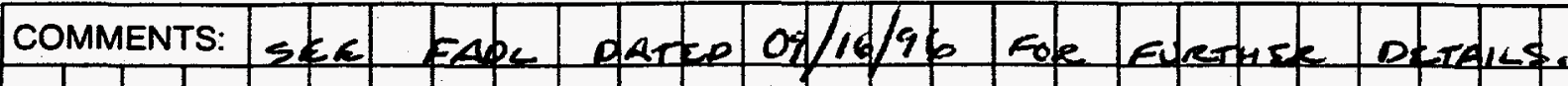

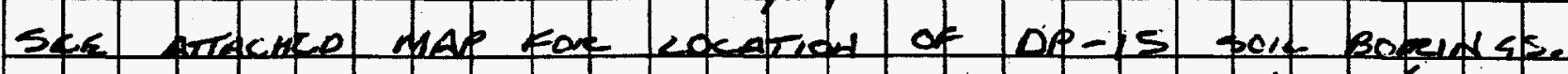

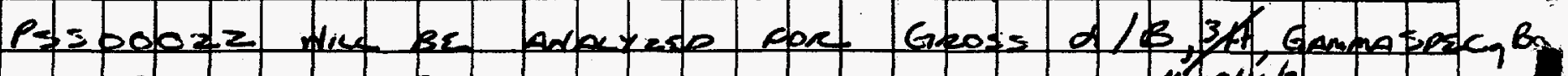

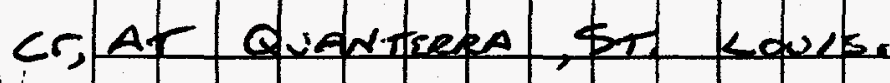

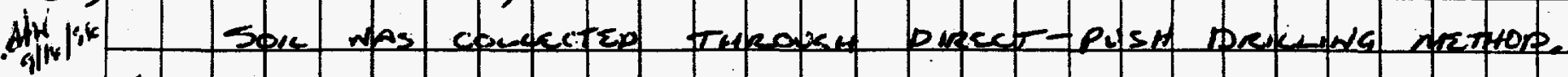

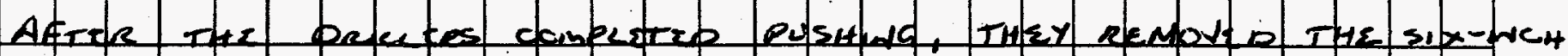

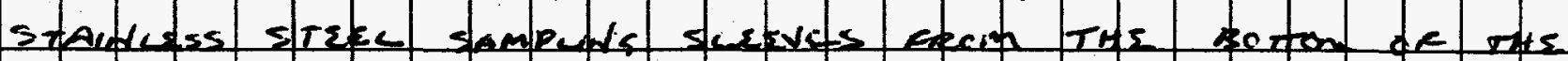

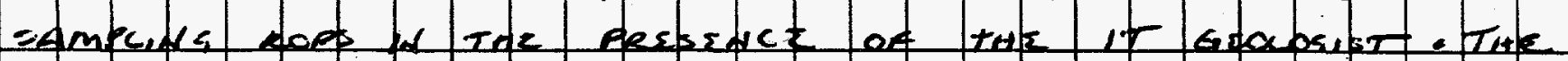

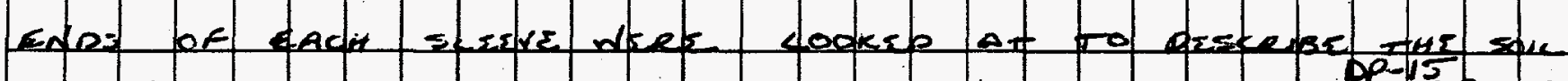

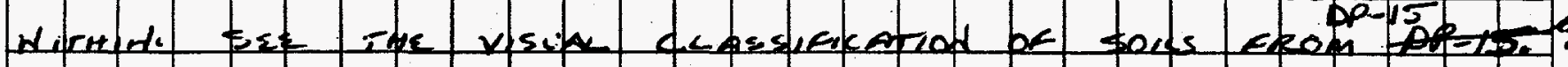

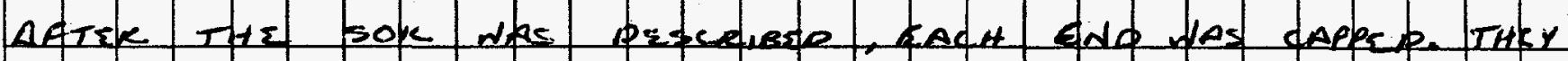

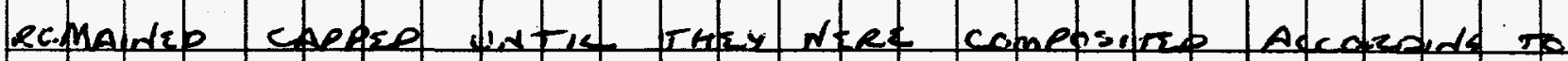

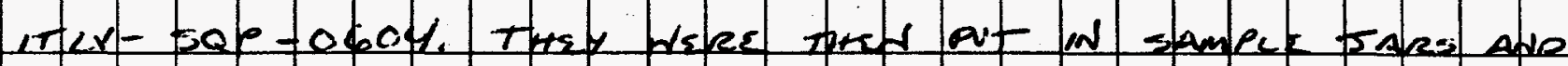

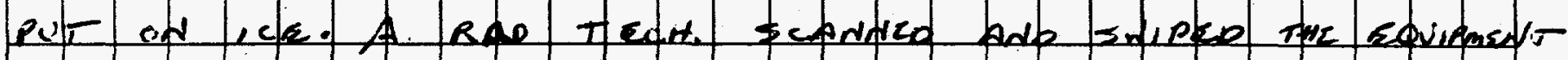

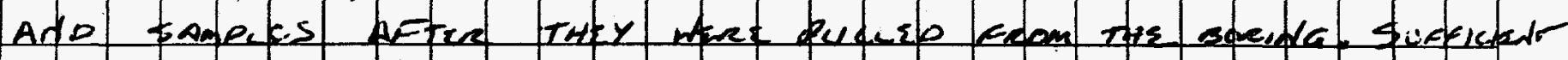

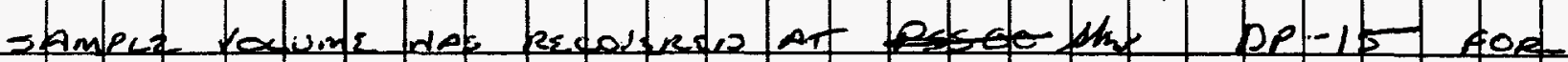

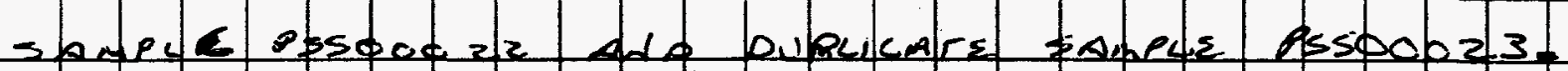

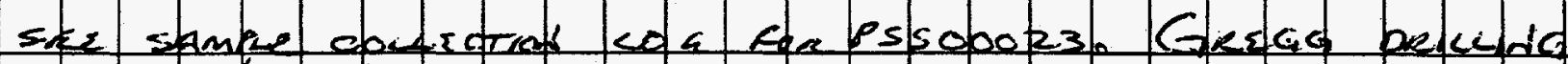

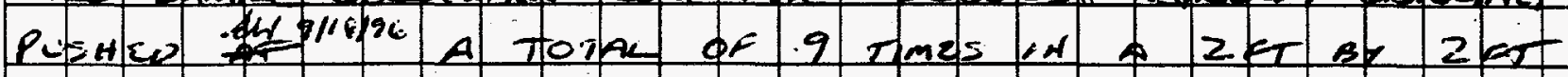

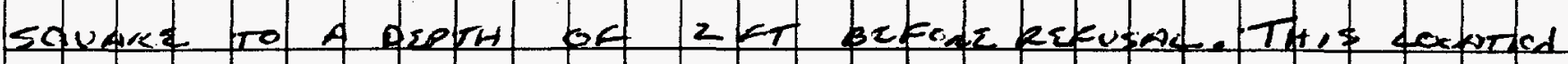

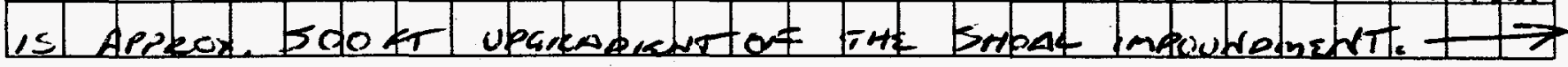

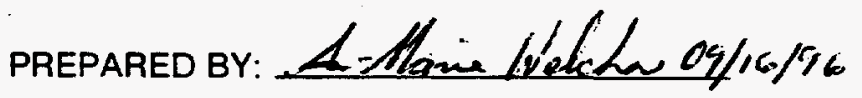


INTERNATIONAL TECHNOLOGY CORPORATION

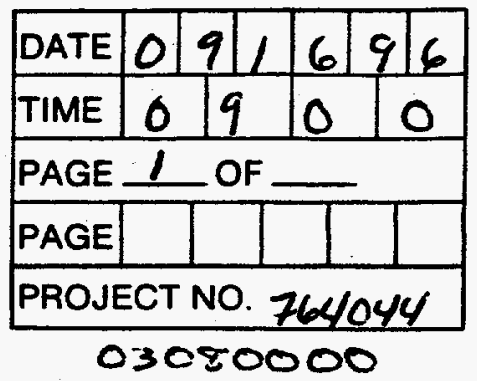

PROJECT NAME - ShCAK MupRIT CharacterLzatiod SAMPLENO. PSSOOOZ3

SAMPLELOCATION DP-iS (PVPLICATE eF Pss00022) (BACEGROUNO

SAMPLE TYPE SOK-SHAWCAV

COMPOSITE $V$ YES NO

COMPOSITE TYPE SPATIRC OF DP-15

DEPTH OF SAMPLE

WEATHER PAETLY SiNNY TEMP YO"P

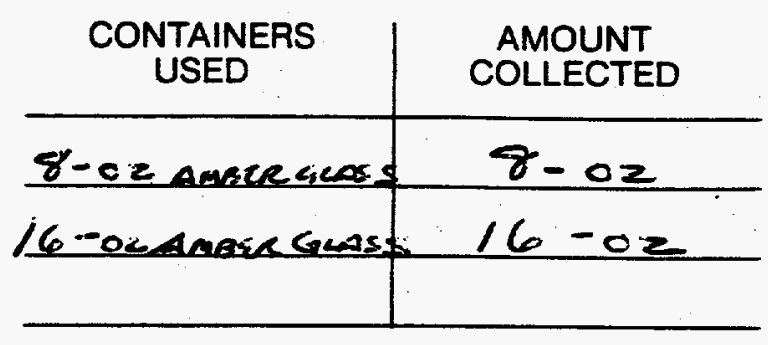

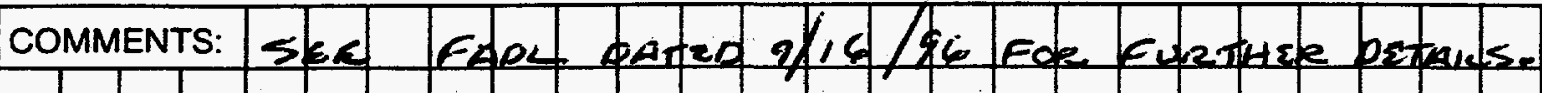

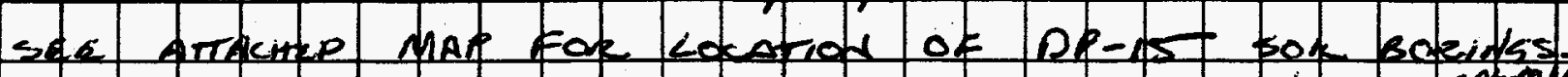

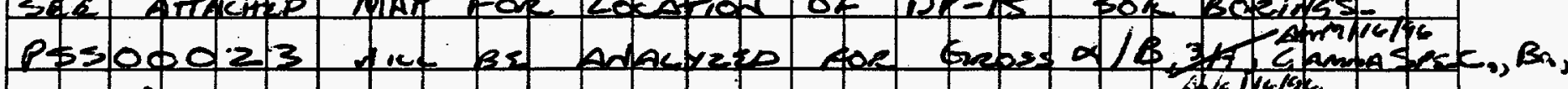

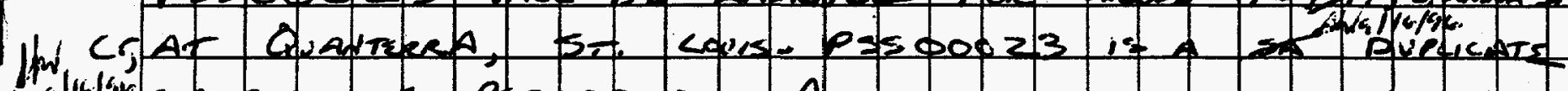

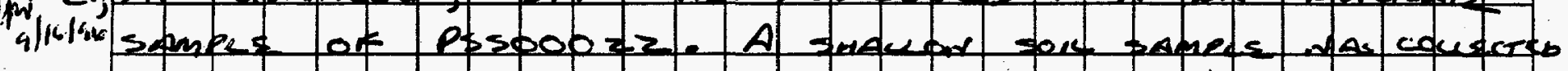

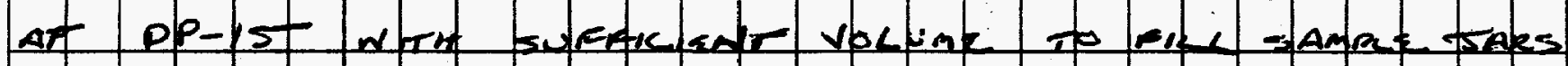

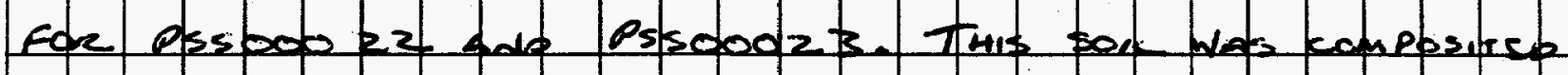

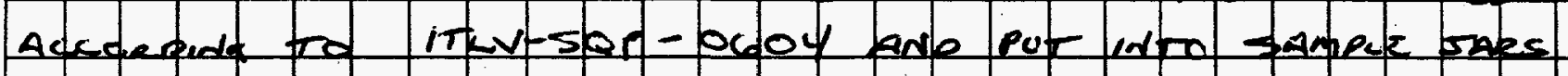

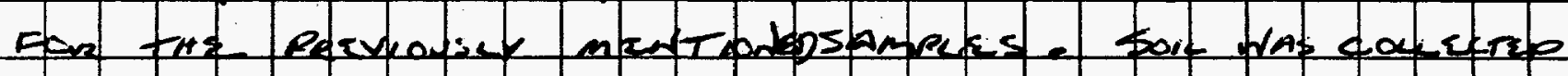

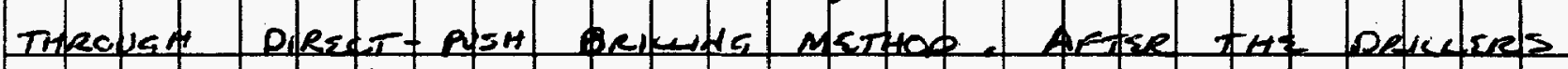

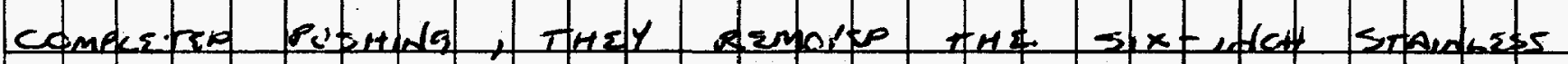

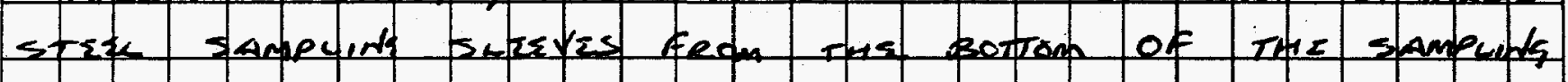

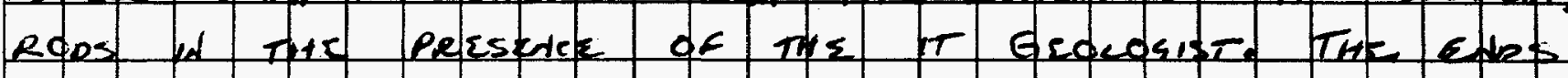

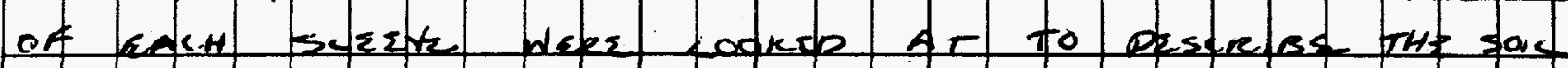

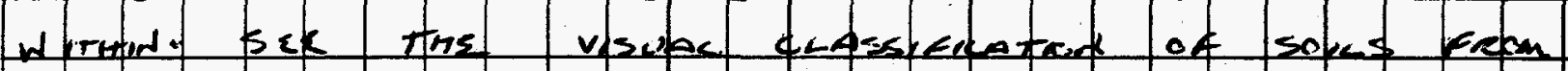

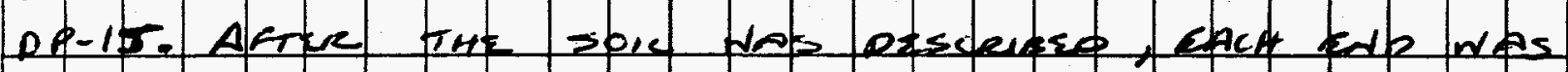

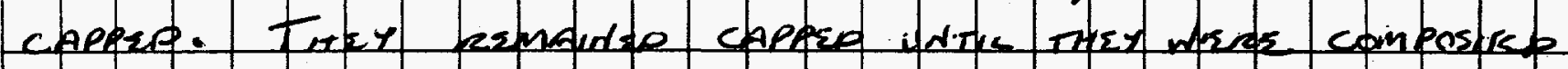

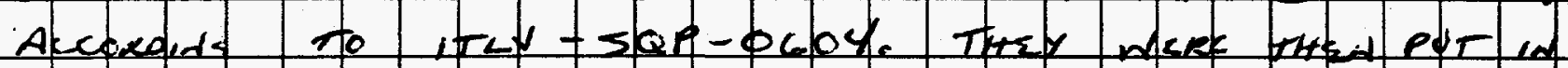

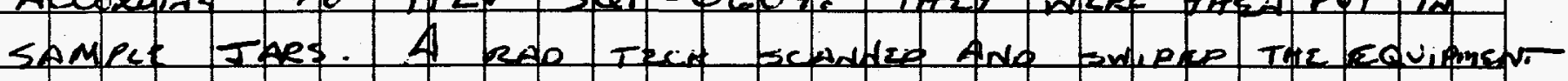

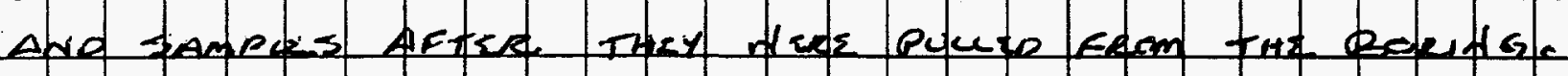

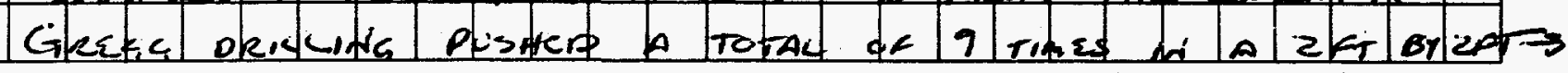

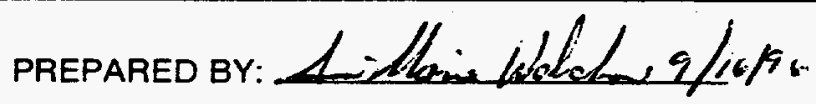


INTERNATIONAL

TECHNOLOGY

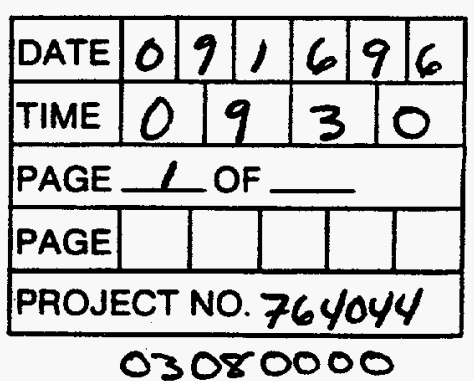

PROJECTNAME - ShOAL Muepit Charactsrization SAMPLENO. PS500026

SAMPLELOCATION_DP $D$ - 16

SAMPLE TYPE SOK - SHACLON

COMPOSITE $\rfloor$ YES NO

COMPOSITE TYPE SPATIAL OF DP-16

DEPTH OF SAMPLE $0-3 \in T$

WEATHER PARTLY SUNAY TLMP YC'S

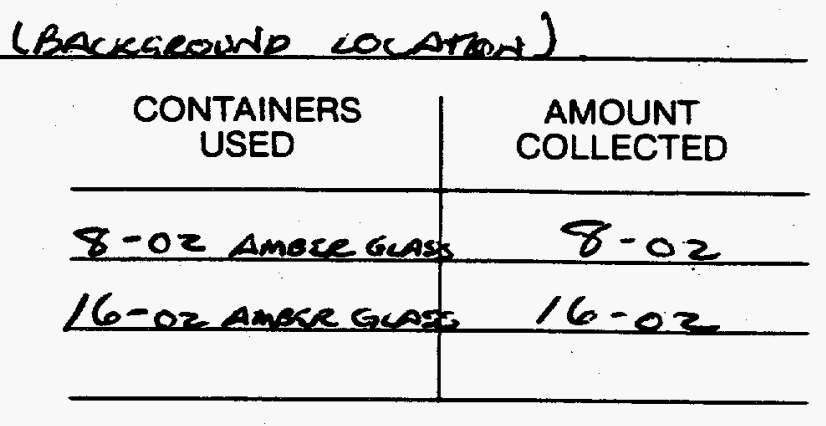

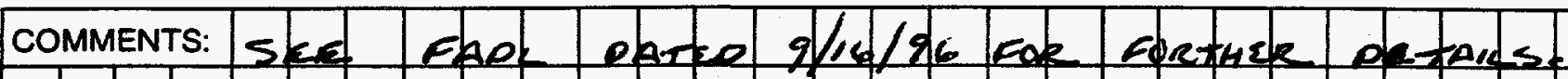

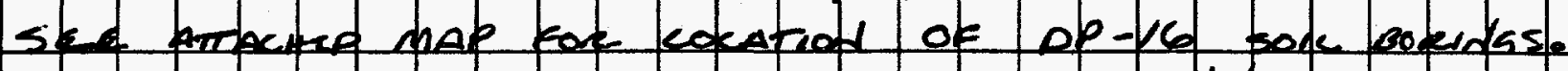

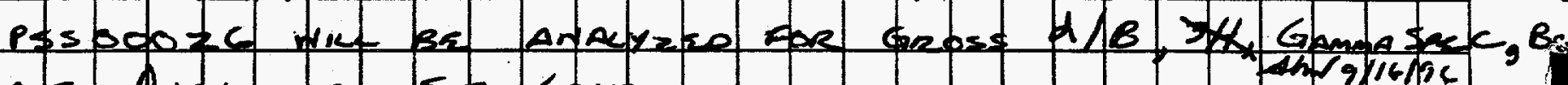

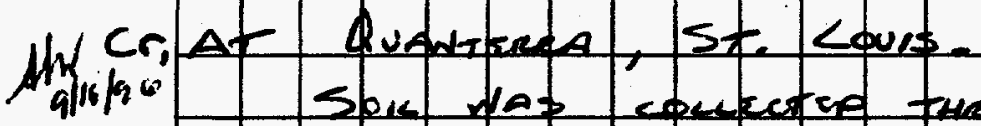

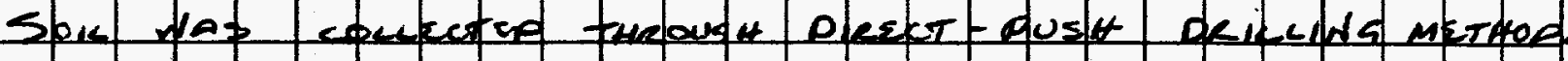

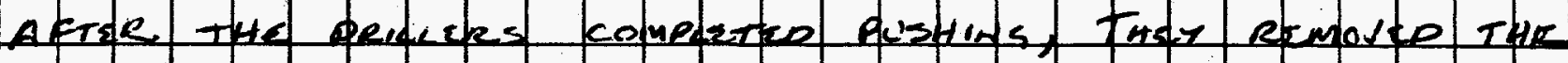

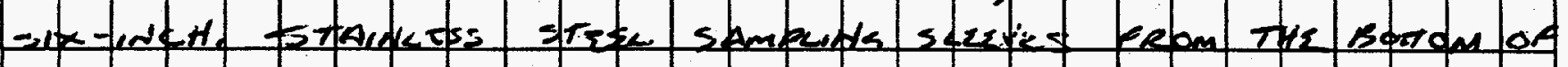

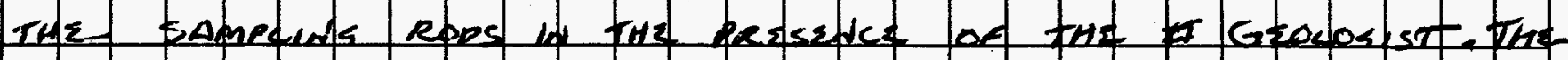

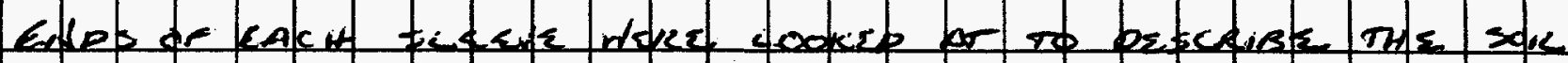

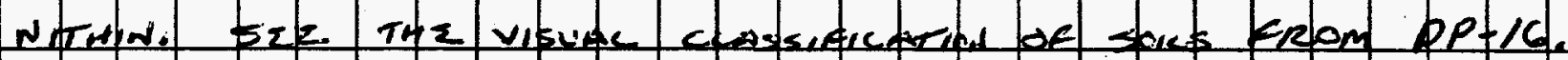

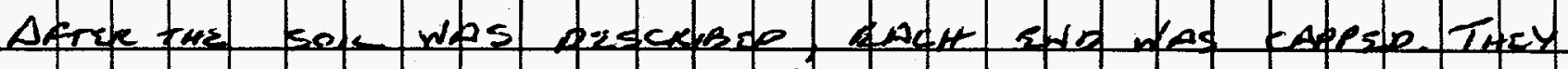

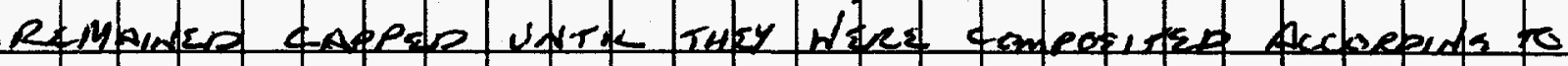

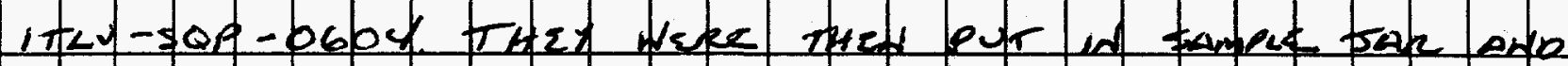

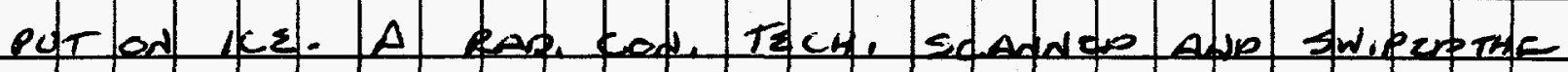

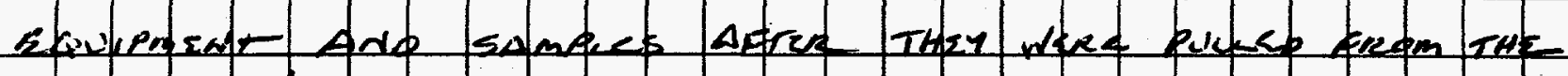

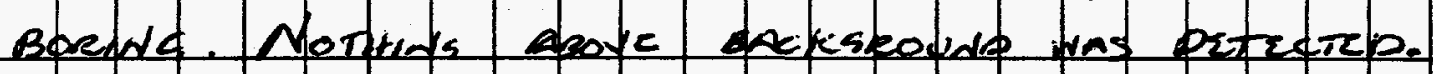

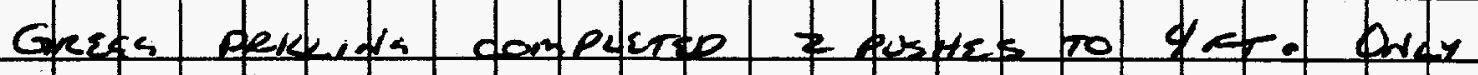

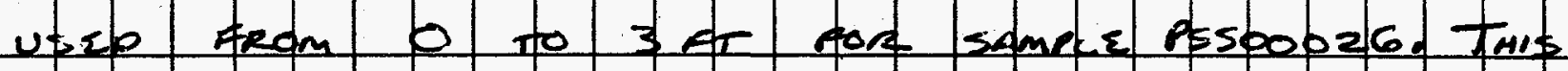

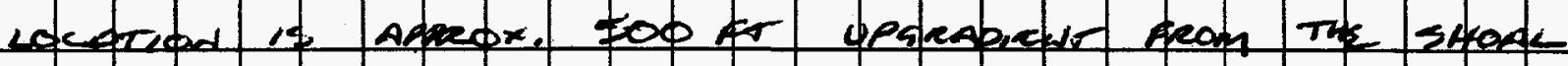
impardanzit.

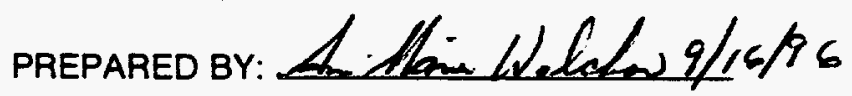


INTERNATIONAL TECHNOLOGY

SAMPLE COLLECTION LOG

\begin{tabular}{|l|l|l|l|l|l|l|}
\hline DATE & 0 & 9 & 1 & 6 & 9 & 6 \\
\hline TIME & 0 & 9 & 5 & 0 \\
\hline PAGE & L & OF \\
\hline PAGE & & & & & \\
\hline PROJECT NO .764044 \\
\hline \multicolumn{4}{|c|}{03080000} \\
\hline
\end{tabular}

PROJECT NAME

SAMPLE NO.

SAMPLE LOCATION

SAMPLE TYPE SOM - SHAWN

COMPOSITE $\downarrow$ YES NO

COMPOSITE TYPE SPATIAL OK DP-17

DEPTH OF SAMPLE $0-3 \leftarrow T$.

WEATHER PARTLY SUNNY, TEMP YO'S
(BACKGROWIO LOCATION)

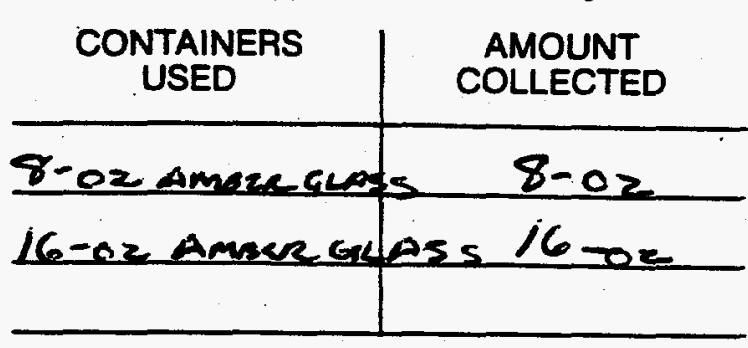

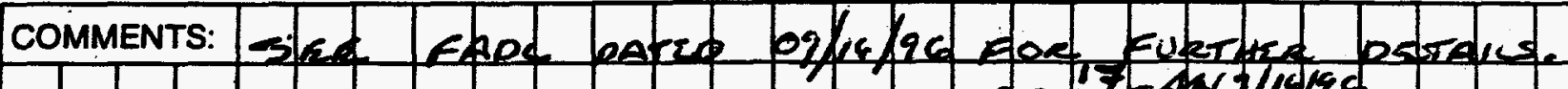

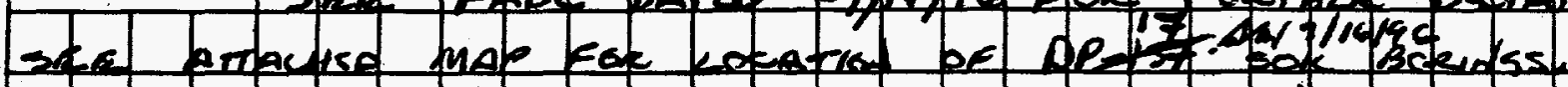

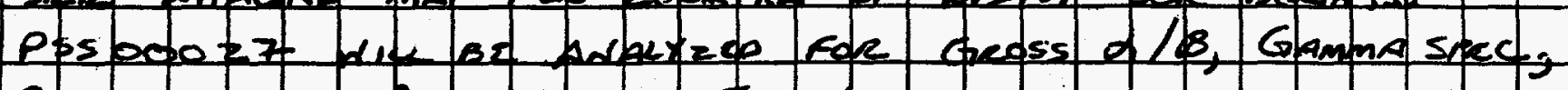

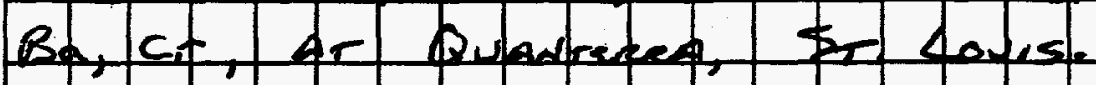

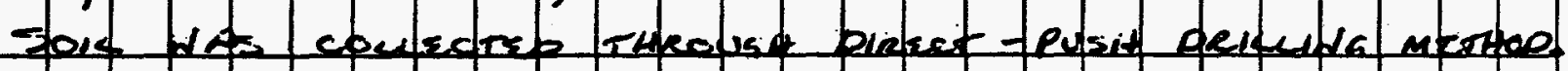

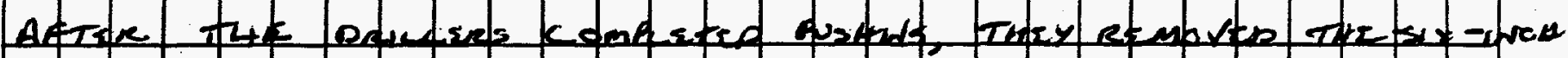

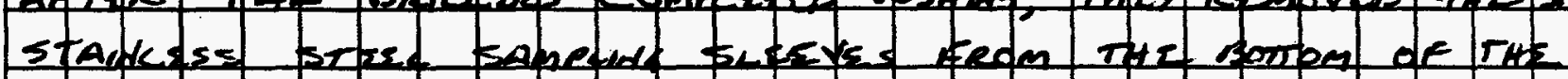

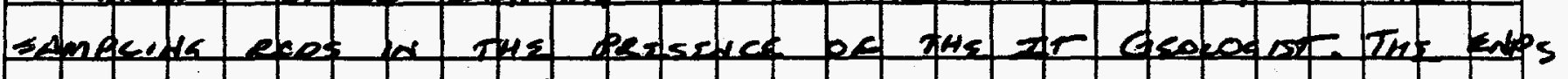

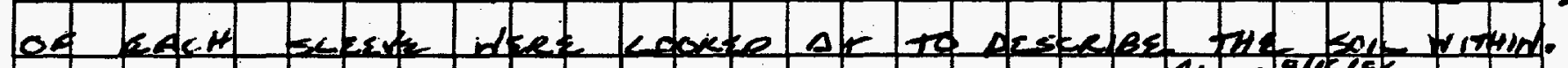

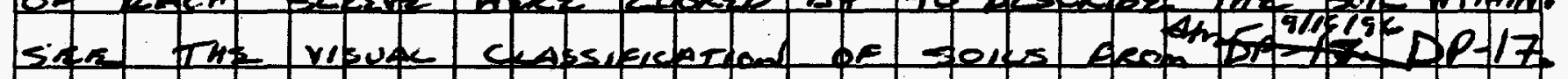

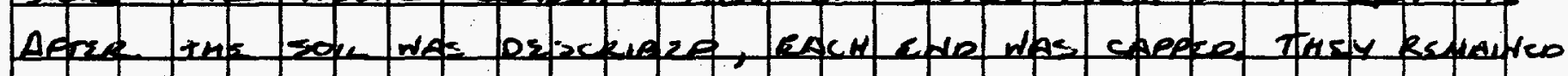

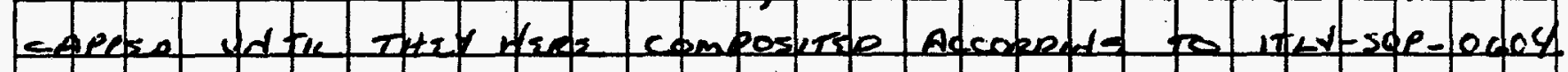

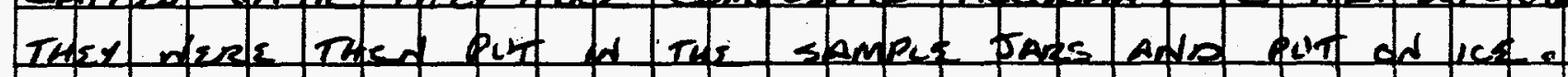

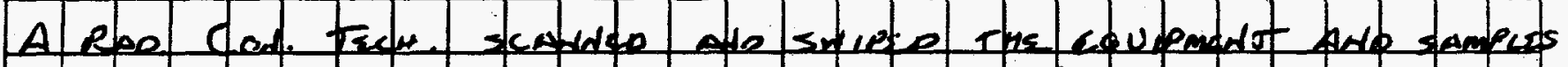

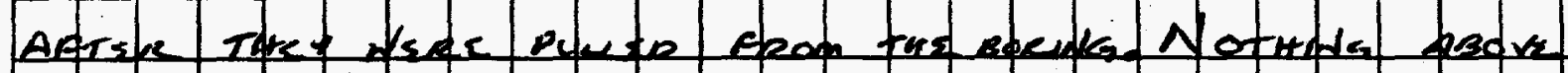

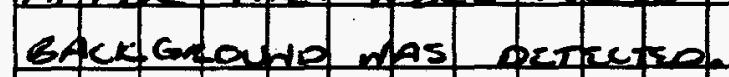

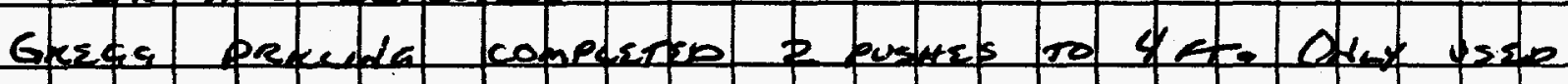

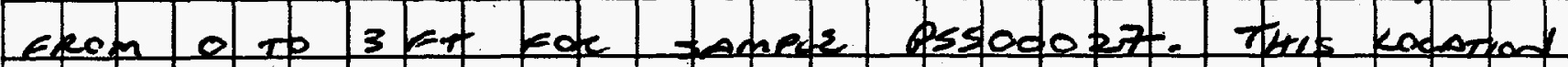

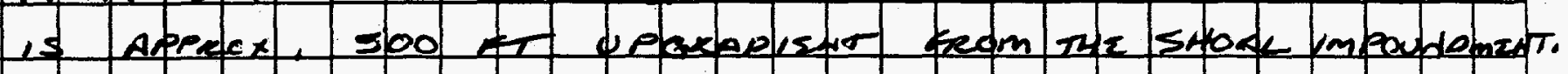

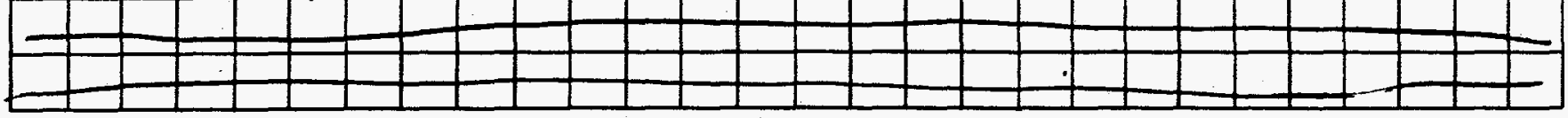

PREPARED BY: L- Main held ow glia/ ic 


\section{APPENDIX B}

\section{HOUSEKEEPING SITE CLOSURE VERIFICATION DOCUMENTATION}




\section{FFACO CORRECTIVE ACTION SITE HousekeEPING Closure VERIFICATION FoRM}

Closure Verification Date: August 19, 1997

CAS Number: 57-98-01

General Location: Project Shoal Area

Latitude: $39^{\circ} 11^{\prime} 56^{\prime \prime}$

Longitude: $118^{\circ} 22^{\prime} 35^{\prime \prime}$
CAU Number: 416

Elevation: $5198 \mathrm{ft}$

Northing: $4,338,653.629$ (UTM)

Easting: $546,682.546$ (UTM)

Coordinate/Elevation Data Obtained from Garmen 40 Global Position System: Accuracy is within $300 \mathrm{ft}$ Horizontal - Vertical Varies with Locality

Site Access Route:

From US 50 turn south on SR 839 approximately 4.9 miles to corrals (on east side of road). Continue 0.1 mile on SR 839, turn west on dirt road and proceed approximately 3.9 miles. Site is approximately 120 feet to the south of the road.

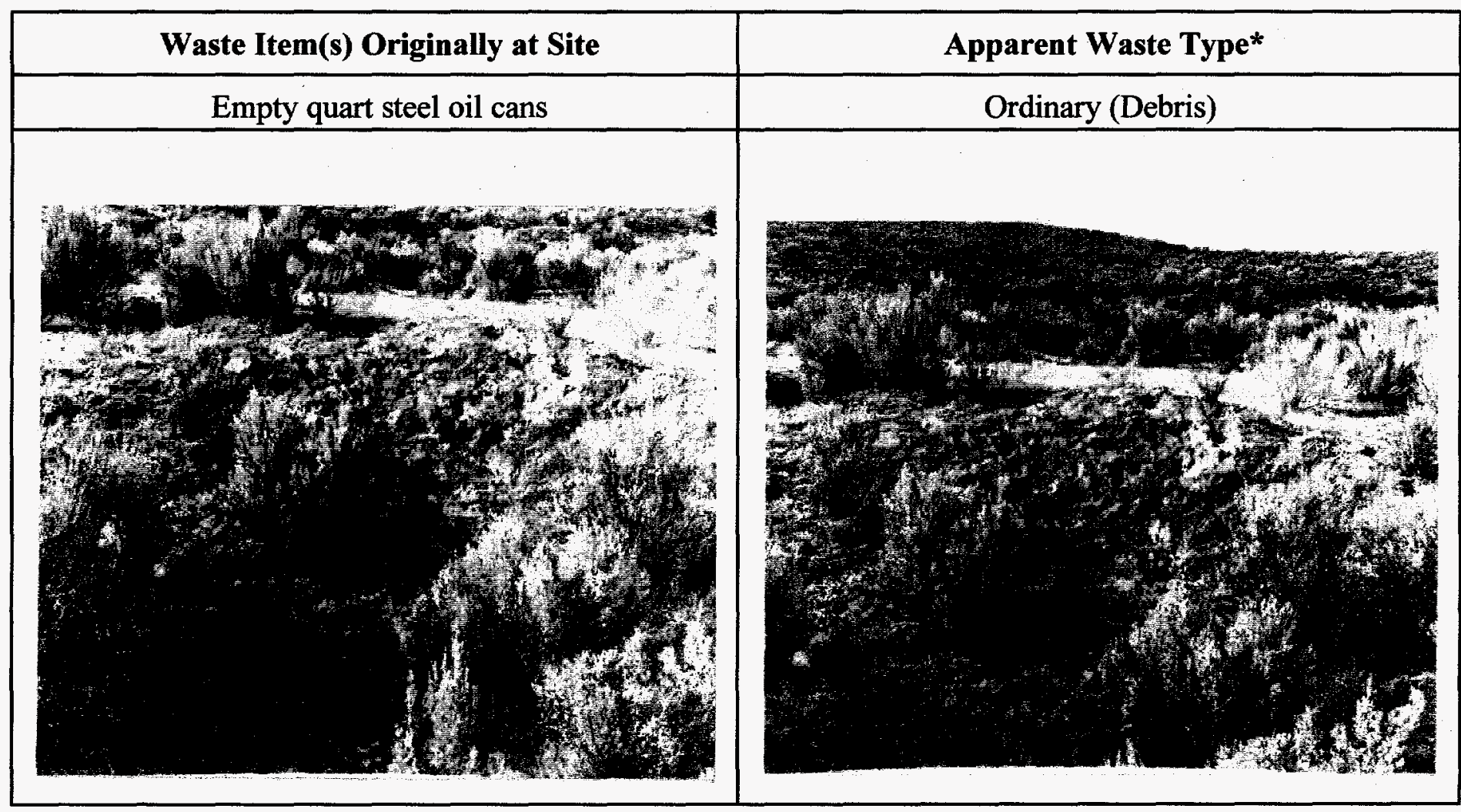

CAS Status Prior To Cleanup

CAS Status After Cleanup

* Ordinary, Scrap Metal, Asbestos, PCB, Salvageable, Hazardous, Radioactive, Mixed, Unknown, Other

\section{Current Site Description/Observations:}

IT Corp. field staff identified approximately six oil cans at the site on March 12, 1996, BN Environmental

Remediation (ER) staff verified that the oil cans (and approx. 14 more in the same general area) were still present 


\section{FFACO CORRective ACtion Site Housekeeping Closure VERIFICATION FORM}

Current Site Description/Observations (continued):

on August 19, 1997. ER staff retrieved the cans on August 19, 1997 (approximately 20) for disposal at the solid waste landfill located at the Nevada Test Site.

$\checkmark \quad$ No Further Action Required at Corrective Action Site

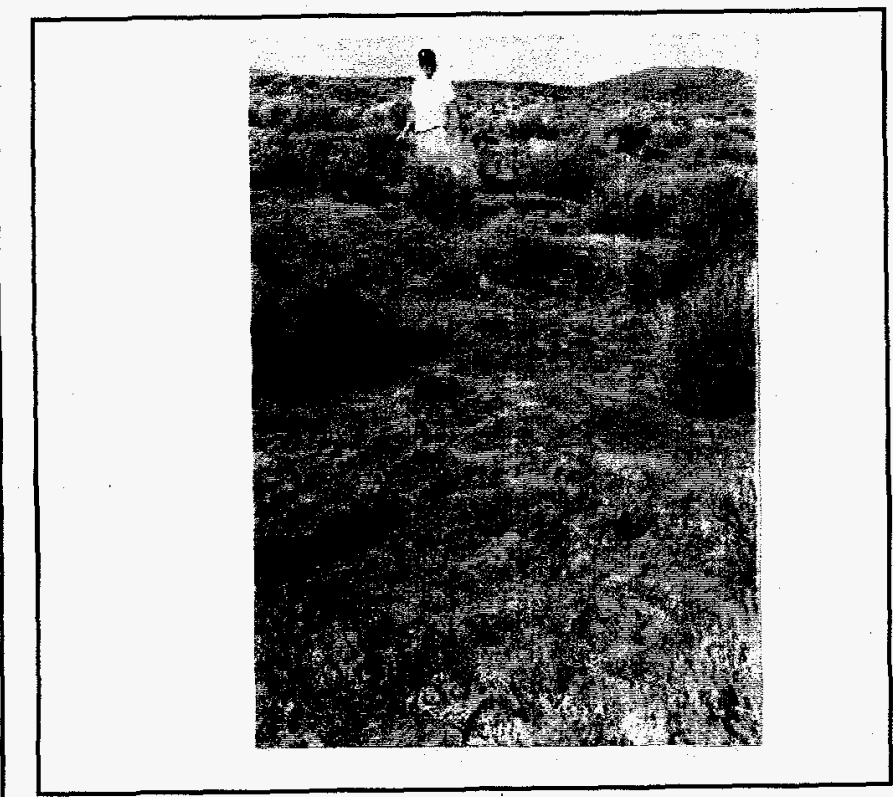

CAS Status Prior To Cleanup

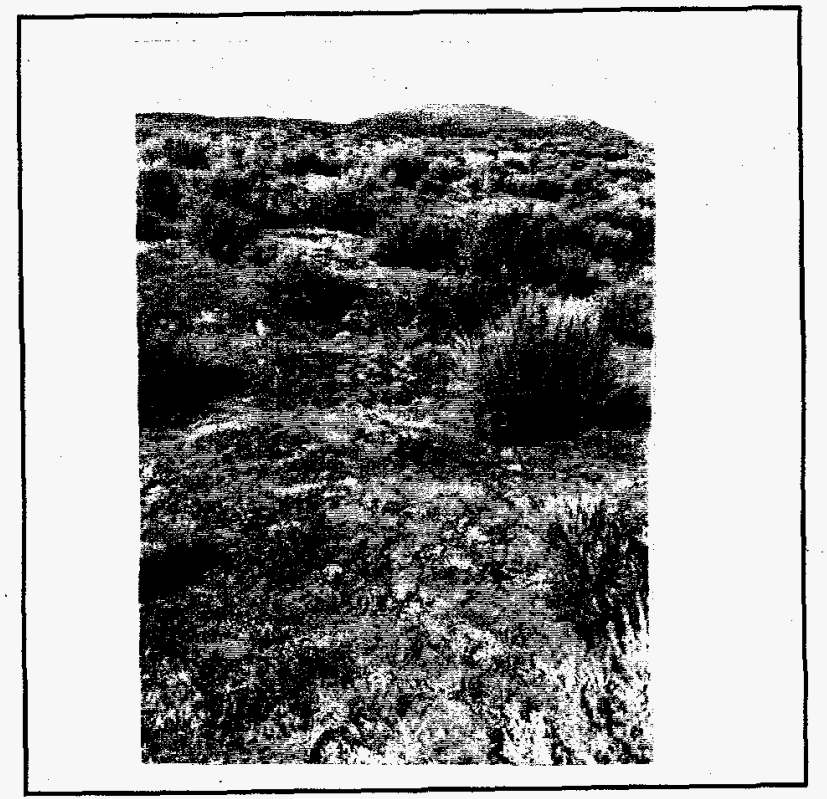

CAS Status After Cleanup

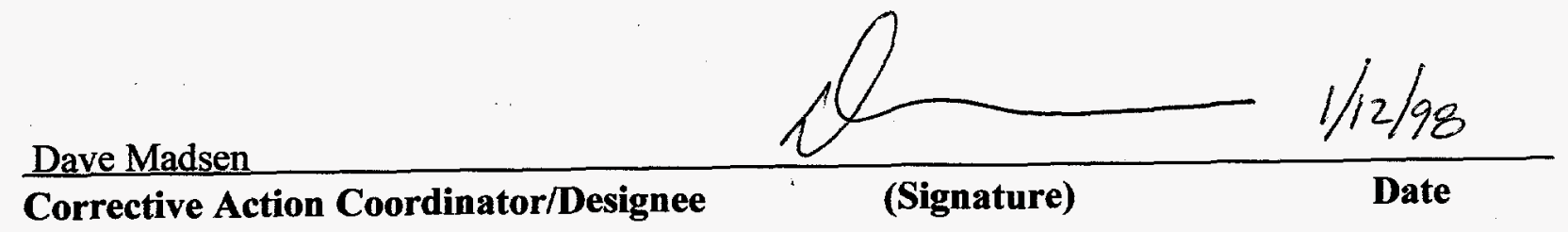

Page 2 of 2

CAU 416, CAS 57-98-01 
DATE:8-19-97 No. 4 .

Reynolds Electrical \& Engineering Co., inc. Radiological Control Department-Ramatrol

Material Clearance MONITOR: $\mathrm{Mc}$ Closkey ORGANIZATION: BN RP SURVEY LOCATION: PROJECT SHOAL FROM:PROJECT SHOAL - FAllOW NV TO: NS

XUNRSTRICTED

DOFF-SITE

ONSITE

SALVAGE

EXCESS

THE MATERIAL HASBEENSURVEVEDFOR
RADIOACTIVTY AND MEETS DOE
STANDARDS FOR REESE TO PUBIC
USE

CONTROLLED

DESCRIPTION:

BAG OF OLD RUSTY OIL CANS PICKED uP FROM proser shOAL AREA VIC GAllON NV.

CAM 416 CAS57-98-01

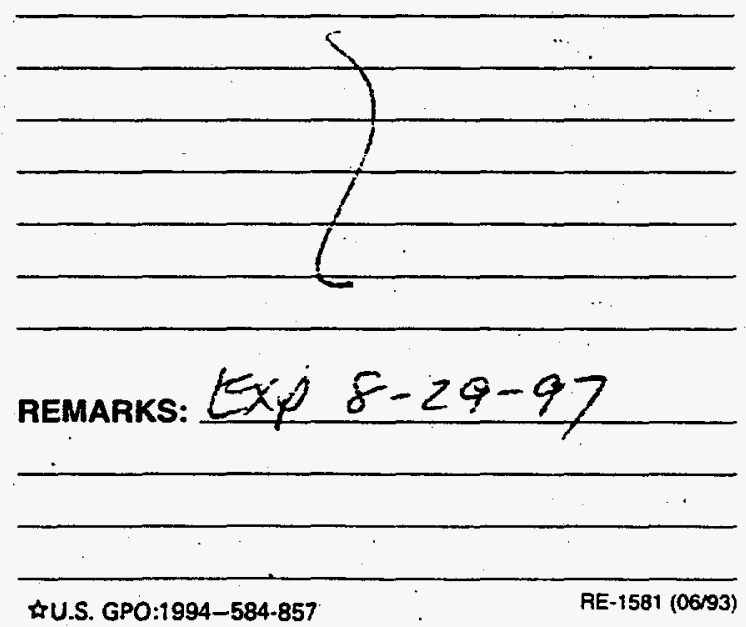




\section{APPENDIX C}

\section{WASTE DISPOSAL DOCUMENTATION}




\section{AREA 6 HYDROCARBON LANDFILL ACCEPTANCE CHECKLIST}

SOURCE OF MATERIAL.
a. Generator:
b. Contact and phone \#:
c. Location:

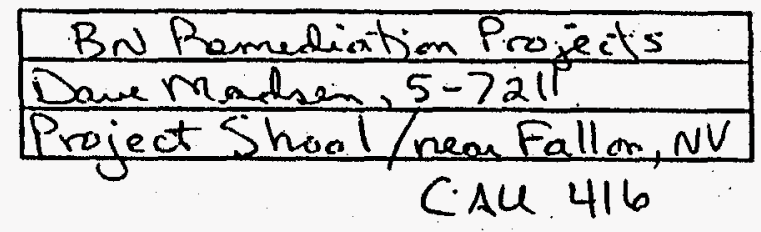

d. Charge \#:

e. Organization code:

f. Who will transport?

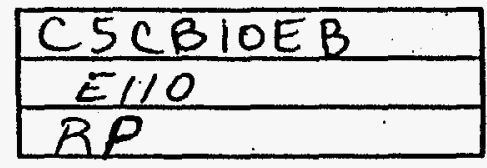

PACKAGE WILL INCLUDE THE FOLLOWING ITEMS
a. Characterization letter
b. Analytical results
c. Process knowledge
d. Is the package complete?
e. Basic description

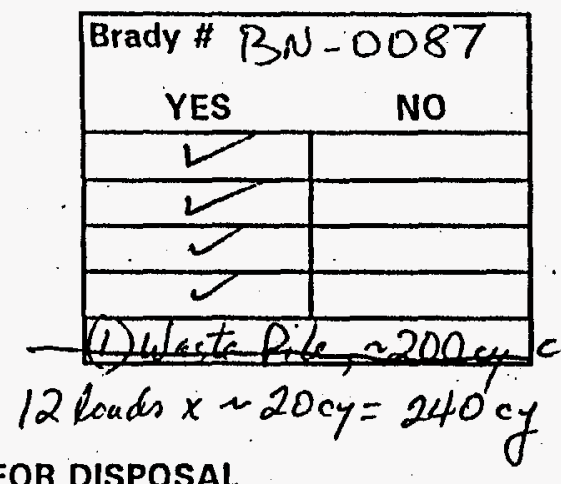

\begin{tabular}{|c|c|}
\hline $\begin{array}{c}\text { Brady \# } \\
\text { YES }\end{array}$ & NO \\
\hline & \\
\hline & \\
\hline & \\
\hline & \\
\hline & \\
\hline & $3 / 29 / 97$ \\
\hline
\end{tabular}

\begin{tabular}{|c|c|}
\hline $\begin{array}{r}\text { Brady \# } \\
\text { YES }\end{array}$ \\
\hline & NO \\
\hline & \\
\hline & \\
\hline & \\
\hline
\end{tabular}

\begin{tabular}{|c|c|}
\hline $\begin{array}{c}\text { Brady \# } \\
\text { YES }\end{array}$ \\
\hline & \\
\hline & \\
\hline & \\
\hline & \\
\hline & \\
\hline
\end{tabular}

SCHEDULE A DATE AND TIME FOR DISPOSAL

$8 / 25 / 97=6$ lo

$8 / 26 / 97=6$ loads $=326,900 \#$
a. Date scheduled:
b. Start date:
c. End date:

\begin{tabular}{|l|}
\hline $7-2-97$ \\
\hline$\frac{8-11-97}{8-26-97}$ \\
\hline
\end{tabular}

d. Drum \#'s:

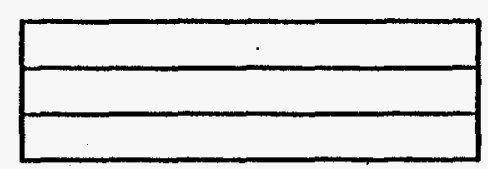

AT THE LANDFILL, THE GENERATOR MUST HAVE
a. Bill of Lading
b. Rad certification
c. Weight ticket
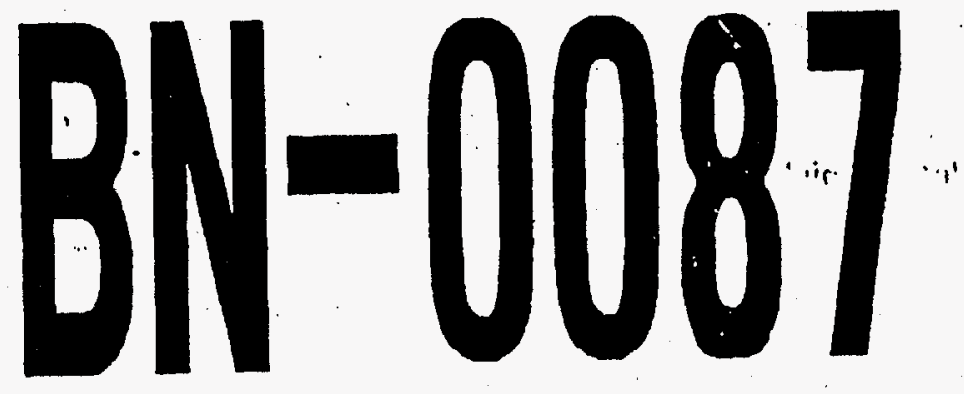

E5T. $614,900 \#$

\section{COMPLETE PACKAGE}

a. Enter weight into database

b. Enter into billing log

\begin{tabular}{|l|l|}
\hline YES & NO \\
\hline $8 / 29 / 97$ & \\
\hline
\end{tabular}

Signature/Date: $(9 \log 2 / 8-29-92$ 
DATE: $8 / 25 / 97 a^{3}$ No. A 5791

Reynolds Electrical \& Engineering Co., Inc. Radiological Control Department-Ramatrol

\section{Material Clearance}

MONITOR:

ORGANIZATION: $\frac{B N R P}{\text { SURVE LOCATION: PROJECT SHOAL }}$

ncCloskey

FROM: PROTECT SLTOAL

TO: NTS

¿UNRESTRICTED

$\triangle$ OFF-SITE

$\square$ ON-SITE

$\square$ SALVAGE

$\square$ EXCESS

THS MATEREAL HAS BEEN SURVEYED FOR RADIOACTIVTY AND MEETS DOE STANDARDS FOR RELASE TO PUBLIC USE

CONTROLLED

DESCRIPTION:

typRocanson

Soiv plom profiect Sitonl - Fallon uV.

CAM 416

Waste Traching \#BN0087" 6 loads of soil

REMARKS: Exp, q-20-97
DATE: 8/26lat: No. A 5792

Reynolds Electrical \& Engineering Co., Ine. Radiological Control Department-Ramatrol

\section{Material Clearance}

Monitor:- McCloskey ORGANIZATION: $B N R P$

SURVEY LOCATION: SITOAL MUDPIT

FROM: PIZUSEET SHOAL SITE TO: NTS

\section{DUNRESTRICTED \\ 区OOFF-SITE \\ $\square$ ON-SITE \\ $\square$ SALVAGE \\ $\square$ EXCESS}

THUS MATERIAL HAS BEEN SURVEYED FOR RADIOACTIVIT AND MEETS DOE STANDARDS FOR REEASE TO PUBLC USE

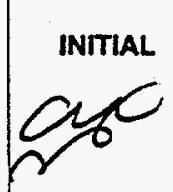

\section{$\square$ CONTROLLED}

DESCRIPTION: HYOROCARBON (Petrolenm) Impaetel Sorl From Project Slical Mind Pit - CAU 416

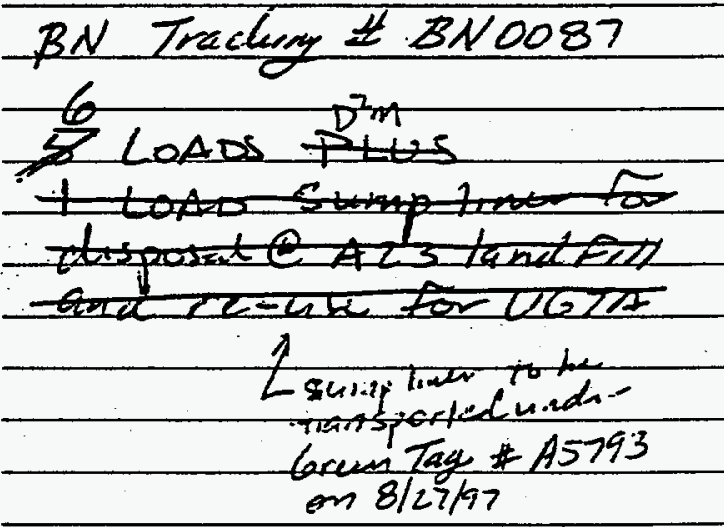

REMARKS: EXp $9-20-97$ 
PUBLIC WEIGHMASTER'S CERTIFICATE OF WEIGHT AND MEASURE This is 20 certify. That the following - described matchandise was wighad by a Public

Weighmaster as prescribed by the Public Weighmaster Law. NRS. Chapter 582 ceoss

87340 LU 8520 H $8-25-77$

Teqpe.

NET

4

$+$

\section{SMEDLEY'S}

ITSS REMOMIGHWAY PHONE (TOS! A3 3900 EALLON. NEVAOA HeCOS

Dele $1,1 \%$

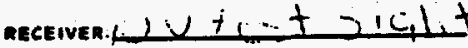

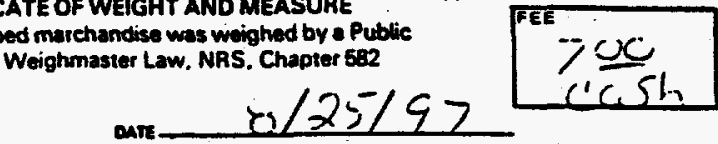

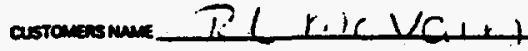

nooness i.i.icted Sul

\begin{tabular}{|c|c|}
\hline EOUIPMENT NO. & TRUCK LICEMSE NO. \\
\hline - & $\therefore 33$ \\
\hline TRAILER LICENSE NO & $\begin{array}{l}\text { DRIVER ON } \\
\text { DRIVER OFF }\end{array}$ \\
\hline Daver $t_{0}$ & \\
\hline
\end{tabular}

SMEDLEYS

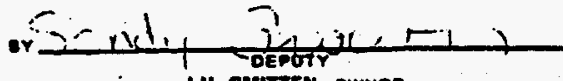

dit. sentren - ownen

$1957 / 28820$

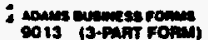

INIFORM STRAIGHT BILL OF LADING Original-Not Negotiable-Domestic

Shipper's:

Carrier

moent's No.

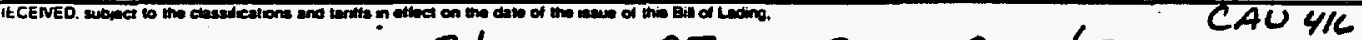

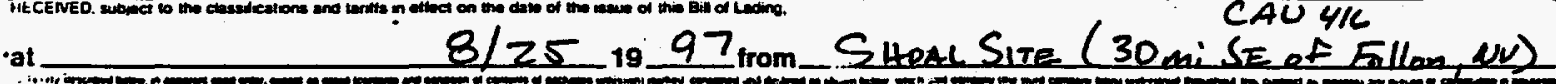
$\therefore=-2=0-000$ (Mall or street codress of conaloneo-for purposes of motilieation only.) Consigned to BECHTIZL NEvadA (FOR DOE/NU) Destination NEuAD TEST SITE (NTS) State of NV Zio Code County of NYE

Routing Delivering Mclate Vehicle ollect On Delivery and remit to: or Car Initial

C. 0. 0. chares ( Stippar
to ba paid by $\quad\{$ consigua Subiect so section 7 a constions :" this atherment is io be detrent in ins

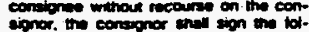
sipnor. the consog

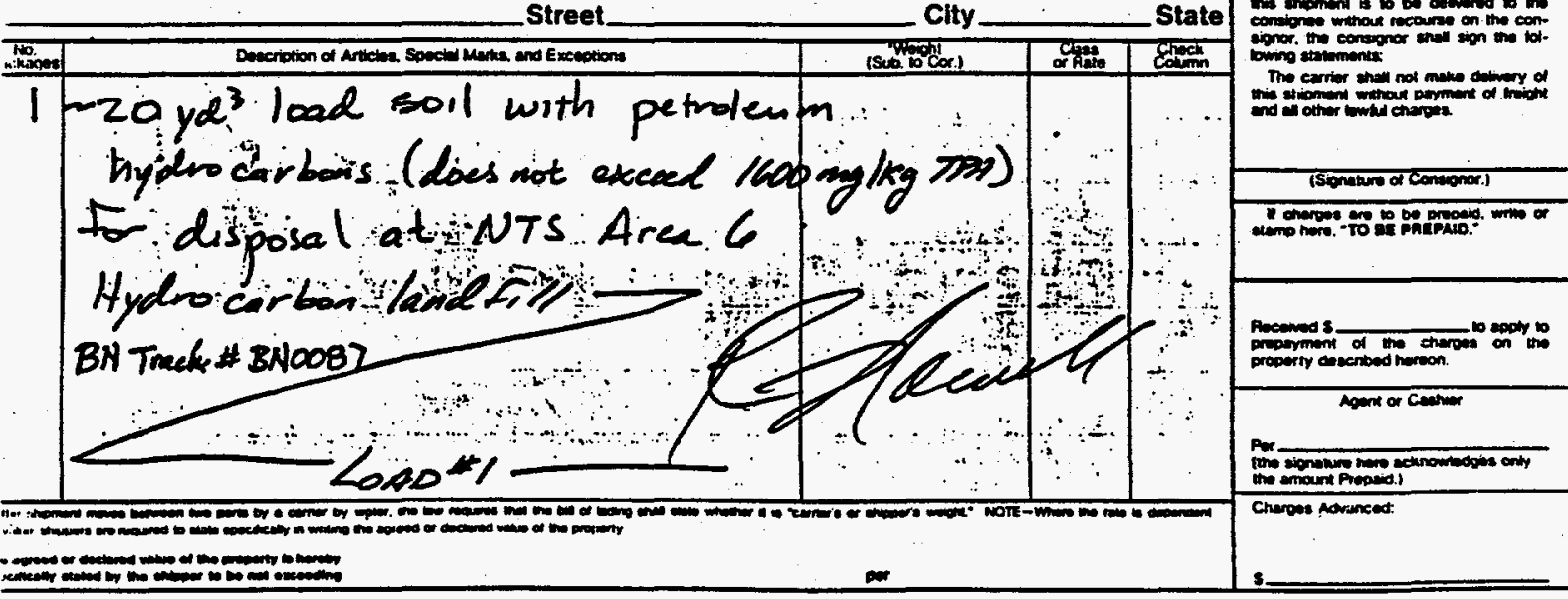

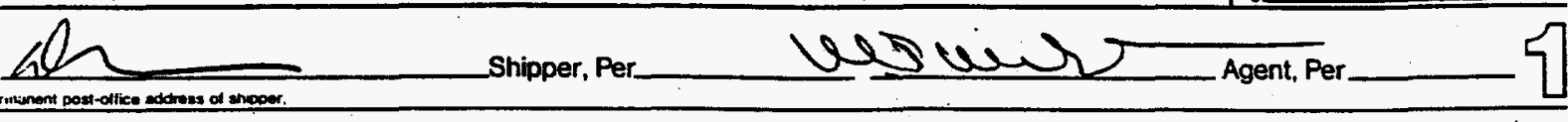




\section{STATE OF-NEVADA}

PUBLIC WEIGHMASTER'S CERTIFICATE OF WEIGHT AND MEASUAE This is to centity. That the following - described marchandise was weighed by a Public

Weighmester as prescribed by the Public Weighmaster Law. NAS. Chapter 582

78980 LS 8132A 8-25-97

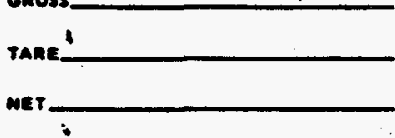

\section{SMEDLEY'S}

IISS RENO MIGMWAY DHONE (1902) S33 $\$ 300$ FALLON, NEVADA NEOK

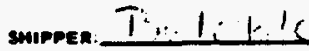

neceIver: $: 11+:-1=1$

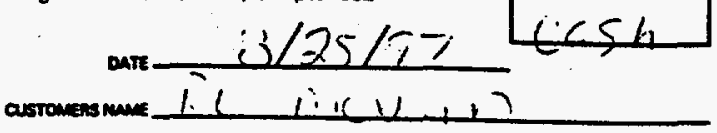

aconsss

conenoorr i, i $t, \ldots i l$

\begin{tabular}{|c|c|}
\hline EOUITMENT NO- & TRUCK LICENSE MO \\
\hline TRAILER LICENSE NO.' & $\begin{array}{l}\text { OAIVER ON } \\
\text { ORIVER OFE }\end{array}$ \\
\hline Donger & \\
\hline
\end{tabular}

SMEDLEYS
PUELIC WEIGHAMATER

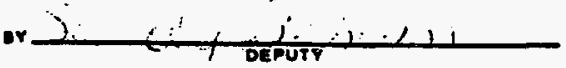

1. 15\$7'20620

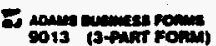

UNIFORM STRAIGHT BILL OF LADING Original-Not Negotiable-Domestic

Shipper's:

Carrier

Moni's No.

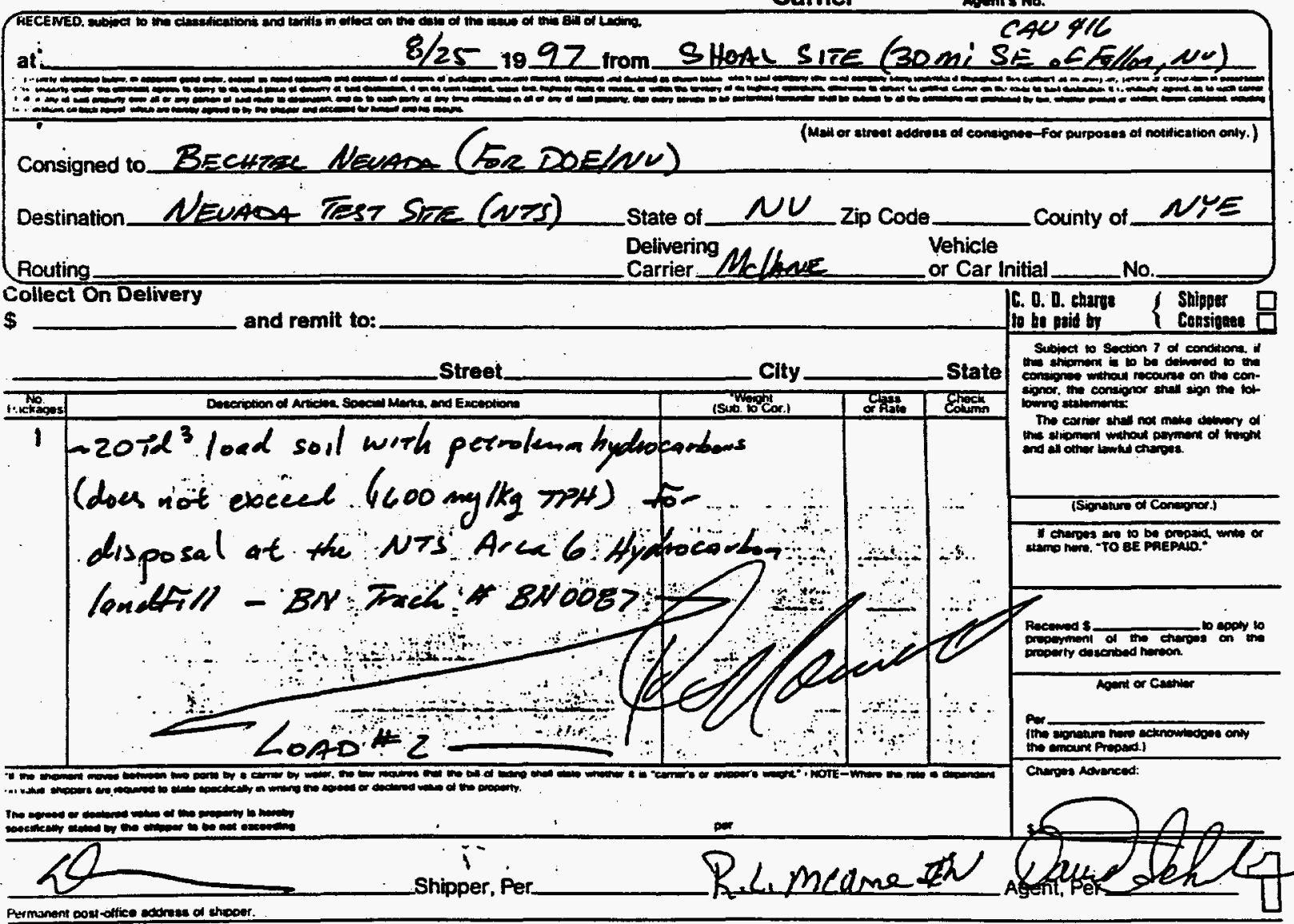




\section{STATE OF NEVADA}

PUBLIC WEIGHMASTER'S CERTIFICATE OF WEIGHT AND MEASURE This is to certify. That the following - described marchandise was weighed by a Pubtic Weighmaster as prescribed by the Public Weighomaster Law. NAS, Chapter 582

79980 LE $8232 A \quad 8-25-97$ anoss

Take.

wer.

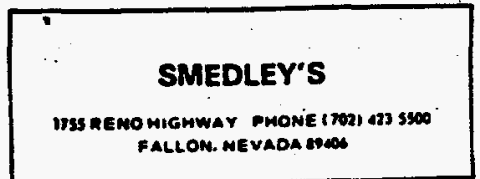

smorex: Belchle neceiven: $\triangle V V+E S t$ Sicht
No. 68179 $\left[\begin{array}{c}70 \\ \text { cash }\end{array}\right]$

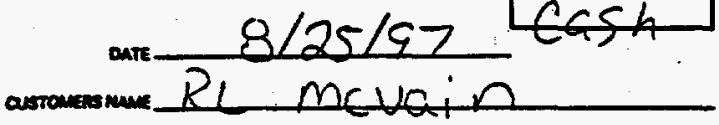
nooness

comporr lont 5oil_ no. of unirs.

\begin{tabular}{|l|l|}
\hline EOUIFMENT MO. & TRUCK UICEMSE NO. \\
\hline & $\vdots$ \\
\hline TRMILER LICENSE NO. & $\begin{array}{l}\text { ORIVEN ON } \\
\text { DRIVER OFE }\end{array}$ \\
\hline ORIVER & \\
\hline
\end{tabular}

SMEDLEY'S

PUBLIC WEIGHMASTE

054531/20020

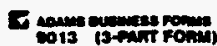

UNIFORM STRAIGHT BILL OF LADING Original-Not Negotiable-Domestic

Shipoer's :

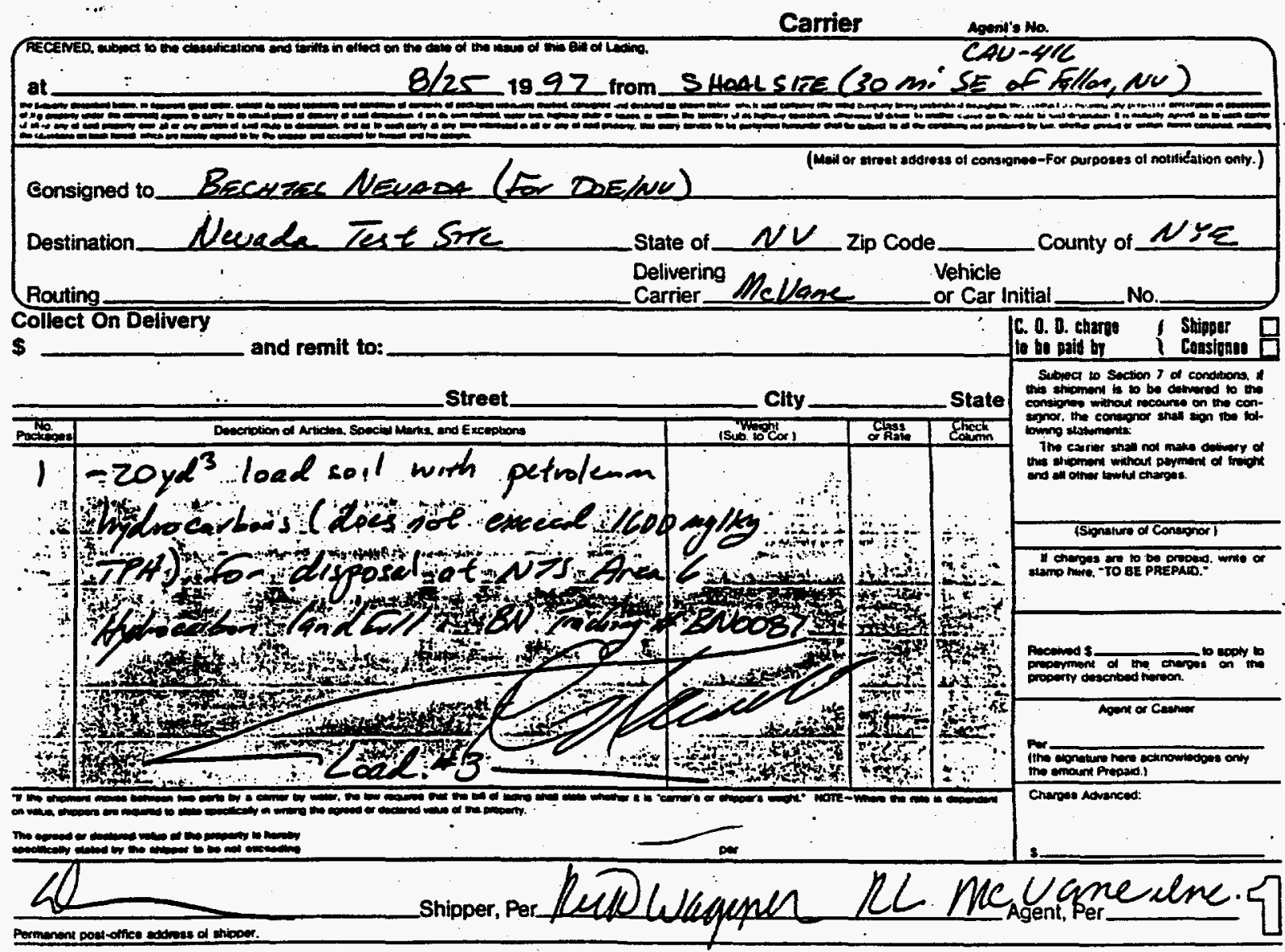




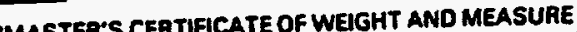

PUBLIC WEIGHMASTER'S CERTIFICATE OF WECHT AND weighed by a Public This is to certify. That the following - described Weighmaster Law. NRS. Chapter 592

cross 3400 L 88364 8-25-97

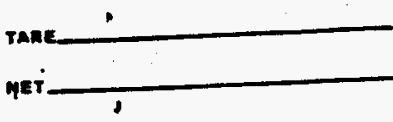

\section{SMEDLEY'S}

19SS RE NOMIGHWAY MONE (roz) 4233500 FALLON. MEVAOA 0000

\section{Hio. 68180}

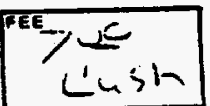

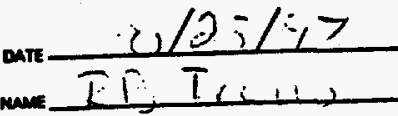

nocosss

commoorr $(2)+1.50) /$ mo of unirs.

\begin{tabular}{|l|l|}
\hline EOUIPMENT NO. & TRUCK LICEMSE MO. \\
\hline & \\
\hline TRAILER LICENSE NO. & $\begin{array}{l}\text { ORIVER ON } \\
\text { ORIVER OFF }\end{array}$ \\
\hline DRIVER & \\
\hline$j$ & \\
\hline
\end{tabular}

DUDLIC WEICHMUSTEN

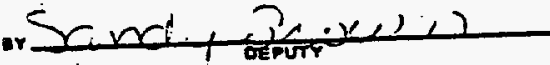
J.H. EMITEN - OWME:

954551/20s20

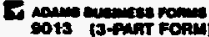

UNIFORM STRAIGHT BILL OF LADING Original-Not Negotiable-Domestic

Shlpopro

Carrier

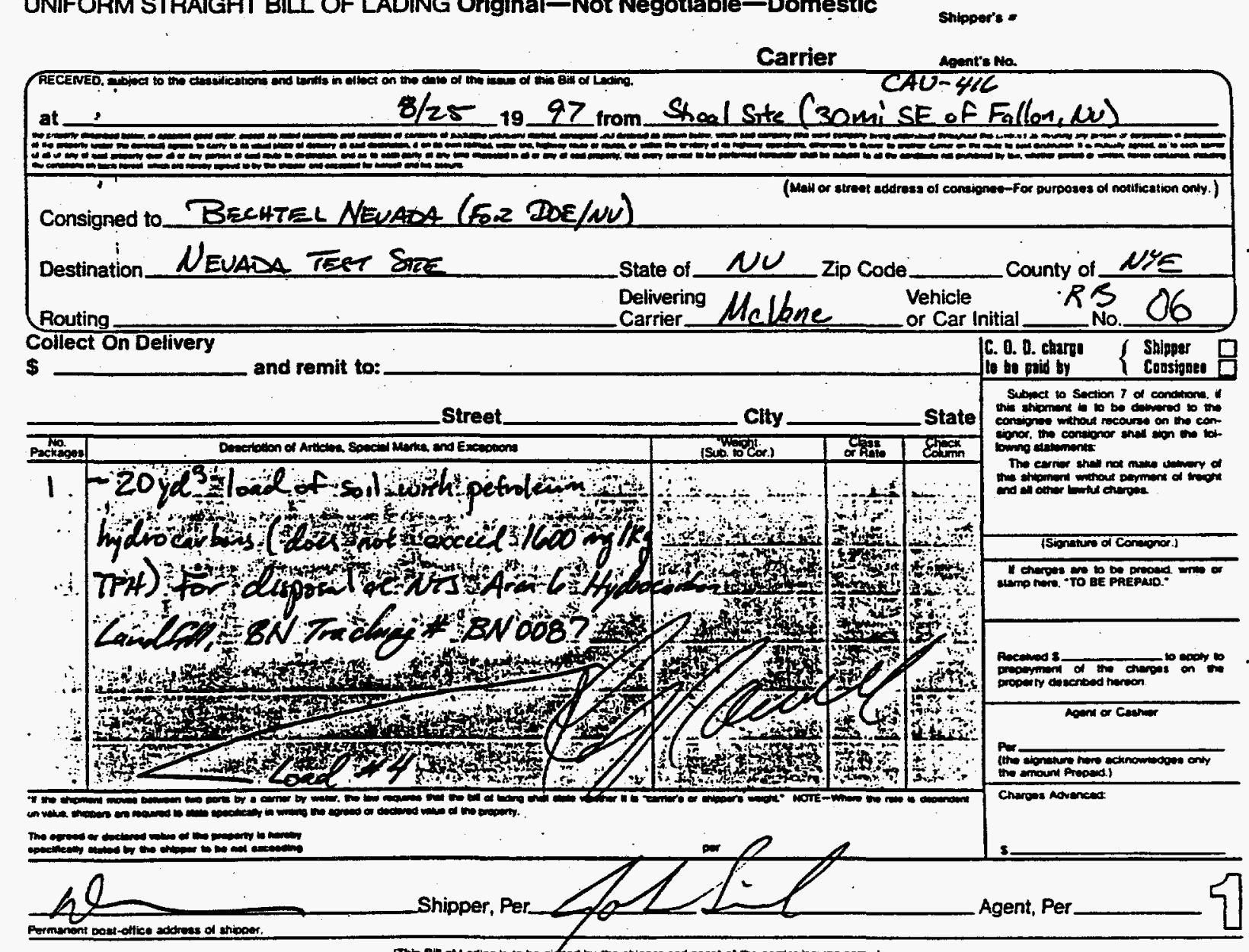
Agent's No.

Mirpen: $\frac{1 \in I C 15}{i j ; T-j 15 L_{1} t}$




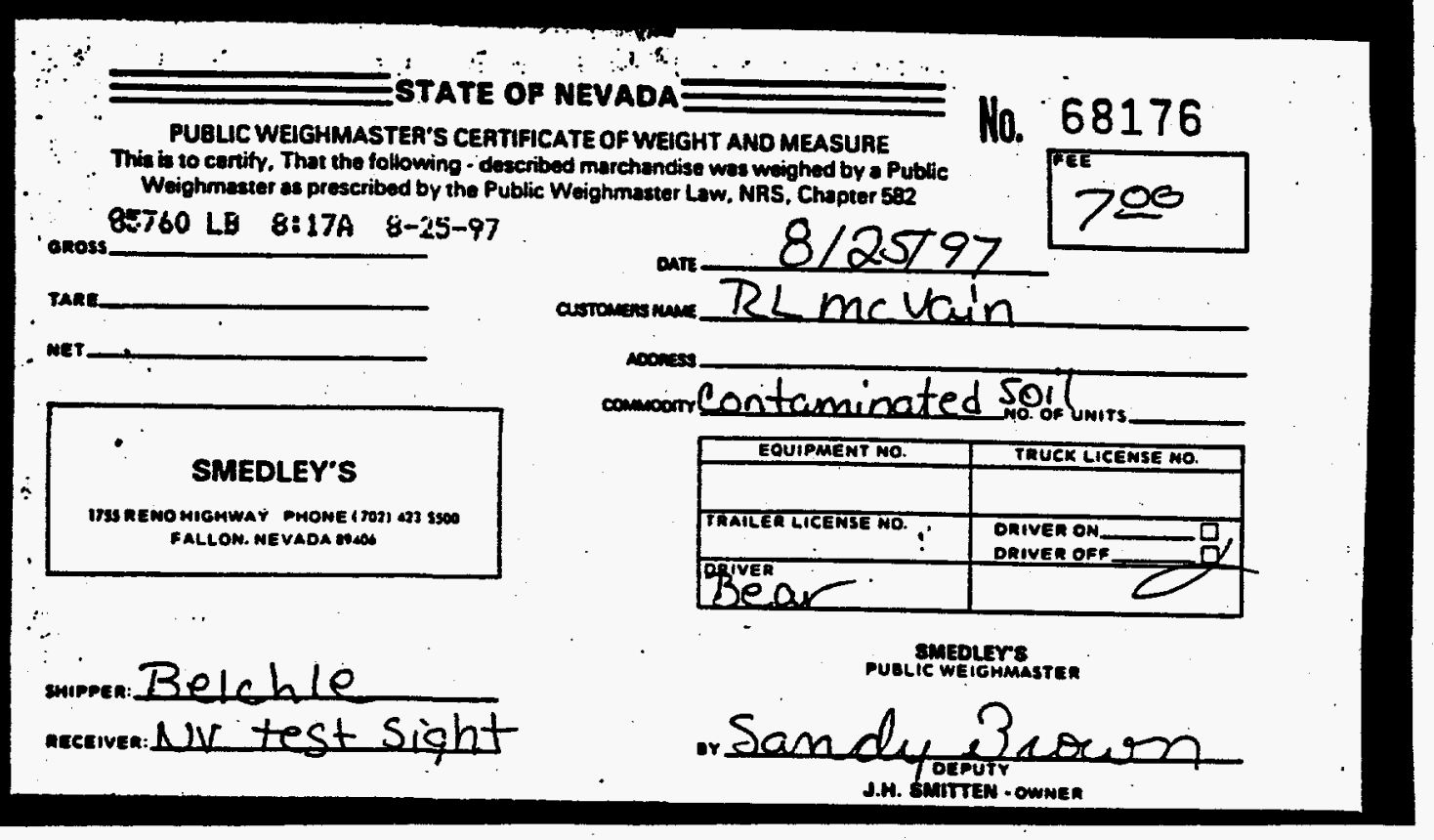

054557/28620

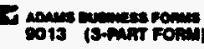

UNIFORM STRAIGHT BILL OF LADING Original-Not Negotiable-Domestic

Shipper's :

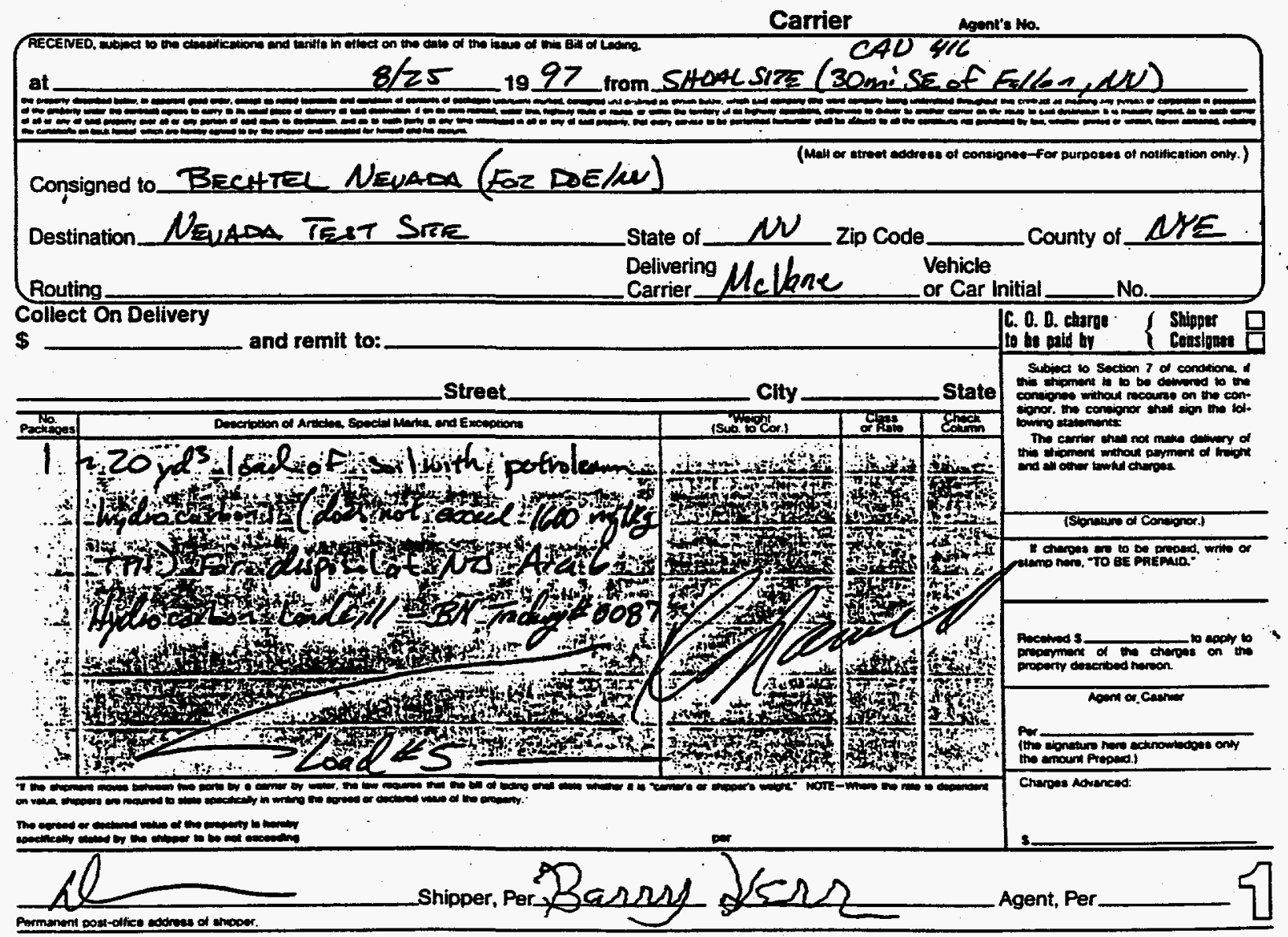




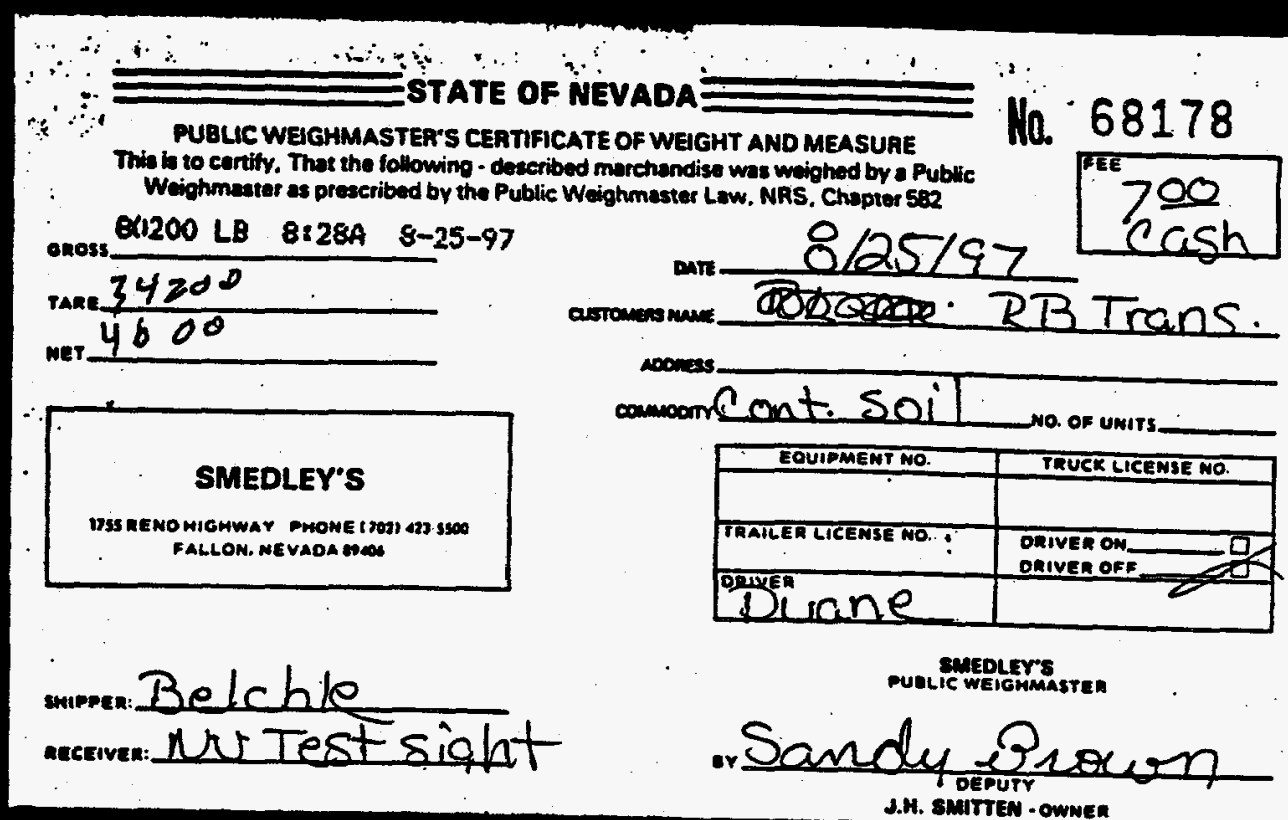

954557720020

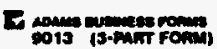

UNIFORM STRAIGHT BIL OF LADING Original-Not Negotiable-Domestic shipow's

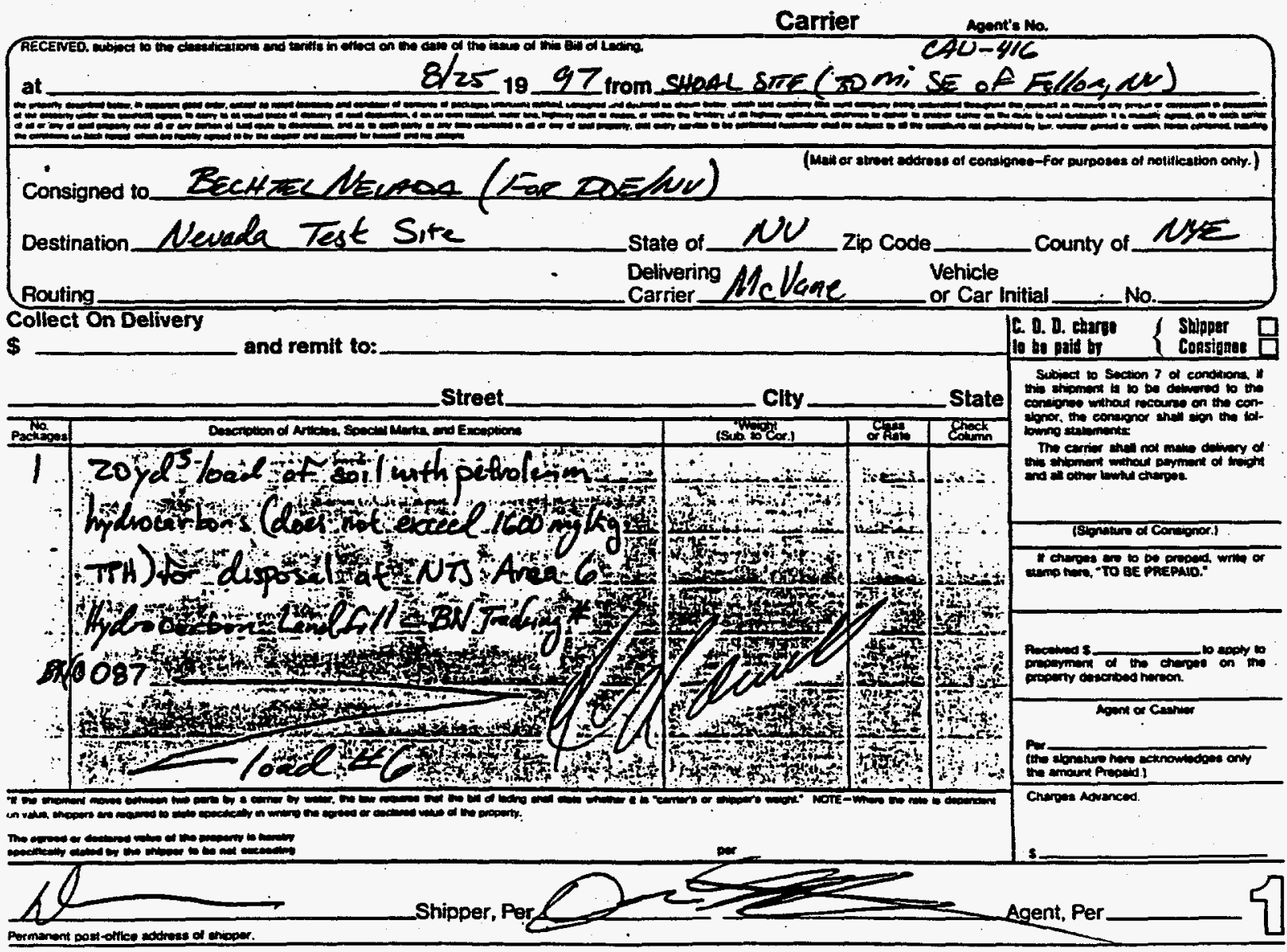




\section{$\cdots$}

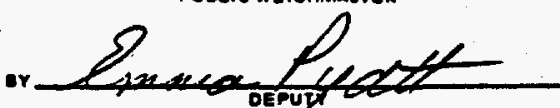

IH. SMirth -ownen

954557/28620

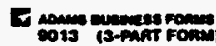

UNIFORM STRAIGHT BILL OF LADING Original-Not Negotiable-Domestic

Shipper's.

Carrier

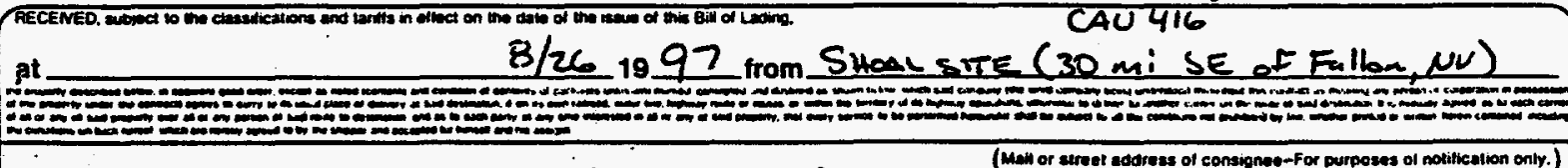
Consigned to Becutal Nevad (For DoE/Ww)

Destination NeUAOA TEST SuTe State of NU Zip Code

Routing

Collect On Delivery

s Delivering Mellave

Vehicle

County of NYE and remit to:

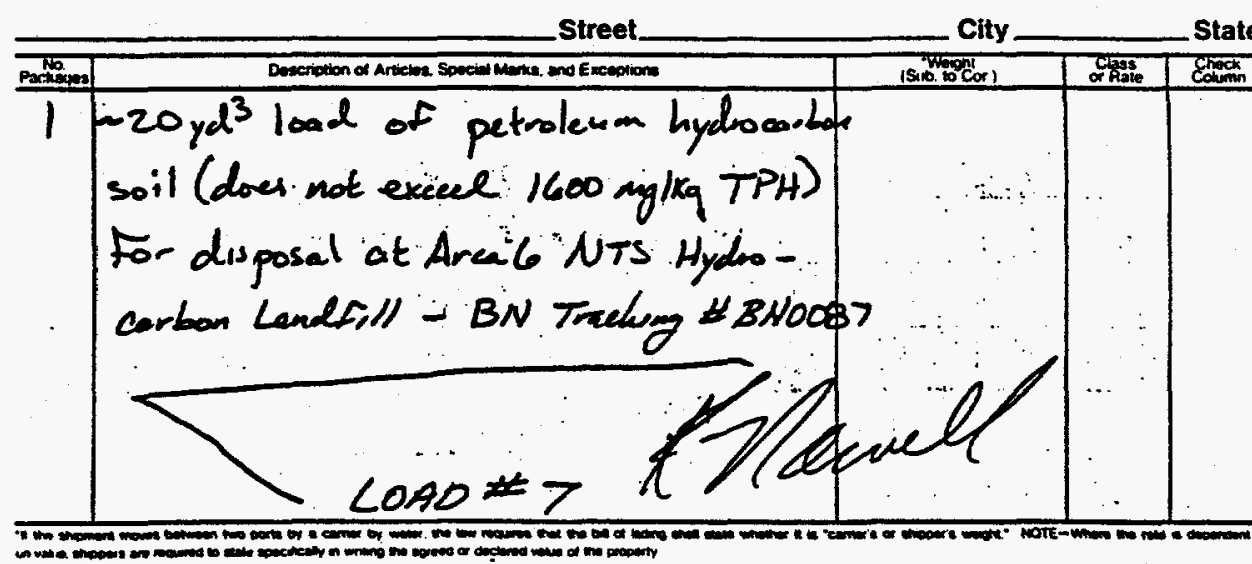

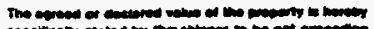

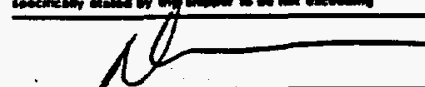

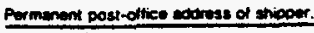

Shipper, Per

$\infty$

RiLmelicane C. Q. A. chante f Shipper to be agid by 1 consigas Sibject to Section 7 of concitions. * consioner withorit necaurse on tro con. ivor. the consogion shall sion the bollowng selument:

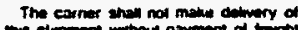
wint all other tew wh chimoen.

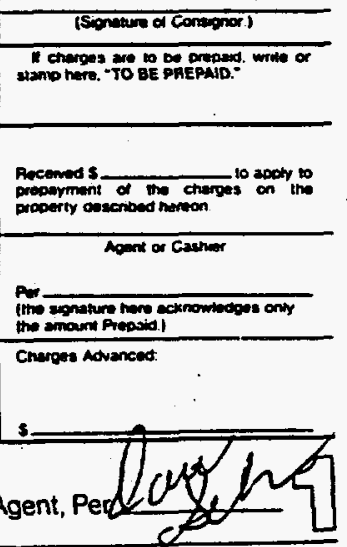

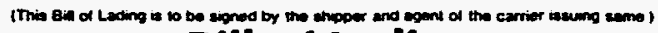




\section{State OF NEVADA}

PUBLIC WEIGHMASTEh'S CER IIFICATE OF WEIGHT AND MEASURE

This is te certity. That the following - described marchandise was woighed by a Publi

Weighmaster as prescribed by the Public Weighmaster Law. NRS. Chapter 582

103630 LE $7: 00$ A $8-26-97$ Gross

rane.

MET'

635004

\section{SMEDLEY'S}

WSS RENO HICHWAT MONE (MOI) OZ3 $\$ S 00$ FALLON. NEVADABSON

Belehter

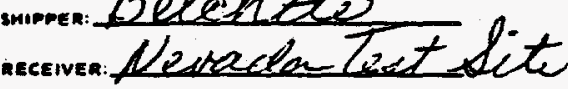

antomens $\frac{8 / 26 / 92}{B \text { efohele }}$

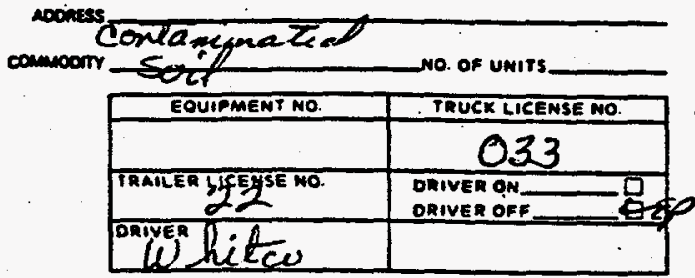

SMEDLEY
USLIC WEIGMASTE

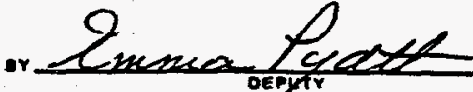

J.H. sMitrien - ownen

$4,1557 / 28620$

F romens cumess rooms

UNIFORM STRAIGHT BILL OF LADING Original-Not Negotiable-Domestic

Shipper's e

Carrier

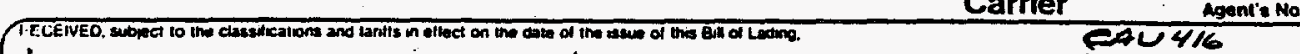

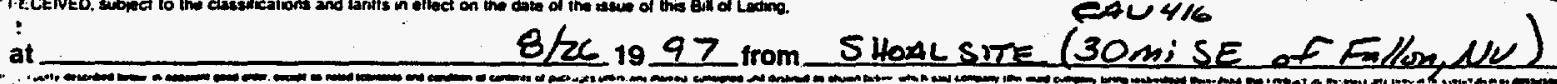
$\therefore$ (n)

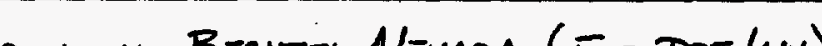

(Meill or atreet addrass of consionen-for purposes of notulication only.)

Consigned to BECHTEL NevaDA (FE DOE/NN)

Destination NEUADA TESTSITE

State of

NU Zip code County of NYE

Routing Delivering Mclane

Vehicle Collect On Delivery

or Car Initial ___ No. and remit to:
(1)

Street

i. Kinges

1 - $20 y d^{3}$ lood of petroleum hydrocostoon soil (does not excece $1600 \mathrm{mg} / \mathrm{kg} T$ TP)

for disposal at NTs Area 6 Hydoould Landinll - BN Trechoing $48 N-0087$
City

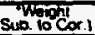

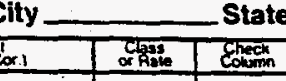

\section{$\angle \cos 8$}

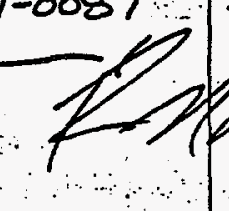

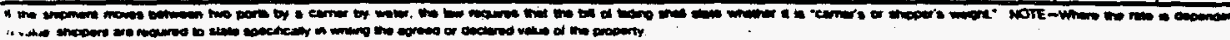

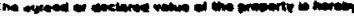

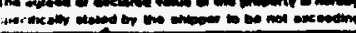

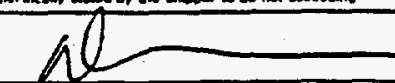

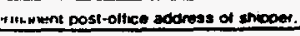

C. 0. D. charpo f Stipper le te gid by $\{$ Consignas

Subioct to Section 7 at conculons it this shioment it to to downowed to the consioner without necoces on tha con.

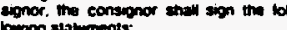

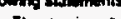
The cartier shall not meke detory of ind all other bowlut charoes. (Shonature of Consonor)

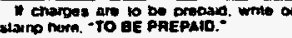

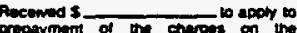
property desconbed thereon.

$$
\text { Mom or Cachior }
$$

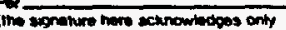
ou amouns Prepad Charges novances: 


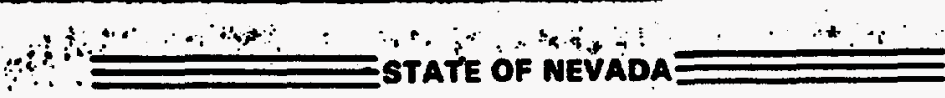

PUQLIC WEGMMASTEA'S CEATIFICATE OF WEIGHT ANO MEASURE

This to to certify, That the following - doscribed murchandise was woighed by a Public

Weighmaster as preseribed by the Public Weighmaster Law, NAS. Chapter 582 95890 LA $6: 49 A \quad 8-2 S-87$

21980

rise

60,90013

\section{SMEDLEY'S}

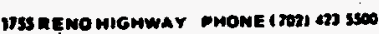
FALLON. MEVAOA WMOA

Belchtle

minem: Beverenada Test site
8. 126197 arromesnes Belcht/p
No. 68198

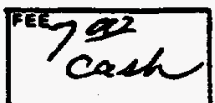

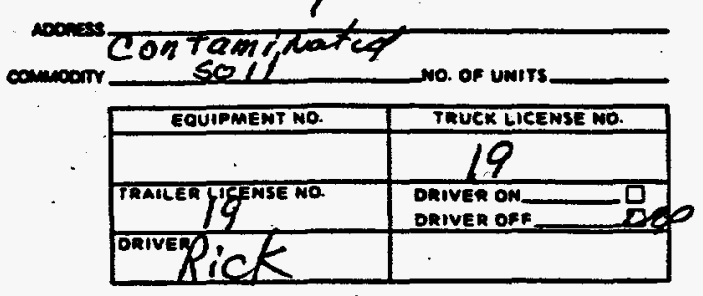

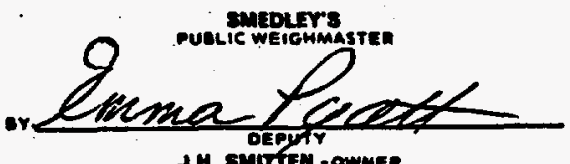

054557/29020

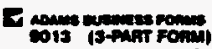

UNIFORM STPAIGHT BILL OF LADING OriginaI-Not Negotiable-Domestic

snipoer's :

Carrier

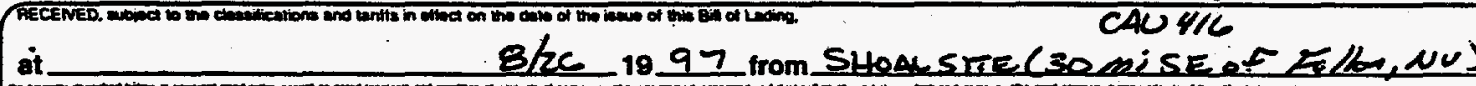
IN

Consigned to Becurel Nevasa (For Doe/Nu)

Destination NENADA TEST STrE

State of Nu Zip Code

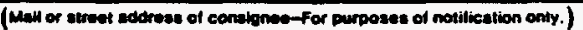

Routing Delivering Vehicle Collect On Delivery

$\$$ and remit to:

County of NYE Carrier MClasue or Car Initial

No.

Street

\begin{tabular}{|c|c|c|c|c|}
\hline Pateon & 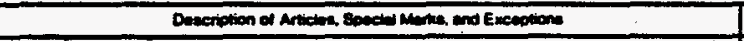 & (Seb $00 \mathrm{cos})$. & orpan & \\
\hline $\begin{array}{l}\vdots \\
\vdots \\
\vdots\end{array}$ & 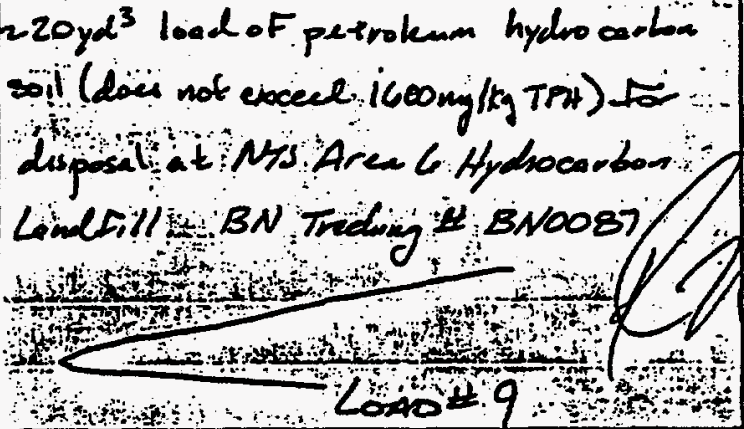 & Oed & 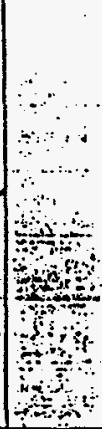 & 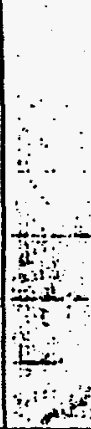 \\
\hline
\end{tabular}
Sibiect is Saction 7 of conoitions a

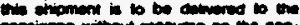

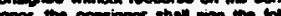

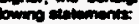
The earrier min not mane avery of

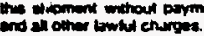

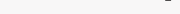




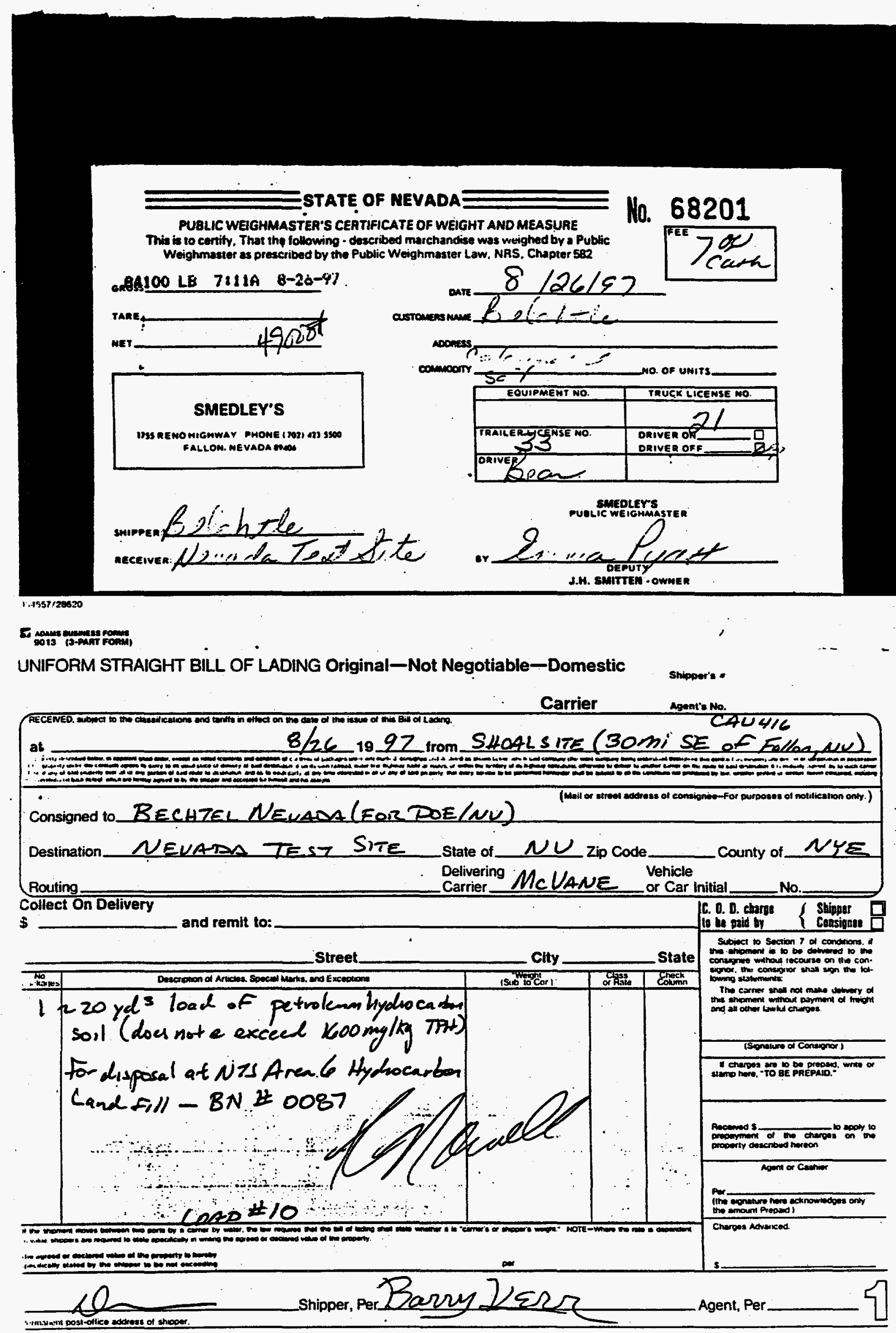




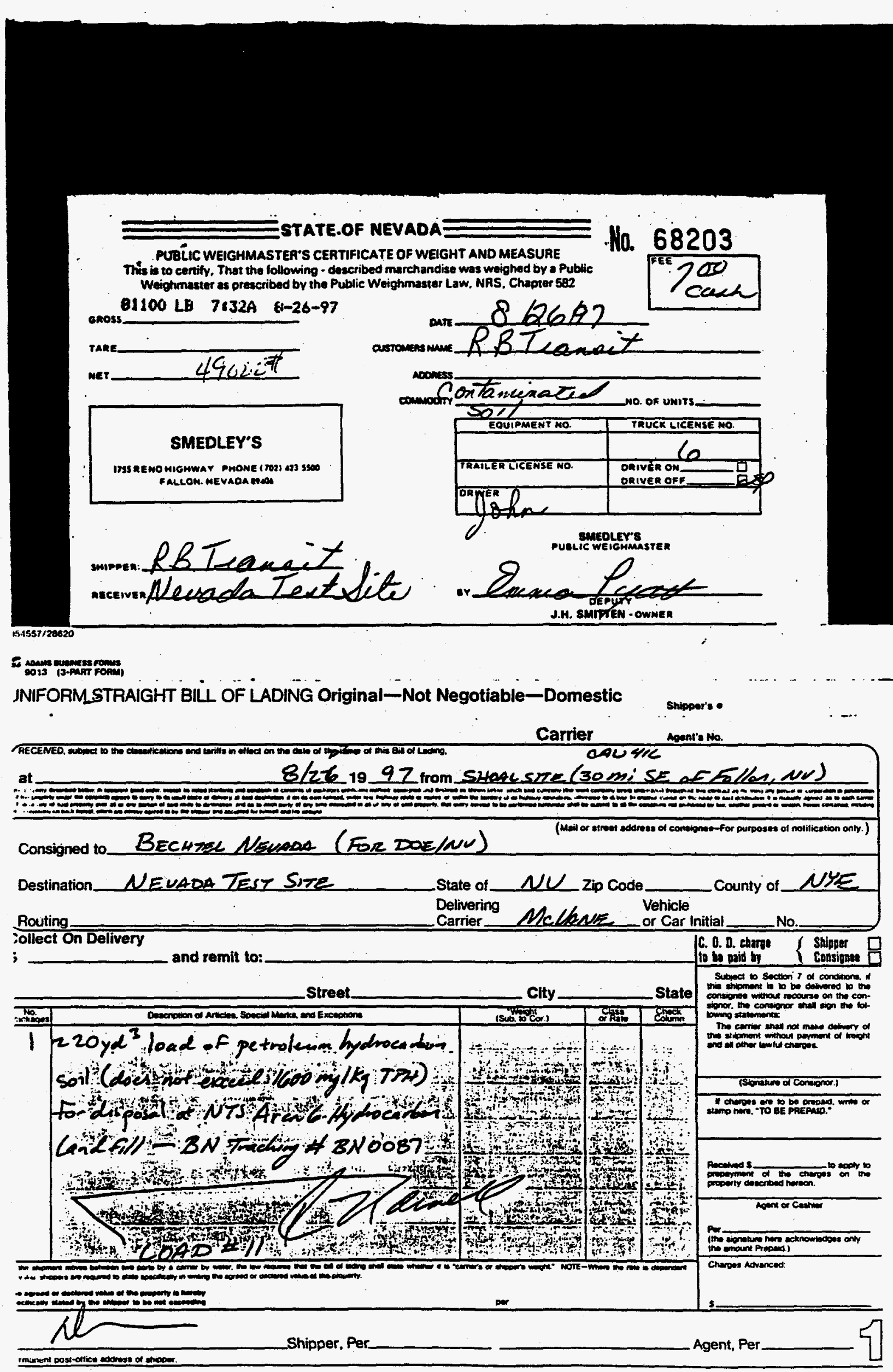




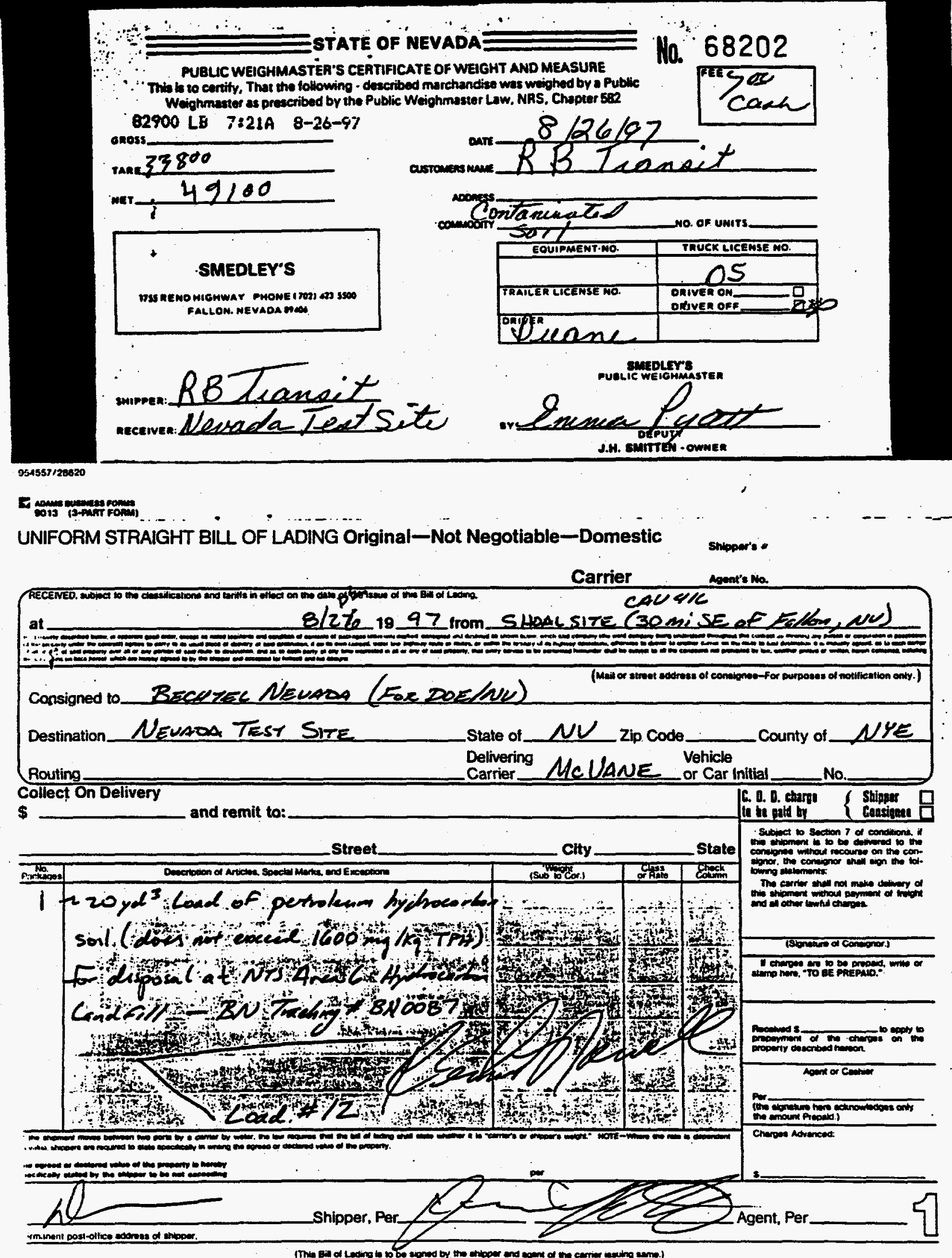




\section{APPENDIX D}

\section{LABORATORY ANALYTICAL RESULTS MUD PIT VERIFICATION SAMPLES}


CLIENT: Intemational Technology Corporation 4330 S. Valley View 1114

Las Vegas, Nevada 89103

ATTN: Kurt Schmidt

PROJECT NAME: Project Shoul

PROJECT NUMBER: $\mathbf{7 7 1 0 6 0 . 0 7 . 0 3}$

PURCHASE ORDER: 081597BC

NEL ID: R9708050-0109

Atmehed are the analytical results for samples in sugport of the above referenced project.

Samples sobmitted for this project vere not sampled by NEL Laboratories. Samples were received by NEL in good condition, under chain of castody on 8/19/97, and analyzed as received.

Where applieable we have inchuded the following quality control data; a method blank, used to document contamination resulting from the analytical process, a Laboratory Control Spike (LCS), used to document laboratory performance, and Surrogates, organic compounds which are similar to the target analyte(s) in chemical composition and behavior in the analytical process, but which are not normally found in envirommenal samples.

Surrogate results were determined following a new ealibration curve on 8/23/97. TPH results were not effected.

Should you have any questions or comments, please feel free to contact our Client Services deperment (702) 348-2522.
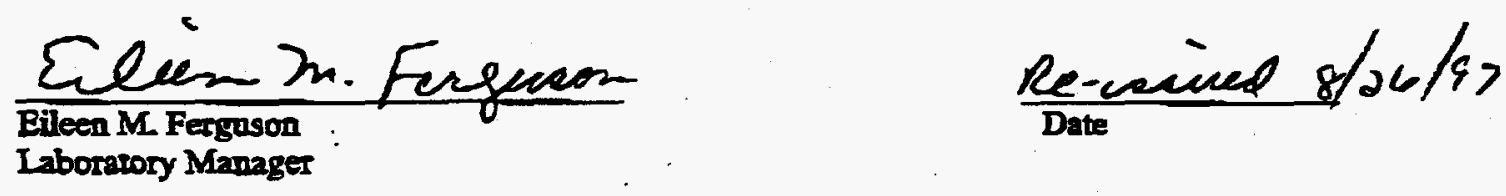


\section{NEL LABORATORIES}

CLIENT: International Technology Corporation PROJECI NAME:Project Shoal

PROJECT NUMBER: 771060.07 .03

ANALYST:RA

METHOD: TOTAI EXTRACTABLE PETROLEUM FYDROCARBONS BY EPA 8015M, September 1994

SAMPLE MATRIX: SOIL

\begin{tabular}{|c|c|c|c|c|c|c|c|}
\hline CLTENTID & $\begin{array}{c}\text { DATE } \\
\text { SAMPITD }\end{array}$ & NQL I & $\begin{array}{c}\text { RESULTS } \\
\text { mg/kg }\end{array}$ & $\begin{array}{l}\text { REPORTIIG } \\
\text { IMMII }\end{array}$ & $\begin{array}{l}\text { Surrogate } \\
\text { Rexpredr }\end{array}$ & EXIRACTUD & ANALYKATD \\
\hline PSA-V01 & $8 / 19 / 97$ & $\begin{array}{c}\text { R9708050-01 } \\
C_{10-24} \\
C_{24}\end{array}$ & $\begin{array}{l}21 \\
53\end{array}$ & $\begin{array}{l}15 \mathrm{mg} / \mathrm{kg} \\
15 \mathrm{mg} / \mathrm{kg}\end{array}$ & $104 \%$ & $8 / 20 / 97$ & $8 / 22 / 97$ \\
\hline PSA-V02 & $8 / 19 / 97$ & $\begin{array}{c}R 9708050-02 \\
C_{1020} \\
>C_{26}\end{array}$ & ND & $\begin{array}{l}15 \mathrm{mg} / \mathrm{kg} \\
15 \mathrm{mg} / \mathrm{kg}\end{array}$ & $79 \%$ & $8 / 20 / 97$ & $8 / 22 / 97$ \\
\hline PSA-V03 & $8 / 19 / 97$ & $\begin{array}{c}R 9708050-03 \\
C_{10-21} \\
>C_{24}\end{array}$ & $\begin{array}{c}62 \\
120\end{array}$ & $\begin{array}{l}15 \text { mg/kg } \\
15 \text { mg/kg }\end{array}$ & $115 \%$ & $8 / 20 / 97$ & $8 / 21 / 97$ \\
\hline
\end{tabular}

"Surogate used was n-triacontane, acceprance limits 65-135\%.

QUALITY CONTROL DATA (Total for Diesel Range):

\begin{tabular}{|c|c|c|c|c|}
\hline Sample ID & Result & Accentable Ranges & $\frac{\text { Surropate }}{\text { Becorer }}$ & Acegntab \\
\hline $\begin{array}{l}\text { Method Blank, 082097-E2-BLR } \\
\text { LCS, 082097-E2-LCS } \\
\text { MS, R9708050-06 MS } \\
\text { MSD, R9708050-06 MSD }\end{array}$ & $\begin{array}{l}\text { ND } \\
85 \% \\
76 \% \\
79 \%\end{array}$ & $\begin{array}{l}<15 \mathrm{mg} / \mathrm{kg} \\
65-135 \% \\
65-135 \% \\
65-135 \%\end{array}$ & $\begin{array}{l}92 \% \\
107 \% \\
107 \% \\
105 \% \%\end{array}$ & $\begin{array}{l}65-135 \% \\
65-135 \% \\
65-135 \% \\
65-135 \%\end{array}$ \\
\hline
\end{tabular}

ND - Not Detected

This report shall not be reproduced except in full, without the written approvel of the laboratory. 


\section{NEL LABORATORIES}

CLIENT: International Technology Cosporation

PROJECT NAME:Project Shoal

PROJECT NUMBER: 771060.07.03

ANALYST:RA

METHOD: TOTAL EXTRACTABLE PETROLEUM HYDROCARBONS BY EPA 8015M, September 1994

SAMPLE MATRDX: SOIL

\begin{tabular}{|c|c|c|c|c|c|c|c|}
\hline CLIENTII & $\begin{array}{c}\text { DATE } \\
\text { SAMPLED }\end{array}$ & NYLID & $\begin{array}{l}\text { RESULTS } \\
\text { mefke }\end{array}$ & $\begin{array}{l}\text { REPORTING } \\
\text { LMUT }\end{array}$ & $\begin{array}{l}\text { Surrogate } \\
\text { Resoverat }\end{array}$ & EXTURACTUD & ANALYTAD \\
\hline PSA-V04 & $8 / 19 / 97$ & $\begin{array}{c}\text { R9708050-04 } \\
C_{10-24} \\
>_{24}\end{array}$ & $\begin{array}{c}38 \\
130\end{array}$ & $\begin{array}{l}15 \mathrm{mg} / \mathrm{kg} \\
15 \mathrm{mg} / \mathrm{kg}\end{array}$ & $91 \%$ & $8 / 20 / 97$ & $8 / 21 / 97$ \\
\hline PSA-V05 & $8 / 19 / 97$ & $\begin{array}{c}R 9708050-05 \\
C_{10-24} \\
>C_{24}\end{array}$ & $\begin{array}{c}44 \\
170\end{array}$ & $\begin{array}{l}15 \mathrm{mg} / \mathrm{kg} \\
15 \mathrm{mg} / \mathrm{kg}\end{array}$ & $119 \%$ & $8 / 20 / 97$ & $8 / 21 / 97$ \\
\hline PSA-V06 & $8 / 19 / 97$ & $\begin{array}{c}R 9708050-06 \\
C_{10-24} \\
>C_{24}\end{array}$ & $\begin{array}{l}51 \\
130\end{array}$ & $\begin{array}{l}15 \mathrm{mg} / \mathrm{kg} \\
15 \mathrm{mg} / \mathrm{kg}\end{array}$ & $108 \%$ & $8 / 20 / 97$ & $8 / 22 / 97$ \\
\hline PSA-V06 & $8 / 19 / 97$ & $\begin{array}{c}\text { R9708050-06 } \\
\text { DUPP } \\
C_{1024} \\
>C_{28}\end{array}$ & $\begin{array}{c}47 \\
120\end{array}$ & $\begin{array}{l}15 \mathrm{mg} / \mathrm{kg} \\
15 \mathrm{mg} / \mathrm{kg}\end{array}$ & $97 \%$ & $8 / 20 / 97$ & $8 / 22 / 97$ \\
\hline
\end{tabular}

- Surrogate used was n-triacontane, acceptrace limits 65-135\%.

QUALITY CONTROL DATA (Total for Dierel Ronge):

Sample $\mathbf{~ R}$

Method Blank, 082097-E2-BLR

LCS, 082097-E2-LCS

MS, R9708050-06 MS

MSD, R9708050-06 MSD
Resnit

ND

$85 \%$

$76 \%$

$79 \%$
Acceptable Range

$<15$ mp/kg
$65-135 \%$
$65-135 \%$

$65-135 \%$
Surrogete Recorerr

$92 \%$

$107 \%$

$107 \%$

$105 \%$
Acceotoble Range

65-135\%

$65-135 \%$

$65-135 \%$

$65-135 \%$

ND - Not Detected

This report shall not be reproduced exept in finl, without the wrizen approval of the laboratory. 


\section{NEL LABORATORIES}

CLIENT: Intermational Technology Corporarion PROJECT NAME:Project Shoal

PROJECT NUMBER: 771060.07 .03

ANALYST:RA

METHOD: TOTAL EXTRACTABLE PETROLEUM HYDROCARBONS BY EPA 8015M, September 1994

SAMPLE MATRX: SOIL

\begin{tabular}{|c|c|c|c|c|c|c|}
\hline ChITNT ID & $\begin{array}{c}\text { DATE } \\
\text { SAMPLED }\end{array}$ & NMLID & $\begin{array}{c}\text { RESULTS } \\
\text { ma/kg }\end{array}$ & $\begin{array}{l}\text { REPORTING } \\
\text { LDMII }\end{array}$ & $\begin{array}{l}\text { Surrogate } \\
\text { Recovery }\end{array}$ & EXIPACITD \\
\hline PSA-V07 & $8 / 19 / 97$ & $\begin{array}{c}R 9708050-07 \\
C_{20-24} \\
>C_{24}\end{array}$ & $\begin{array}{l}33 \\
92\end{array}$ & $\begin{array}{l}15 \mathrm{mg} / \mathrm{kg} \\
15 \mathrm{mg} / \mathrm{kg}\end{array}$ & $115 \%$ & $8 / 20 / 97$ \\
\hline PSA-V08 & $8 / 19 / 97$ & $\begin{array}{c}R 9708050-08 \\
C_{1024} \\
>C_{24}\end{array}$ & $\begin{array}{l}\text { ND } \\
\text { ND }\end{array}$ & $\begin{array}{l}15 \mathrm{mg} / \mathrm{kg} \\
15 \mathrm{mg} / \mathrm{kg}\end{array}$ & $76 \%$ & $8 / 20 / 97$ \\
\hline PSA-V09 & $8 / 19 / 97$ & $\begin{array}{c}R 9708050-09 \\
C_{10.26} \\
>C_{22}\end{array}$ & $\begin{array}{l}48 \\
110\end{array}$ & $\begin{array}{l}15 \mathrm{mg} / \mathrm{kg} \\
15 \mathrm{mg} / \mathrm{kg}\end{array}$ & $109 \%$ & $8 / 20 / 97$ \\
\hline
\end{tabular}

'Surrogate used was n-triacontane, acceptance limits $65-135 \%$. .

QUALITY CONTROL DATA (Total for Diesel Renge):

\begin{tabular}{|c|c|c|c|}
\hline Sample ID & Resnit & Accentable Ronge & $\begin{array}{l}\text { Sirrogate } \\
\text { Becover. }\end{array}$ \\
\hline $\begin{array}{l}\text { Method Blank, 082097-E2-BLR } \\
\text { LCS, 082097-E2-LCS } \\
\text { MS, R9708050-06 MS } \\
\text { MSD, R9708050-06 MSD }\end{array}$ & $\begin{array}{l}\text { ND } \\
85 \% \\
76 \% \\
79 \%\end{array}$ & $\begin{array}{l}<15 \mathrm{mg} / \mathrm{kg} \\
65-135 \% \\
65-135 \% \\
65-135 \%\end{array}$ & $\begin{array}{l}92 \% \\
107 \% \\
107 \% \\
105 \%\end{array}$ \\
\hline
\end{tabular}

ND - Not Dereeted

This report shall not be reproduced except in full, without the wrinen approval of the laboratory. 


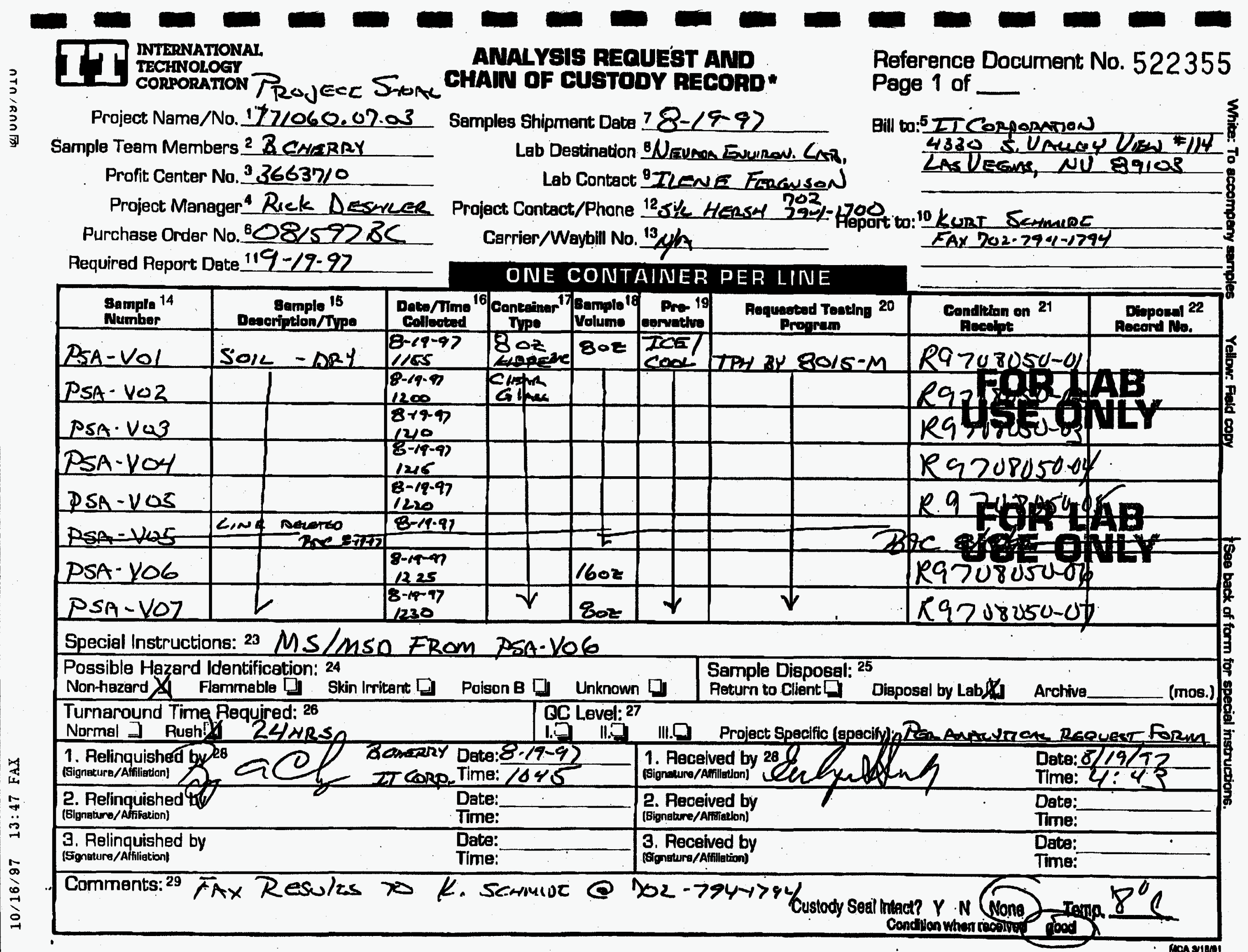


NTERNATIONAL

Project Name Rrajece Sroar
ANALYSIS REQUEST AND CHAIN OF CUSTODY RECORD (cont.)*

Project No. $72 / 00002030000$
Reference Document No. ${ }^{30} 522355$ Page_2 of 2

Samples Shipment Dete $8-19-97$ ONE CONTAINER PER LINE

\begin{tabular}{|c|c|c|c|c|c|c|c|c|}
\hline $\begin{array}{l}\text { Samplo } 14 \\
\text { Number }\end{array}$ & $\begin{array}{l}\text { samplo } 15 \\
\text { criptipen }\end{array}$ & 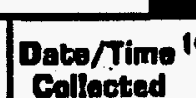 & sont & 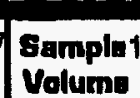 & $\begin{array}{c}\text { Preal9 } \\
\text { oryeto }\end{array}$ & Roquestad Trenting 20 & 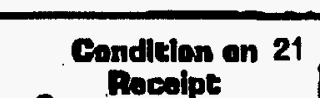 & 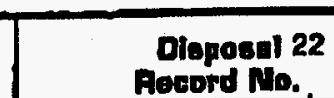 \\
\hline BSA-VOB & Sore - D pry & $1+235$ & 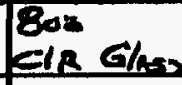 & $80:$ & Eer & $7043,805-m$ & K9 & \\
\hline PSA-VOG & $\operatorname{Sen} D_{R Y}^{\prime}$ & $\begin{array}{l}8-17-49 \\
1248\end{array}$ & 1 & $L$ & L & $L$ & RGPOA & \\
\hline$\angle A_{s t} \angle$ & NEE BAC & $8-19-$ & 22 & 7 & & & USE & LY \\
\hline & & & & Z & & & & \\
\hline & & & & & & & & \\
\hline & & & & & & & & LAB \\
\hline & & & & & & & & \\
\hline & & & & & & & & \\
\hline & & Z & & & & & & \\
\hline & & & & & & & & \\
\hline & 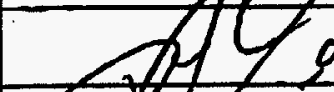 & & & & & & $\mathbf{F O}$ & $\angle A B$ \\
\hline & $121^{19}$ & & & & & & USE & JULY \\
\hline & $11 / 8$ & & & & & & & tear \\
\hline & & & & & & & -1 & 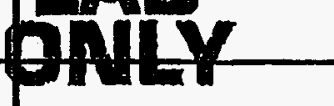 \\
\hline & & & & & & & & AR \\
\hline & & & & $\because$ & & & USE & DINLY \\
\hline & & & & & & & & \\
\hline & & & & & & $=$ & & \\
\hline
\end{tabular}


CIIIENT: Intemational Technology Corporation 4330 S. Valley View \#114

Las Vegas, Nevada 89103

ATIN: Kurt Schmidt

PROJECT NAME: Project Shoal

PROJECT NUMBER: 771060.07 .03

PURCHASE ORDER: 081597BC

NEL D: R9708065-01/05

Attached are the amalytical results for samples in support of the above referenced project.

Samples submitwed for this project were not sampled by NEL Labomiories. Sarmples were received by NEI in good condition, under chain of eustody on 8/25/97, and analyzed as received.

Where applicable we have incheded the following quality control datz; a method blank, used to document contamination resulting from the analytical process, a Laboratary Control Spike (LCS), used to document laboratory performance, and Swrogates, organic compounds which are similar to the target analyte(s) in chemical composition and behavior in the analytical process, but which are not nommally found in enviromental semples.

Should you have any questions or comments, please feel free to conmet our Client Services deparment (702) 348-2522.
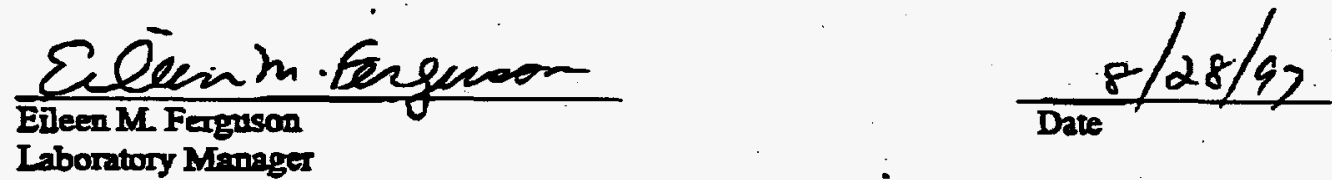


\section{NEL LABORATORIES}

CLIENT: International Technology Corporation PROJECT NAME:Project Shoal

PROJECT NUMBER: 771060.07.03

ANALYST:RA

METHOD: TOTAL EXTRACTABIE PETROLEUM AXDROCARBONS BY EPA 8015M, September 1994

SAMPLE MATRX: SOIL

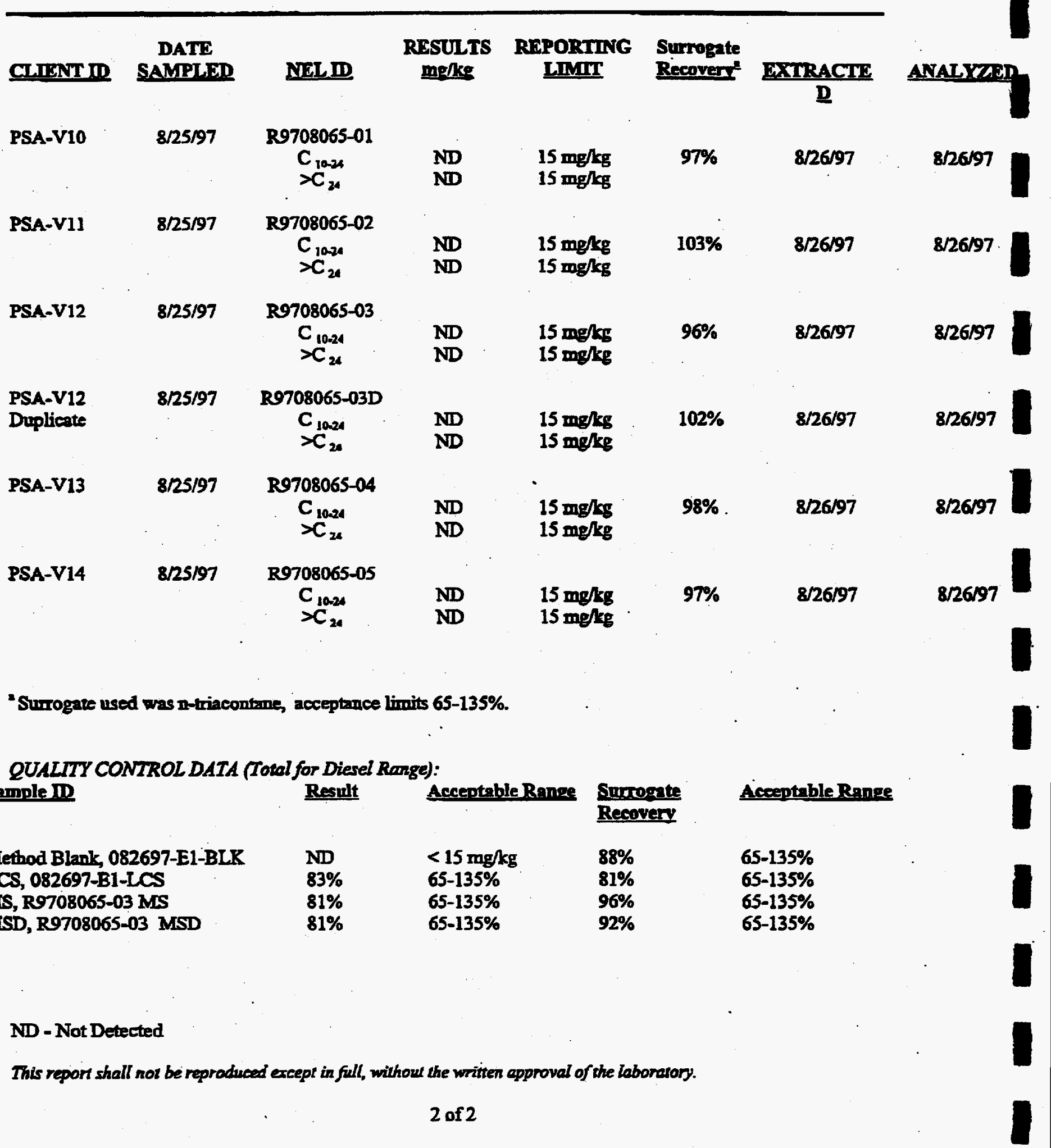




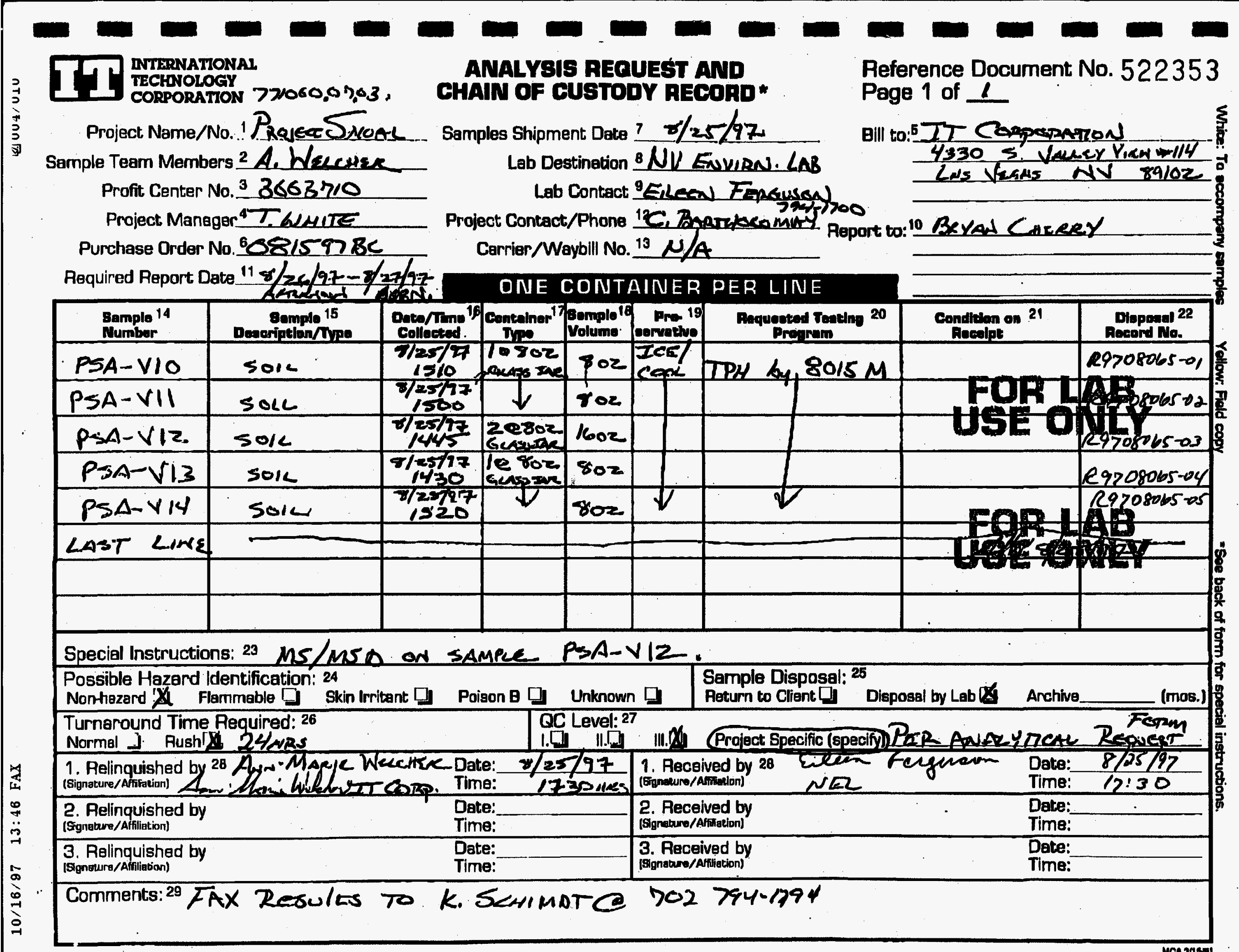




\section{DISTRIBUTION LIST}


Bureau of Federal Facilities

Division of Environmental Protection

333 W. Nye Lane, Room 13B

Carson City, NV 89706-0866

P. J. Liebendorfer

D. A. Garrepy

U.S. Department of Energy, Nevada Operations Office

P. O. Box 98518,505

Las Vegas, NV 89193-8518

S. D. Bonnell

U.S. Department of Energy, Nevada Operations Office P. O. Box 98518,505

Las Vegas, NV 89193-8518

Monica A. Sanchez

Peter A. Sanders

Public Reading Room

Technical Information Resource Center

U. S. Department of Energy,

Office of Scientific and Technical Information

P. O. Box 62

Oak Ridge, TN 37831

Bechtel Nevada

P. O. Box 98521 , M/S NLV008

Las Vegas, NV 89193-8521

Correspondence Control

D. K. Cowser

D. D. Madsen

K. A. Mobley

S. J. Nacht 


\section{DISTRIBUTION LIST (continued)}

\section{Uncontrolled Copies}

\section{IT Corporation}

P. O. Box 93838, M/S 439

Las Vegas, NV 89193-3838

R. Deshler

T. White 